U.S. Department of Energy

Idaho Operations Office

\title{
FY 2013 INL Site Sustainability Plan with the FY 2012 Annual Report
}

December 2012 
(This Page Intentionally Left Blank) 
DOE/ID-11383

Revision 4

\section{FY 2013 INL Site Sustainability Plan with the FY 2012 Annual Report}

December 2012

Prepared for the

U.S. Department of Energy

DOE Idaho Operations Office 
(This Page Intentionally Left Blank) 


\title{
FY 2013 INL Site Sustainability Plan with the FY 2012 Annual Report
}

\author{
DOE/ID-11383 \\ Revision 4
}

December 2012
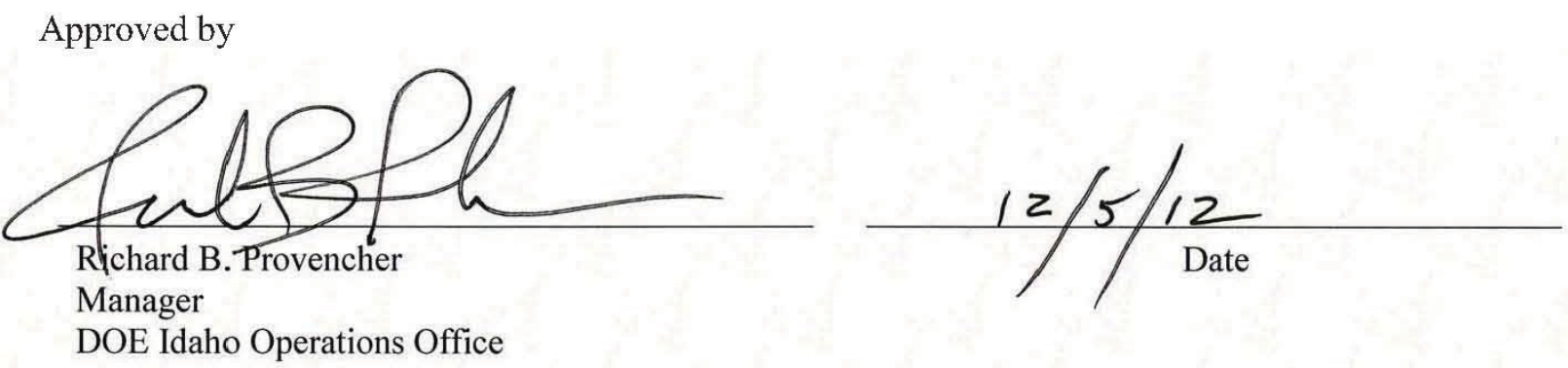

DOE Idaho Operations Office 
(This Page Intentionally Left Blank) 
FY 2013 INL Site Sustainability Plan with the FY 2012 Annual Report

DOE/ID-11383

Revision 4

December 2012

Approved by

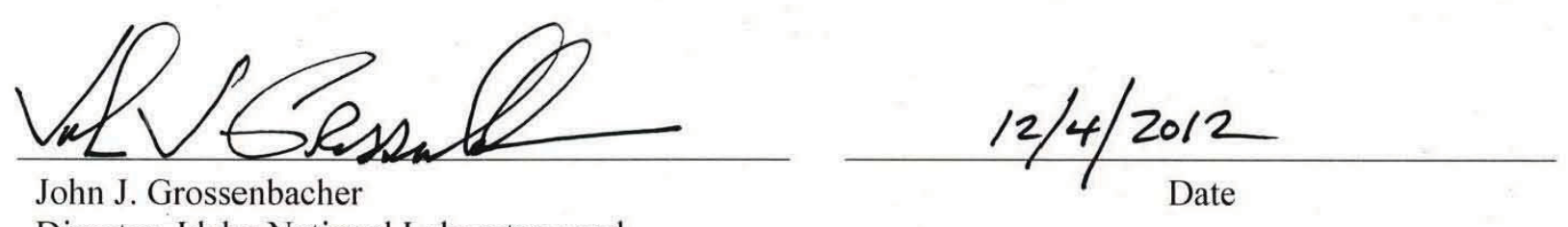

Director, Idaho National Laboratory and

President, Battelle Energy Alliance, LLC 
(This Page Intentionally Left Blank) 


\title{
FY 2013 INL Site Sustainability Plan with the FY 2012 Annual Report
}

\author{
DOE/ID-11383 \\ Revision 4
}

December 2012

Approved by

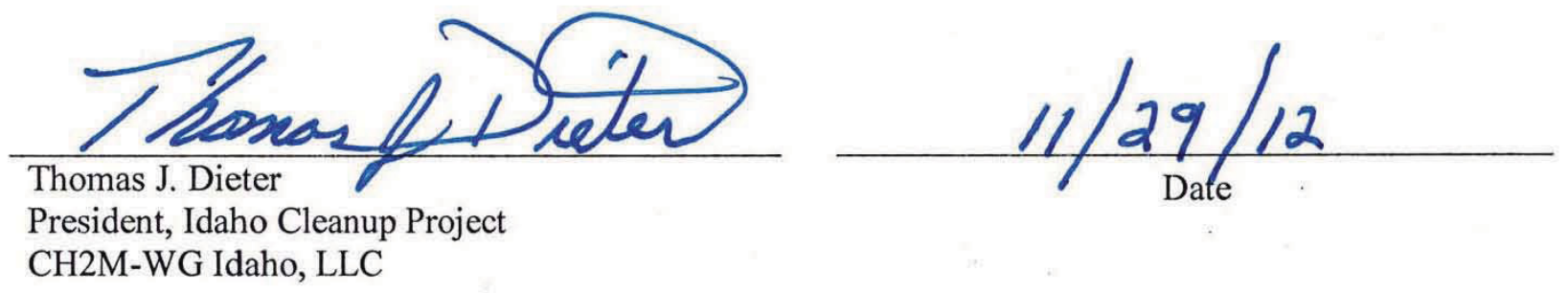


(This Page Intentionally Left Blank) 


\title{
FY 2013 INL Site Sustainability Plan with the FY 2012 Annual Report
}

\author{
DOE/ID-11383
}

Revision 4

December 2012

Approved by

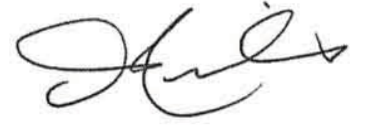

Danny Nichols

President and Project Manager

Idaho Treatment Group, LLC

Advanced Mixed Waste Treatment Project

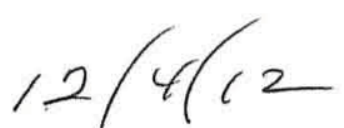

Date 
(This Page Intentionally Left Blank) 


\section{EXECUTIVE SUMMARY}

Clean energy and sustainability have long been at the core of the mission of the U.S. Department of Energy (DOE) and are reinforced in Executive Order (EO) 13514, Federal Leadership in Environmental, Energy, and Economic Performance, and Executive Order 13423, Strengthening Federal Environmental, Energy, and Transportation Management, DOE has articulated its key strategies and goals in its 2012 Strategic Sustainability Performance Plan (SSPP). The Idaho National Laboratory (INL) Site incorporates these strategies through this plan.

DOE Order 436.1, Departmental Sustainability, provides requirements and assigns responsibilities for managing sustainability within DOE to ensure that missions are carried out in a sustainable manner, to institute wholesale cultural change to factor sustainability and greenhouse gas (GHG) reductions into all DOE decisions, and to ensure that DOE achieves the sustainability goals established in its SSPP. DOE Order 436.1 and the SSPP require that DOE sites commit appropriate personnel resources, establish a financing plan that prioritizes the use of lifecycle cost-effective private sector financing and optimizes the application of appropriations and budgeted funds, and establish specific performance measures and deliverables designed to achieve the listed requirements.

The "FY 2013 INL Site Sustainability Plan with the FY 2012 Annual Report," hereafter referred to as the Plan, was developed according to the narrative requirements from the "Guidance for the FY 2012 DOE Site Sustainability Plans" issued on August 10, 2012. This Plan contains strategies and activities that will lead to continual GHG, energy, water, and transportation fuels efficiency to move the INL Site towards meeting the goals and requirements of the SSPP, EOs 13514 and 13423, and DOE Order 436.1 before the end of Fiscal Year (FY) 2020. The Plan summarizes energy and fuel use reporting requirements and references criteria for performing sustainable design. Plan requirements are integrated into each of the INL Site contractor's Integrated Safety Management Systems (ISMS) and Environmental Management Systems (EMS). Finally, Sustainability Program directives based on this Plan are integrated into the INL Ten-Year Site Plan (TYSP) and operations and acquisition systems.

For the purposes of this document, the "INL Site" is considered all operating contractors and the Department of Energy Idaho Operations Office (DOE-ID), and includes the industrial complexes located west of Idaho Falls and the Idaho Falls buildings. INL is considered to be those facilities operated by Battelle Energy Alliance, LLC (BEA). The Advanced Mixed Waste Treatment Project (AMWTP) and Idaho Cleanup Project (ICP) are referred to by their noted acronyms and include all facilities under their individual responsibility.

This DOE-ID INL Site document serves as the overall INL Site Sustainability Plan. It is supplemented by individual contractor plans and strategies as needed. Updates to the Plan are anticipated annually with added specificity as projects are developed and requirements change. This Plan encompasses all contractors and activities at the INL Site under the control of DOE-ID. The operations and activities of the Naval Reactors Facility (NRF), located on the INL Site, are specifically excluded from this Plan.

The Environmental Management mission assumptions for this Plan include the cessation of AMWTP operations and AMWTP facilities achieving a cold, dark, and dry status by FY 2018.

The intent of this Plan is to provide the overall Sustainability strategy for the INL Site during FY 2013. Integral to this Plan is the FY 2012 Annual Report. The Annual Report data for FY 2012 are provided on the Consolidated Energy Data Report (CEDR) that is included as Appendix C.

DOE-ID and the INL Site contractors use their existing EMS to establish goals, track, and review progress towards meeting the energy and water efficiency, greenhouse gas reduction, and renewable energy goals. INL Site contractors will leverage all available sources of funding including Strategic Investment Funding (SIF) and alternative funding programs such as Energy Savings Performance 
Contracts (ESPC) and Utility Energy Services Contracts (UESC) to implement energy and water reduction projects. Projects identified to date are included on the Conservation Measures worksheet of the CEDR. The INL Site will leverage utility incentive programs to the maximum extent available.

The INL Site spent nearly $\$ 12.6 \mathrm{M}$ in FY 2012 for facility, process, and equipment energy. Of this total, $\$ 11.9 \mathrm{M}$ was spent for building energy, $\$ 1.06 \mathrm{M}$ was spent for process energy, and $\$ 696 \mathrm{~K}$ was spent on equipment fuel. The INL Site used over 858.2 billion Btu of energy and 859.0 million gallons of water. Transportation fuel use across the INL Site in FY 2012 totaled 1,001,042 gallons of various types of fuels. The fleet is composed of light-duty vehicles fueled by gasoline and E-85. Heavy-duty vehicles include over-the-road buses fueled by diesel and biodiesel, and a complex assortment of trucks and equipment. Typically, 9.5 million miles are driven annually and over 50,000 hours are logged on heavy equipment.

Tables ES-1and ES-2 and Figure ES-1 summarize the Annual Report data and provide an FY 2012 status of the DOE SSPP goals. The FY 2012 goals in the graph are the trend point of where the INL Site should be after FY 2012 to remain on track to meet the overall goals by the end of FY 2020. Discussion of the FY 2012 status and planned FY 2013 actions are found in the body of this Plan.

Table ES-1. DOE Sustainability Performance Office (SPO) Key Milestones Status

\begin{tabular}{|l|l|c|}
\hline $\begin{array}{c}\text { SPO } \\
\text { Goal }\end{array}$ & \multicolumn{1}{|c|}{ DOE Goal } & \begin{tabular}{c}
$|c|$ \\
\multicolumn{1}{|c|}{ FY 2012 } \\
Status
\end{tabular} \\
\hline 3a. & Reduce Scopes 1 and 2 Emissions by 1\% (15\% cumulative from FY 2008) & -20.3 \\
\hline 3b. & Reduce Scope 3 Emissions by 1\% (3\% cumulative from FY 2008) & $-7.3 \%$ \\
\hline 3c. & Reduce Energy Intensity by 21\% & $-13.8 \%$ \\
\hline 3d. & Meter 90\% of the Site's Total Electricity & $49 \%$ \\
\hline 3e. & Meter 25\% of the Site's Total Natural Gas by 2015 & $100 \%$ \\
\hline 3f. & Assess 100\% of Facilities for Energy and Water Measures & $75 \%$ \\
\hline 3g. & Maintain 5\% Renewable Energy as Percent of Facility Energy Use & $9.9 \%$ \\
\hline 3h. & Reduce Water Use by 2\% (10\% cumulative from FY 2007) & $-11.4 \%$ \\
\hline 3i & Reduce Petroleum Use by 2\% (14\% cumulative from FY 2005) & $-20.3 \%$ \\
\hline 3j. & Increase Alternative Fuel Use (61\% cumulative from FY 2005) & $154 \%$ \\
\hline 3k. & Reduce Fleet by 15\% & $35 \%$ \\
\hline 31. & $9 \%$ of Building Stock meets Federal Guiding Principles for HPSB & $2 \%$ \\
\hline
\end{tabular}

Table ES-2. Sustainability Goals Discussion.

\begin{tabular}{|l|l|l|l|l|}
\hline $\begin{array}{l}\text { SSPP } \\
\text { Goal }\end{array}$ & \multicolumn{1}{|c|}{ DOE Goal } & \multicolumn{1}{|c|}{ Performance Status } & \multicolumn{1}{c|}{$\begin{array}{c}\text { Planned Actions and } \\
\text { Contribution }\end{array}$} & $\begin{array}{c}\text { Risk of } \\
\text { Non- } \\
\text { Attainment }\end{array}$ \\
\hline 1.1 & $\begin{array}{l}28 \% \text { Scope 1 \& } \\
2 \text { GHG reduction } \\
\text { by FY 2020 from } \\
\text { a FY 2008 } \\
\text { baseline }\end{array}$ & $\begin{array}{l}\text { The INL Site combined } \\
\text { Scope 1 \& 2 GHG } \\
\text { emissions are down 20.3\% } \\
\text { from the FY 2008 baseline. }\end{array}$ & $\begin{array}{l}\text { GHG emission reductions will } \\
\text { primarily be obtained through } \\
\text { efforts to reduce building and } \\
\text { transportation energy. } \\
\text { AMWTP contract completion will } \\
\text { contribute to further reductions } \\
\text { toward the goal. }\end{array}$ & Medium \\
\hline
\end{tabular}


Table ES-2. (continued).

\begin{tabular}{|c|c|c|c|c|}
\hline $\begin{array}{l}\text { SSPP } \\
\text { Goal }\end{array}$ & DOE Goal & Performance Status & $\begin{array}{c}\text { Planned Actions and } \\
\text { Contribution }\end{array}$ & $\begin{array}{c}\text { Risk of } \\
\text { Non- } \\
\text { Attainment }\end{array}$ \\
\hline 1.2 & $\begin{array}{l}13 \% \text { Scope } 3 \\
\text { GHG Reduction } \\
\text { by FY } 2020 \text { from } \\
\text { a FY } 2008 \\
\text { baseline. }\end{array}$ & $\begin{array}{l}\text { The INL Site combined } \\
\text { Scope } 3 \text { GHG emissions } \\
\text { are down } 7.3 \% \text { from the } \\
\text { FY } 2008 \text { baseline. }\end{array}$ & $\begin{array}{l}\text { The INL Site will reduce Scope } 3 \\
\text { GHG emissions primarily through } \\
\text { employee commute reduction } \\
\text { tactics and employee travel } \\
\text { reduction tactics. }\end{array}$ & Low \\
\hline 2.1 & $\begin{array}{l}30 \% \text { energy } \\
\text { intensity } \\
\text { reduction by } \\
\text { FY } 2015 \text { from a } \\
\text { FY } 2003 \\
\text { baseline }\end{array}$ & $\begin{array}{l}\text { The INL Site has reduced } \\
\text { energy intensity } 13.8 \% \\
\text { from the FY } 2003 \text { baseline } \\
\text { intensity as demonstrated } \\
\text { through data entered into } \\
\text { the CEDR and compared to } \\
\text { FY } 2003 \text { data. }\end{array}$ & $\begin{array}{l}\text { The INL Site short-range energy } \\
\text { reduction strategies account for a } \\
22 \% \text { reduction in energy intensity } \\
\text { by FY } 2015 \text {. An } 8 \% \text { gap in } \\
\text { electrical intensity reduction exists. } \\
\text { To achieve the initial } 22 \% \\
\text { reduction, capital project upgrades } \\
\text { are planned primarily through } \\
\text { alternative funding mechanisms that } \\
\text { include ESPC and UESC. Closing } \\
\text { this } 8 \% \text { energy reduction gap will } \\
\text { require approximately } \$ 42 \mathrm{M}-\$ 52 \mathrm{M} \\
\text { in energy efficiency projects. } \\
\text { Finally, AMWTP contract } \\
\text { completion will contribute to further } \\
\text { reductions, helping make progress } \\
\text { toward the goal. }\end{array}$ & Medium \\
\hline 2.2 & $\begin{array}{l}\text { Individual } \\
\text { buildings } \\
\text { metering for } \\
90 \% \text { of } \\
\text { electricity (by } \\
\text { October } 1 \text {, } \\
2012 \text { ); for } 90 \% \\
\text { of steam, natural } \\
\text { gas, and chilled } \\
\text { water (by } \\
\text { October } 1 \text {, } \\
2015 \text { ). }\end{array}$ & $\begin{array}{l}\text { The INL Site meters } 100 \% \\
\text { of its natural gas and } 49 \% \\
\text { of its electric usage. An } \\
\text { analysis was performed on } \\
\text { all existing infrastructure } \\
\text { that will still be in place in } \\
\text { FY } 2020 \text {. From this } \\
\text { analysis, the INL FY } 2011 \\
\text { Metering Plan (PLN-3911) } \\
\text { was developed to provide a } \\
\text { roadmap on how the INL } \\
\text { Site will reach the goal of } \\
\text { metering } 90 \% \text { of } \\
\text { electricity. } \\
\text { Metering was installed in } \\
\text { FY } 2012 \text { on three facilities } \\
\text { with the highest probability } \\
\text { of meeting the Guiding } \\
\text { Principles. }\end{array}$ & $\begin{array}{l}\text { Meters will be installed over the } \\
\text { next } 2 \text { years to be compliant with } \\
\text { the } 90 \% \text { metering goal for Nuclear } \\
\text { Energy (NE) facilities. The six } \\
\text { remaining facilities identified as } \\
\text { having the highest probability of } \\
\text { meeting the Guiding Principles are } \\
\text { targeted for meter installations in } \\
\text { FY } 2013 \text {. } \\
\text { All other meters are planned for } \\
\text { installation through ESPC projects. } \\
\text { DOE Environmental Management } \\
\text { (EM) may install meters on up to } 12 \\
\text { INTEC buildings between FY } 2013 \\
\text { and FY } 2015 \text { as funding is made } \\
\text { available. }\end{array}$ & $\begin{array}{l}\text { Low } \\
\text { The INL Site } \\
\text { did not meet } \\
\text { the } \\
\text { October } 01 \text {, } \\
2012 \text { deadline, } \\
\text { but will meet } \\
\text { the } 90 \% \text { goal } \\
\text { for NE } \\
\text { buildings } \\
\text { within } 2 \text { years. }\end{array}$ \\
\hline
\end{tabular}


Table ES-2. (continued).

\begin{tabular}{|c|c|c|c|c|}
\hline $\begin{array}{l}\text { SSPP } \\
\text { Goal }\end{array}$ & DOE Goal & Performance Status & $\begin{array}{c}\text { Planned Actions and } \\
\text { Contribution }\end{array}$ & $\begin{array}{c}\text { Risk of } \\
\text { Non- } \\
\text { Attainment }\end{array}$ \\
\hline 2.3 & $\begin{array}{l}\text { Cool roofs, } \\
\text { unless } \\
\text { uneconomical, } \\
\text { for roof } \\
\text { replacements } \\
\text { unless project } \\
\text { already has } \\
\text { CD-2 approval. } \\
\text { New roofs must } \\
\text { have thermal } \\
\text { resistance of at } \\
\text { least R-30. }\end{array}$ & $\begin{array}{l}\text { The INL Site replaced } \\
21,869 \mathrm{ft}^{2} \text { of roofing on } \\
\text { four existing buildings } \\
\text { with cool roofs using the } \\
\text { Roof Asset Management } \\
\text { Program (RAMP). Cool } \\
\text { roofs were also installed on } \\
\text { three new INL facilities. A } \\
\text { total of } 379,000 \mathrm{ft}^{2} \text { or } 17 \% \\
\text { of DOE-NE owned and } \\
\text { operating INL roof area } \\
\text { now have cool roofs. }\end{array}$ & $\begin{array}{l}\text { INL roof replacements planned for } \\
\text { FY } 2013 \text { with the RAMP program } \\
\text { will result in new cool roofs } \\
\text { exceeding } 12,000 \mathrm{ft}^{2} \text {. } \\
\text { Additionally, the new Research and } \\
\text { Education Laboratory (REL) will be } \\
\text { complete in FY } 2013 \text { and will } \\
\text { include a cool roof on } \\
\text { approximately } 44,000 \mathrm{ft}^{2} \text {. } \\
\text { AMWTP project completion does } \\
\text { not involve installation of cool } \\
\text { roofs. } \\
\text { ICP contract extension includes } \\
\text { narrative for possible cool roof } \\
\text { evaluation at CPP- } 666 \text {, dependent } \\
\text { upon funding priority }\end{array}$ & Low \\
\hline 2.4 & $\begin{array}{l}15 \% \text { of existing } \\
\text { buildings greater } \\
\text { than } 5,000 \text { gross } \\
\text { square feet } \\
\text { (GSF) are } \\
\text { compliant with } \\
\text { the Guiding } \\
\text { Principles of } \\
\text { High } \\
\text { Performance } \\
\text { Sustainable } \\
\text { Buildings } \\
\text { (HPSB) by } \\
\text { FY 2015 }\end{array}$ & $\begin{array}{l}\text { The INL Site has } 2 \% \text { of } \\
\text { existing facilities that are } \\
\text { compliant with the Guiding } \\
\text { Principles. } \\
\text { Although the INL Site } \\
\text { requires only } 26 \text { facilities } \\
\text { to achieve the Guiding } \\
\text { Principles ( } 15 \% \text { of the } \\
\text { entire INL Site), INL } \\
\text { identified } 27 \text { facilities with } \\
\text { the highest probability of } \\
\text { meeting the Guiding } \\
\text { Principles. These facilities } \\
\text { were entered into Portfolio } \\
\text { Manager, are planned for } \\
\text { meter installations, and are } \\
\text { included in plans for } \\
\text { energy and efficiency } \\
\text { upgrades. } \\
\text { Of these } 27 \text { facilities, two } \\
\text { are currently Leadership in } \\
\text { Energy and Environmental } \\
\text { Design (LEED } \\
\text { certified, four are in } \\
\text { construction and are } \\
\text { awaiting LEED } \\
\text { certification, and the } \\
\text { balance are being worked } \\
\text { for Guiding Principle } \\
\text { implementation. }\end{array}$ & $\begin{array}{l}\text { All enduring infrastructure at } \\
\text { Central Facilities Area and the } \\
\text { Advanced Test Reactor Complex } \\
\text { (ATR), and low security facilities at } \\
\text { the Specific Manufacturing } \\
\text { Complex (SMC) were evaluated as } \\
\text { part of developing INL ESPC } \\
\text { Project } 3 \text {. The five Guiding } \\
\text { Principles are planned for } \\
\text { implementation through the ESPC, } \\
\text { although not at EM facilities. } \\
\text { In FY } 2013 \text {,assuming that funding } \\
\text { is available, INL will implement } \\
\text { projects in Idaho Falls (IF) Facilities } \\
\text { including IF-616 (WCB), IF-654 } \\
\text { (EROB), and IF-663 (Records } \\
\text { Storage Facility) that will help these } \\
\text { buildings obtain a passing Energy } \\
\text { Star rating score and will be further } \\
\text { evaluated using Portfolio Manager. } \\
\text { INL is planning to certify IF-663 } \\
\text { and IF-654 in FY } 2013 \text { as meeting } \\
\text { the Guiding Principles using } \\
\text { Portfolio Manager, an increase of } \\
1 \% \text {. } \\
\text { Non- Attainment Issue: } \\
\text { Full implementation of the Guiding } \\
\text { Principles is highly dependent upon } \\
\text { energy and water usages and } \\
\text { securing an acceptable Energy Star }\end{array}$ & $\begin{array}{l}\text { Medium } \\
\text { See Non- } \\
\text { Attainment } \\
\text { Issue statement }\end{array}$ \\
\hline
\end{tabular}


Table ES-2. (continued).

\begin{tabular}{|c|c|c|c|c|}
\hline $\begin{array}{l}\text { SSPP } \\
\text { Goal }\end{array}$ & DOE Goal & Performance Status & $\begin{array}{l}\text { Planned Actions and } \\
\text { Contribution }\end{array}$ & $\begin{array}{c}\text { Risk of } \\
\text { Non- } \\
\text { Attainment }\end{array}$ \\
\hline & & & $\begin{array}{l}\text { score. As the final buildings are } \\
\text { metered, there may not be sufficient } \\
\text { time to implement changes to } \\
\text { improve the Energy Star score. The } \\
\text { INL Site is responsible for obtaining } \\
\text { Guiding Principle certification on } \\
15 \% \text { of the INL Site Buildings ( } 26 \\
\text { total based on current enduring } \\
\text { infrastructure numbers). AMWTP } \\
\text { and ICP projects focus on } \\
\text { completing the cleanup mission so } \\
\text { most facilities have a limited } \\
\text { operational term and only minimal } \\
\text { planned investments. Upgrades to } \\
\text { meet the guiding principles will be } \\
\text { considered for maintenance projects } \\
\text { or if major facility modifications are } \\
\text { required to meet mission } \\
\text { requirements. AMWTP and ICP } \\
\text { facilities were removed from the } \\
\text { ESPC Project } 3 \text { scope at EM HQ } \\
\text { direction in FY } 2011 \text { due to } \\
\text { uncertain operating terms and are } \\
\text { not expected to contribute to this } \\
\text { goal. INL had planned to obtain } \\
\text { Guiding Princple certification on } \\
16 \text { buildings, which equates to } 15 \% \\
\text { of the INL/NE controlled buildings. } \\
\text { Although a new plan is in place to } \\
\text { achieve Guiding Principle } \\
\text { compliance on all } 26 \text {, the remaining } \\
10 \text { facilities were added in FY } 2012 \\
\text { to INL's total and may not reach } \\
\text { Guiding Principle implementation } \\
\text { until after FY } 2015 \text {. Energy } \\
\text { efficiency project funding, meter } \\
\text { installation, and operating } \\
\text { considerations may cause the new } \\
\text { planned Guiding Principle } \\
\text { implementation date to slip } 1 \text { or } 2 \\
\text { years for the additional } 10 \\
\text { buildings. }\end{array}$ & \\
\hline 2.5 & $\begin{array}{l}\text { All new } \\
\text { construction, } \\
\text { major } \\
\text { renovations, and } \\
\text { alternations of } \\
\text { buildings greater } \\
\text { than } 5,000 \mathrm{GSF} \\
\text { must comply }\end{array}$ & $\begin{array}{l}\text { The INL Site ensures all } \\
\text { new construction, major } \\
\text { renovations, and } \\
\text { alternations of buildings } \\
\text { greater than } 5,000 \mathrm{GSF} \\
\text { comply with the Guiding } \\
\text { Principles and where the } \\
\text { work exceeds } \$ 5 \mathrm{M} \text {, are }\end{array}$ & $\begin{array}{l}\text { INL's new Radiological } \\
\text { Environmental Sciences Laboratory } \\
\text { (IF-683) and Energy Systems } \\
\text { Laboratory (IF-685) will be } \\
\text { certified at LEED }{ }^{\mathrm{TM}} \text { Gold in FY } \\
2013 \text { and the new Research and } \\
\text { Education Laboratory (IF-688) is } \\
\text { under construction and is expected }\end{array}$ & Low \\
\hline
\end{tabular}


Table ES-2. (continued).

\begin{tabular}{|c|c|c|c|c|}
\hline $\begin{array}{l}\text { SSPP } \\
\text { Goal }\end{array}$ & DOE Goal & Performance Status & $\begin{array}{c}\text { Planned Actions and } \\
\text { Contribution }\end{array}$ & $\begin{array}{c}\text { Risk of } \\
\text { Non- } \\
\text { Attainment }\end{array}$ \\
\hline & $\begin{array}{l}\text { with the Guiding } \\
\text { Principles }\end{array}$ & $\begin{array}{l}\text { LEED }^{\text {TM }} \text { Gold certified or } \\
\text { equivalent. }\end{array}$ & $\begin{array}{l}\text { to be submitted for LEED } \\
\text { FY } 2014 \text {. The INL TYSP } \\
\text { institutionalizes sustainability as a } \\
\text { core driver during campus and } \\
\text { building planning. } \\
\text { AMWTP and ICP project } \\
\text { completion requires minimal } \\
\text { construction and do not certify } \\
\text { temporary structures used for waste } \\
\text { exhumation. }\end{array}$ & \\
\hline 2.6 & $\begin{array}{l}7.5 \% \text { of annual } \\
\text { electricity } \\
\text { consumption } \\
\text { from renewable } \\
\text { sources by } \\
\text { FY } 2013 \text { and } \\
\text { thereafter ( } 5 \% \\
\text { FY 2010-FY } \\
\text { 2012). }\end{array}$ & $\begin{array}{l}\text { The INL Site produced no } \\
\text { onsite renewable energy, } \\
\text { and the electricity available } \\
\text { for purchase is currently } \\
\text { obtained from up to } 60 \% \\
\text { renewable (including old } \\
\text { hydro electric). The INL } \\
\text { Site is meeting the goal by } \\
\text { procuring } 22,000 \mathrm{MWh} \text { of } \\
\text { Renewable Energy } \\
\text { Certificates (RECs) from } \\
\text { the local Utility, Idaho } \\
\text { Falls Power. This purchase } \\
\text { represents } 10 \% \text { of the INL } \\
\text { Site electric usage. This } \\
\text { REC purchase supports } \\
\text { further renewable energy } \\
\text { development and is a } \\
\text { premium purchase of new } \\
\text { renewable power from the } \\
\text { local supplier utility. }\end{array}$ & $\begin{array}{l}\text { INL continues to evaluate } \\
\text { Renewable Energy Generation } \\
\text { capability as technology changes } \\
\text { and will annually purchases RECs } \\
\text { in amounts as outlined in the } \\
\text { Energy Policy Act of } 2005 \text {. } \\
\text { AMWTP and ICP project } \\
\text { completion do not involve } \\
\text { installation of renewable energy } \\
\text { systems. } \\
\text { Non-Attainment Issue: } \\
\text { Although technically feasible, low } \\
\text { electric costs and long paybacks } \\
\text { make renewable energy installation } \\
\text { on the INL Site economically } \\
\text { infeasible. ESPC Project } 3 \text { review } \\
\text { of renewable energy installation } \\
\text { (solar, and wind) resulted in } 211 \\
\text { and } 60 \text { year return on investments } \\
\text { for } 50 \text { kilowatt and } 1 \text { megawatt } \\
\text { projects respectively. These } \\
\text { projects may have provided up to a } \\
\text { maximum of } 2 \% \text { onsite renewable } \\
\text { energy generation. An INL } \\
\text { estimate for a privately operated } \\
\text { wind farm installed on INL property } \\
\text { would require } \$ 15 \mathrm{M} \text { in supporting } \\
\text { infrastructure for the project to be } \\
\text { commercially viable. Onsite solar } \\
\text { installation would require over } \\
\$ 35 \mathrm{M} \text {, plus the cost of maintaining } \\
\text { an owned solar generating facility. }\end{array}$ & $\begin{array}{l}\text { Medium } \\
\text { See Non- } \\
\text { Attainment } \\
\text { Issue statement }\end{array}$ \\
\hline
\end{tabular}


Table ES-2. (continued).

\begin{tabular}{|c|c|c|c|c|}
\hline $\begin{array}{l}\text { SSPP } \\
\text { Goal }\end{array}$ & DOE Goal & Performance Status & $\begin{array}{c}\text { Planned Actions and } \\
\text { Contribution }\end{array}$ & $\begin{array}{c}\text { Risk of } \\
\text { Non- } \\
\text { Attainment }\end{array}$ \\
\hline 3.1 & $\begin{array}{l}10 \% \text { annual } \\
\text { increase in fleet } \\
\text { alternative fuel } \\
\text { consumption by } \\
\text { FY } 2015 \text { relative } \\
\text { to a FY } 2005 \\
\text { baseline. }\end{array}$ & $\begin{array}{l}\text { The INL Site has exceeded } \\
\text { the FY } 2015 \text { goal by } \\
\text { increasing alternative fuel } \\
154 \% \text { relative to FY } 2005 \text {. } \\
\text { In FY } 2012 \text {, the INL Site } \\
\text { used } 194,429 \text { gasoline } \\
\text { gallon equivalents of } \\
\text { alternative fuels. }\end{array}$ & $\begin{array}{l}\text { The INL Site will continue to obtain } \\
\text { alternative fuel vehicles in support } \\
\text { of this goal. INL will optimize the } \\
\text { fleet through bus and heavy truck } \\
\text { replacements that are more efficient } \\
\text { and operate on biodiesel. } \\
\text { However, recent DOE-HQ and } \\
\text { Government Services } \\
\text { Administration (GSA) direction has } \\
\text { placed an emphasis on hybrid } \\
\text { vehicle purchases. Hybrid vehicles } \\
\text { are not flex fuel capable, so future } \\
\text { alternative fuel consumption may } \\
\text { decrease. }\end{array}$ & Low \\
\hline 3.2 & $\begin{array}{l}2 \% \text { annual } \\
\text { reduction in fleet } \\
\text { petroleum } \\
\text { consumption by } \\
\text { FY } 2012 \text { relative } \\
\text { to a FY } 2005 \\
\text { baseline. }\end{array}$ & $\begin{array}{l}\text { In FY } 2012 \text {, the INL Site } \\
\text { used } 747,777 \text { gasoline } \\
\text { gallon equivalents of } \\
\text { petroleum, a } 20.3 \% \\
\text { reduction from FY } 2005 \text {. }\end{array}$ & $\begin{array}{l}\text { The INL Site will continue to obtain } \\
\text { increasingly fuel-efficient light-duty } \\
\text { vehicles, continue to use B } 20 \text { and } \\
\text { E- } 85 \text { fuels, and research the } \\
\text { feasibility of implementing } \\
\text { alternative fuel for bus operations. } \\
\text { EM mission completion will } \\
\text { contribute to further reductions, } \\
\text { helping exceed the goal. }\end{array}$ & Low \\
\hline 3.3 & $\begin{array}{l}75 \% \text { of light- } \\
\text { duty vehicle } \\
\text { purchases must } \\
\text { consist of } \\
\text { alternative fuel } \\
\text { vehicles (AFVs) } \\
\text { by FY } 2020 \text { and } \\
\text { thereafter. }\end{array}$ & $\begin{array}{l}\text { The INL Site acquired nine } \\
\text { light-duty vehicles in } \\
\text { FY } 2012 \text {, all of which are } \\
\text { flex-fuel }(100 \%)\end{array}$ & $\begin{array}{l}\text { The INL Site will continue to } \\
\text { replace the current fleet with AFVs } \\
\text { as GSA allows. } \\
\text { However, hybrid vehicles are not } \\
\text { AFVs and DOE-HQ is mandating } \\
\text { hybrid vehicles be purchased. This } \\
\text { may greatly affect the percentage of } \\
\text { vehicles acquired and the amount of } \\
\text { alternative fuel used at INL. }\end{array}$ & $\begin{array}{l}\text { Low } \\
\text { Based on } \\
\text { directives and } \\
\text { vehicles } \\
\text { available from } \\
\text { GSA. }\end{array}$ \\
\hline 3.4 & $\begin{array}{l}\text { Reduce fleet } \\
\text { inventory by } \\
35 \% \text { by FY } 2013 \\
\text { relative to a } \\
\text { FY } 2005 \\
\text { baseline. }\end{array}$ & $\begin{array}{l}\text { The INL Site has met the } \\
35 \% \text { reduction mandate } 1 \\
\text { year early. } \\
\text { AMWTP removed vehicles } \\
\text { from the fleet by } \\
\text { participating in the INL } \\
\text { transportation program. }\end{array}$ & $\begin{array}{l}\text { INL will further support this goal by } \\
\text { eliminating } 100 \text { light-duty vehicles } \\
\text { during FY } 2013 \text {. } \\
\text { EM progress toward mission } \\
\text { completion at the AMWTP and } \\
\text { INTEC facilities mission and } \\
\text { progress will remove dozens of } \\
\text { vehicles from the fleet inventory in } \\
\text { the next five years. } \\
\text { ICP forecasts a reduction in the } \\
\text { heavy equipment rental fleet from } \\
\text { FY } 2012 \text { levels. }\end{array}$ & Low \\
\hline
\end{tabular}


Table ES-2. (continued).

\begin{tabular}{|c|c|c|c|c|}
\hline $\begin{array}{l}\text { SSPP } \\
\text { Goal }\end{array}$ & DOE Goal & Performance Status & $\begin{array}{c}\text { Planned Actions and } \\
\text { Contribution }\end{array}$ & $\begin{array}{c}\text { Risk of } \\
\text { Non- } \\
\text { Attainment }\end{array}$ \\
\hline 4.1 & $\begin{array}{l}26 \% \text { water } \\
\text { intensity } \\
\text { reduction by FY } \\
2020 \text { from a FY } \\
2007 \text { baseline. }\end{array}$ & $\begin{array}{l}\text { The INL Site has reduced } \\
\text { water use intensity by } \\
11.4 \% \text { and total water } \\
\text { pumped by } 18.3 \% \text { as } \\
\text { compared to the FY } 2007 \\
\text { baseline. }\end{array}$ & $\begin{array}{l}\text { The INL Site will continue to } \\
\text { develop and install projects that } \\
\text { conserve water, through ESPC } \\
\text { project development at the ATR } \\
\text { Complex and Central Facilities } \\
\text { Area (CFA) and additional } \\
\text { internally funded projects. } \\
\text { EM mission progress, including } \\
\text { completion of the AMWTP will } \\
\text { contribute to further reductions in } \\
\text { both water use and the building } \\
\text { footprint. } \\
\text { Non-Attainment Issue: } \\
\text { Low-cost water and electricity } \\
\text { result in long paybacks on water } \\
\text { efficiency projects that make } \\
\text { implementation economically } \\
\text { infeasible. Due to significant } \\
\text { fluctuations in water demand } \\
\text { (reactor operations and } \\
\text { environmental factors such as } \\
\text { weather and wild land fires), the } \\
\text { INL Site is unlikely to maintain the } \\
\text { FY } 2012 \text { reductions and achieve this } \\
\text { goal. Retrofits on existing industrial } \\
\text { process, primarily at the ATR } \\
\text { Complex, are estimated to cost } \\
\text { between } \$ 100 K \text { to nearly } \$ 75 \mathrm{M} \text {. } \\
\text { The INL Site estimates a water } \\
\text { intensity reduction of } 10 \%-12 \% \text { by } \\
\text { FY } 2020 \text {. }\end{array}$ & $\begin{array}{l}\text { Medium } \\
\text { See Non- } \\
\text { Attainment } \\
\text { Issue statement }\end{array}$ \\
\hline 4.2 & $\begin{array}{l}20 \% \text { water } \\
\text { consumption } \\
\text { reduction of } \\
\text { industrial, } \\
\text { landscaping, and } \\
\text { agricultural } \\
\text { (ILA) water by } \\
\text { FY } 2020 \text { from a } \\
\text { FY } 2010 \\
\text { baseline. }\end{array}$ & $\begin{array}{l}\text { ILA water is not applicable } \\
\text { to the INL Site. All water } \\
\text { obtained by the INL Site is } \\
\text { obtained from the Snake } \\
\text { River Plain Aquifer and is } \\
\text { potable. The INL Site does } \\
\text { not have access to any non- } \\
\text { potable water supplies. }\end{array}$ & NA. & Low \\
\hline
\end{tabular}


Table ES-2. (continued).

\begin{tabular}{|c|c|c|c|c|}
\hline $\begin{array}{l}\text { SSPP } \\
\text { Goal }\end{array}$ & DOE Goal & Performance Status & $\begin{array}{c}\text { Planned Actions and } \\
\text { Contribution }\end{array}$ & $\begin{array}{l}\text { Risk of } \\
\text { Non- } \\
\text { Attainment }\end{array}$ \\
\hline 5.1 & $\begin{array}{l}\text { Divert at least } \\
50 \% \text { of non- } \\
\text { hazardous solid } \\
\text { waste, excluding } \\
\text { construction and } \\
\text { demolition } \\
\text { debris, by FY } \\
2015 \text {. }\end{array}$ & $\begin{array}{l}\text { The INL Site diverted } 33 \% \\
\text { of its non-hazardous solid } \\
\text { waste in FY } 2012 \text {. }\end{array}$ & $\begin{array}{l}\text { The INL Site will continue to } \\
\text { evaluate potential outlets and the } \\
\text { expansion of recyclable waste } \\
\text { streams and to increase further the } \\
\text { amount of wastes diverted from the } \\
\text { landfill. Contracts for mowing will } \\
\text { be evaluated and modified to } \\
\text { incorporate recycle or mulching. }\end{array}$ & Medium \\
\hline 5.2 & $\begin{array}{l}\text { Divert at least } \\
50 \% \text { of } \\
\text { construction and } \\
\text { demolition } \\
\text { (C\&D) materials } \\
\text { and debris by FY } \\
2015 \text {. }\end{array}$ & $\begin{array}{l}\text { The INL Site diverted } 30 \% \\
\text { of its C\&D materials in } \\
\text { FY } 2012 \text {. }\end{array}$ & $\begin{array}{l}\text { The INL Site will work to } \\
\text { incorporate additional materials into } \\
\text { current C\&D waste diversion } \\
\text { process. However, limited market } \\
\text { availability and significant funds } \\
\text { needed to implement a C\&D recycle } \\
\text { program fully will ultimately drive } \\
\text { the decision. }\end{array}$ & Medium \\
\hline 6.1 & $\begin{array}{l}\text { Procurements } \\
\text { meet } \\
\text { sustainability } \\
\text { requirements and } \\
\text { include } \\
\text { sustainable } \\
\text { acquisition } \\
\text { clause ( } 95 \% \\
\text { each year). }\end{array}$ & $\begin{array}{l}\text { INL implemented a new } \\
\text { automated tracking process } \\
\text { in FY } 2012 \text { and } \\
\text { preliminary numbers show } \\
\text { that } 100 \% \text { of the } \\
\text { construction and janitorial } \\
\text { contracts contained the } \\
\text { sustainable acquisition } \\
\text { clause in the fourth quarter. } \\
\text { For the entire Fiscal Year, } \\
71 \% \text { of the construction } \\
\text { and janitorial contracts } \\
\text { contained the sustainable } \\
\text { acquisition clauses. }\end{array}$ & $\begin{array}{l}\text { The INL Site is incorporating } \\
\text { numerous changes to improve the } \\
\text { Sustainable Acquisition Program } \\
\text { including procedures, policies, and } \\
\text { enhanced work processes that } \\
\text { increase the visibility, availability, } \\
\text { and use of sustainable products. } \\
\text { Sustainable acquisition contract } \\
\text { clauses, including reporting } \\
\text { requirements, were incorporated } \\
\text { into EM contracts in FY } 2012 \text {. }\end{array}$ & Low \\
\hline 7.1 & $\begin{array}{l}\text { All data centers } \\
\text { are metered to } \\
\text { measure a } \\
\text { monthly Power } \\
\text { Utilization } \\
\text { Effectiveness } \\
\text { (PUE) }(100 \% \text { by } \\
\text { FY 2015). }\end{array}$ & $\begin{array}{l}\text { INL meters two Data } \\
\text { Centers and is connected to } \\
\text { the building control } \\
\text { system. } \\
\text { ICP does not yet meter } \\
\text { either data center. }\end{array}$ & $\begin{array}{l}\text { The data center definition was } \\
\text { expanded in FY 2012, so ICP now } \\
\text { has two data centers listed in the } \\
\text { CEDR. Funding dependent, meters } \\
\text { will be installed in the future. }\end{array}$ & Low \\
\hline
\end{tabular}


Table ES-2. (continued).

\begin{tabular}{|c|c|c|c|c|}
\hline $\begin{array}{l}\text { SSPP } \\
\text { Goal }\end{array}$ & DOE Goal & Performance Status & $\begin{array}{c}\text { Planned Actions and } \\
\text { Contribution }\end{array}$ & $\begin{array}{c}\text { Risk of } \\
\text { Non- } \\
\text { Attainment }\end{array}$ \\
\hline 7.2 & $\begin{array}{l}\text { Maximum } \\
\text { annual weighted } \\
\text { average PUE of } \\
1.4 \text { by FY } 2015 \text {. }\end{array}$ & $\begin{array}{l}\text { The INL High } \\
\text { Performance Computing } \\
\text { (HPC) data center PUE is } \\
\text { 1.34. The Information } \\
\text { Operations Research } \\
\text { Center (IORC) data center } \\
\text { PUE is } 2.03 \text {. }\end{array}$ & & Low \\
\hline 7.3 & $\begin{array}{l}\text { Electronic } \\
\text { Stewardship - } \\
100 \% \text { of eligible } \\
\text { PCs, laptops, and } \\
\text { monitors with } \\
\text { power } \\
\text { management } \\
\text { activity } \\
\text { implemented and } \\
\text { in use by FY } \\
2012 \text {. }\end{array}$ & $\begin{array}{l}\text { INL won the Federal } \\
\text { Electronics Challenge } \\
\text { (FEC) Silver award in FY } \\
2012 \text {. Power management } \\
\text { controls are in place on the } \\
\text { majority of eligible } \\
\text { computer systems. At INL, } \\
100 \% \text { of eligible PCs have } \\
\text { power management } \\
\text { controls. AMWTP has } \\
\text { installed power } \\
\text { management controls on } \\
\text { eligible computers. }\end{array}$ & $\begin{array}{l}\text { The INL Site will continue to } \\
\text { demonstrate commitment to } \\
\text { electronic stewardship through } \\
\text { compliant procurements and policy } \\
\text { changes. } \\
\text { INL will continue to support the } \\
\text { FEC and work towards achieving } \\
\text { the Gold Award. }\end{array}$ & Low \\
\hline
\end{tabular}




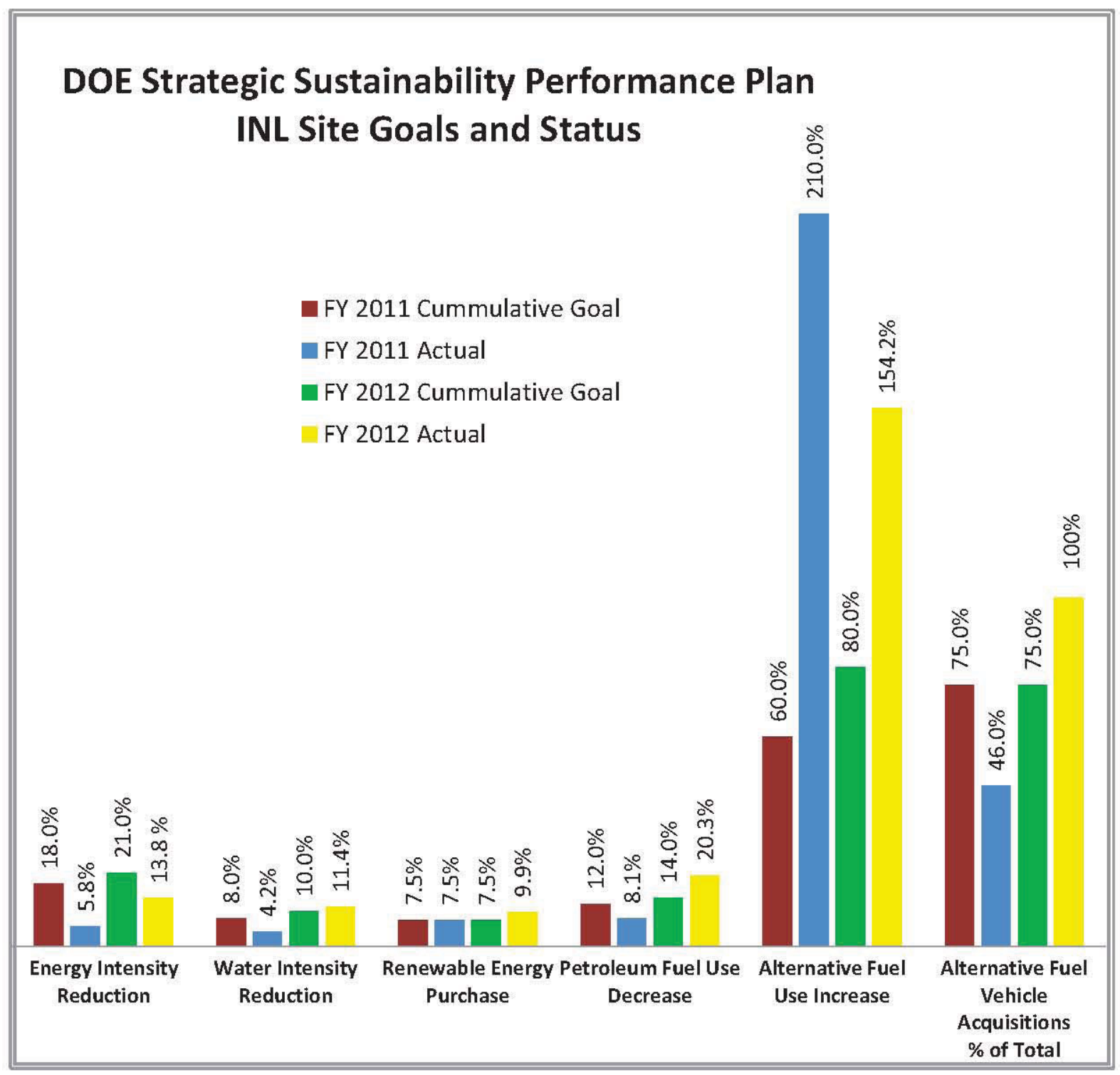

Figure ES-1. Current INL Site status to the DOE goals.

Figure ES-1 shows the INL Site cumulative goal and status for FY 2011 and FY 2012. The cumulative goals are based on individual baseline years as required in Executive Orders. 
(This Page Intentionally Left Blank)

xxiv 


\section{CONTENTS}

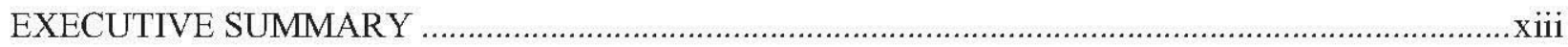

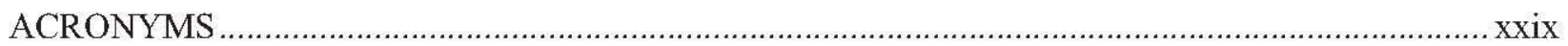

1. GOAL PERFORMANCE REVIEW AND PLANS ............................................................. 1

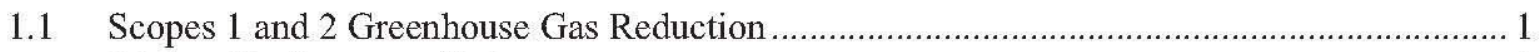

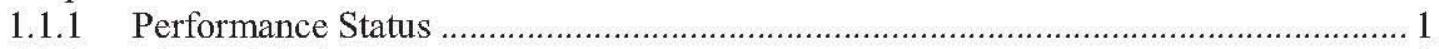

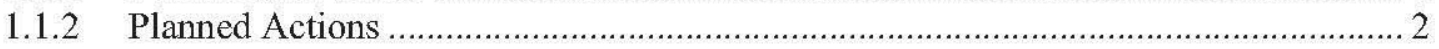

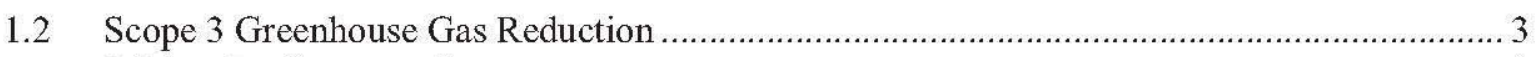

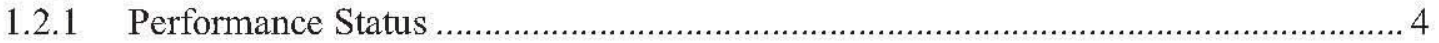

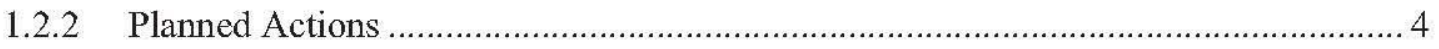

2. ENERGY MANAGEMENT AND HIGH PERFORMANCE SUSTAINABLE

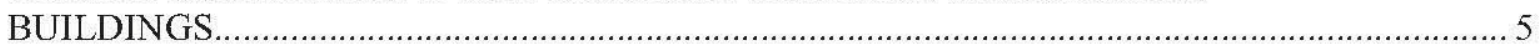

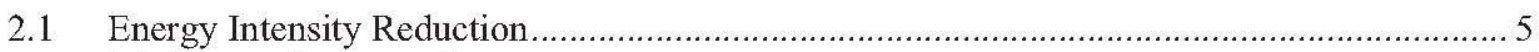

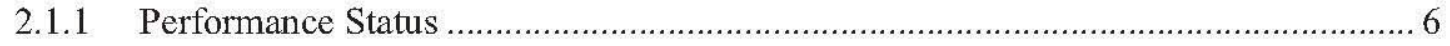

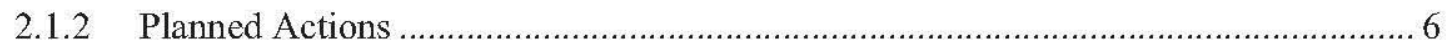

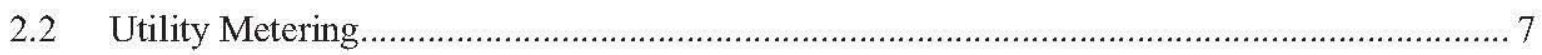

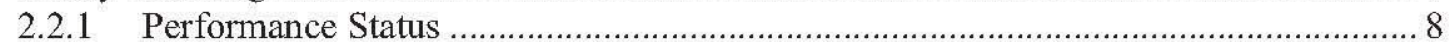

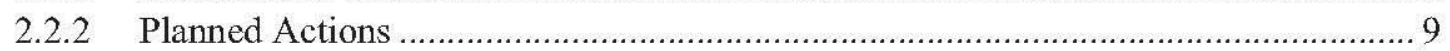

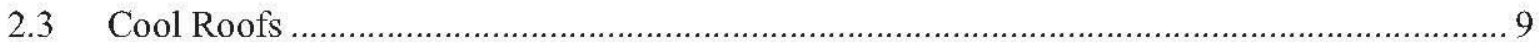

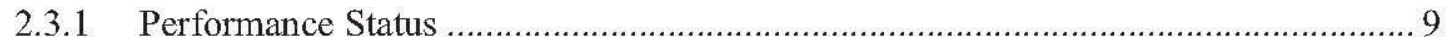

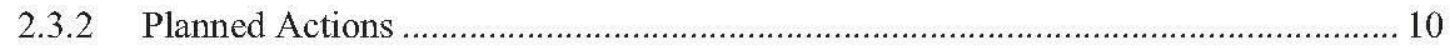

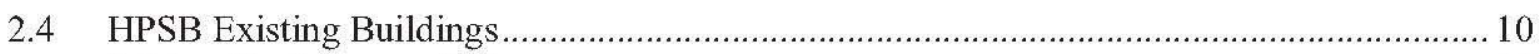

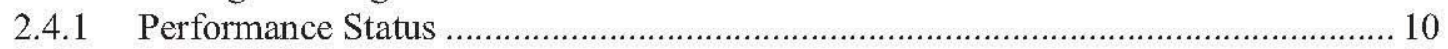

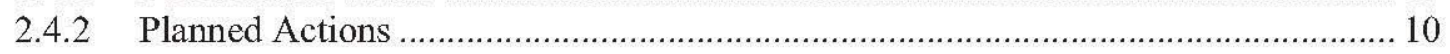

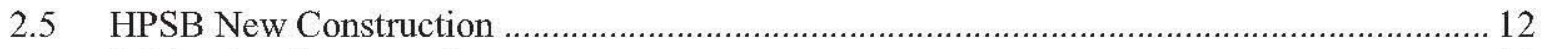

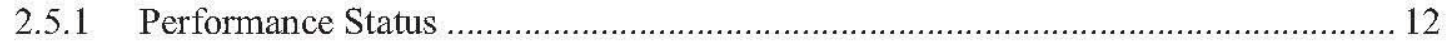

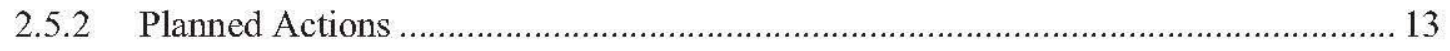

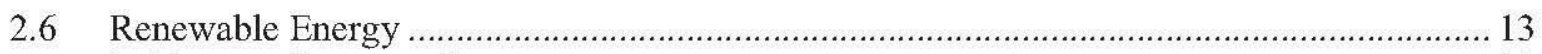

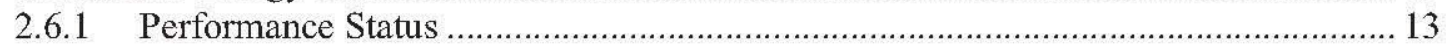

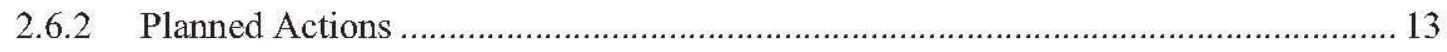

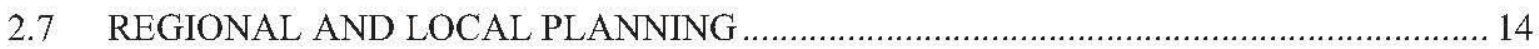

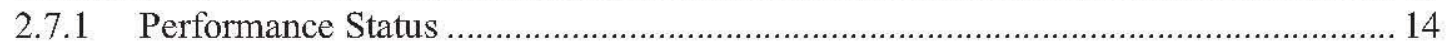

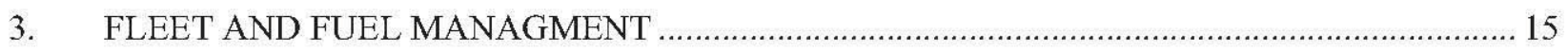

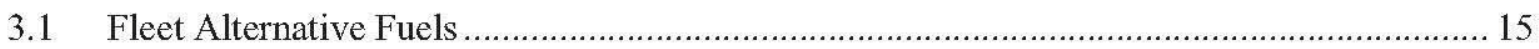

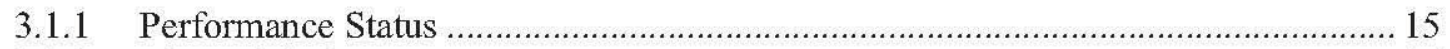

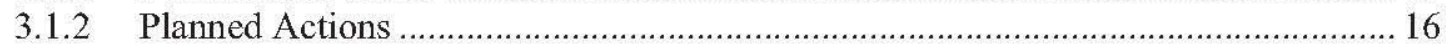

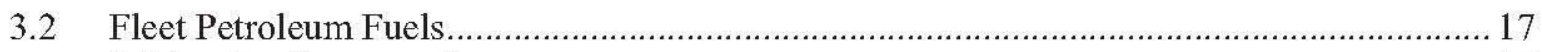

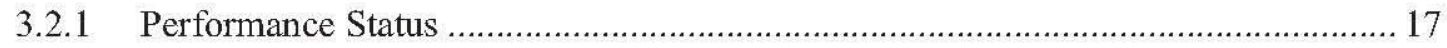

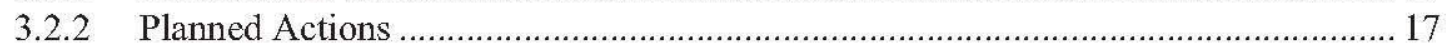

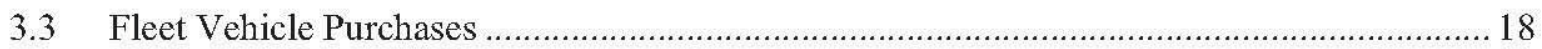

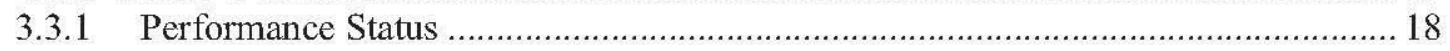

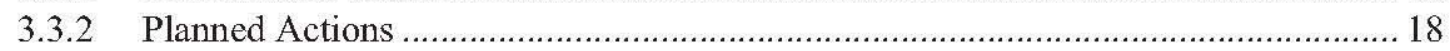

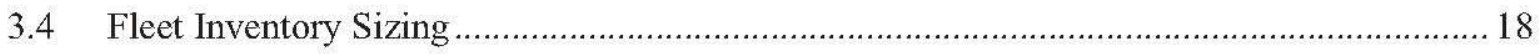

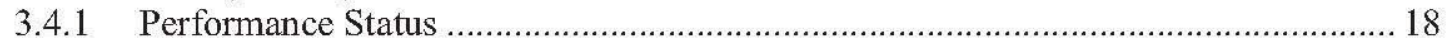




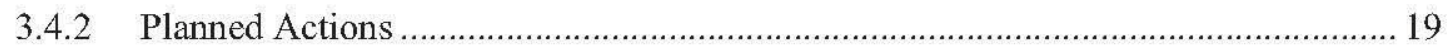

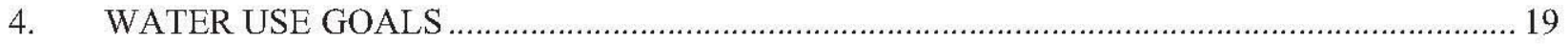

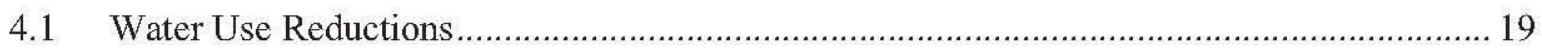

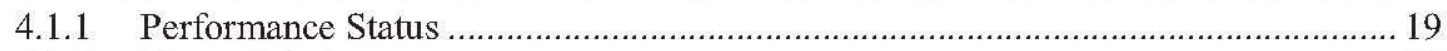

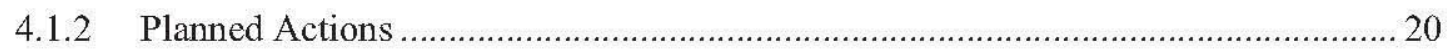

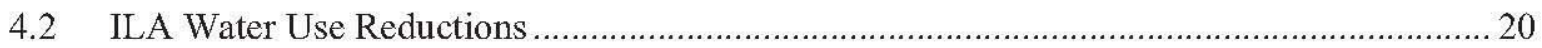

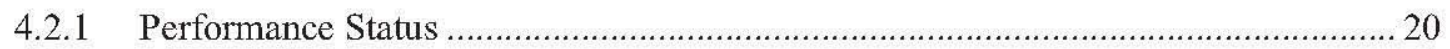

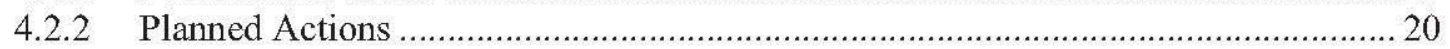

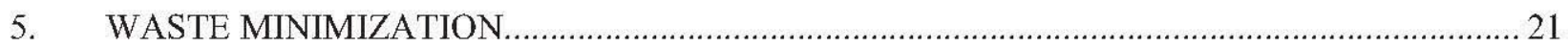

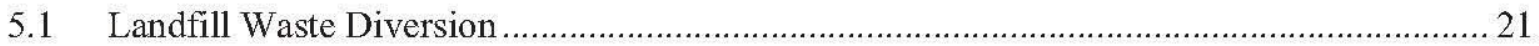

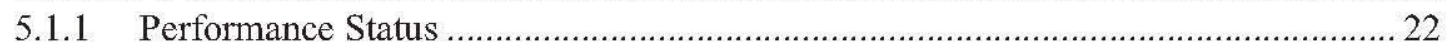

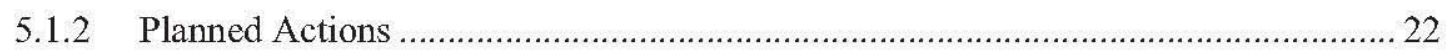

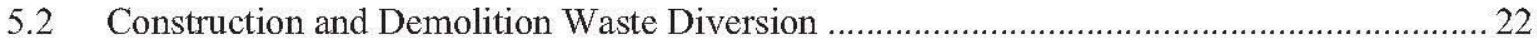

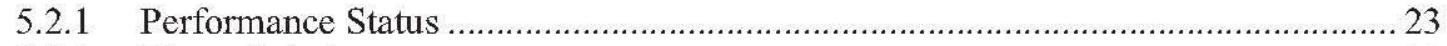

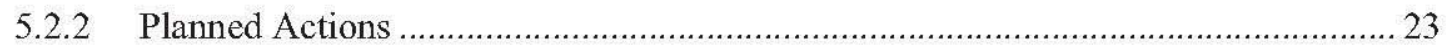

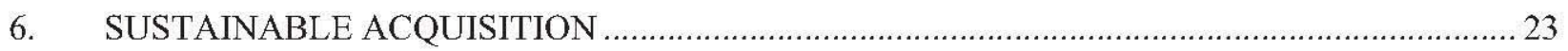

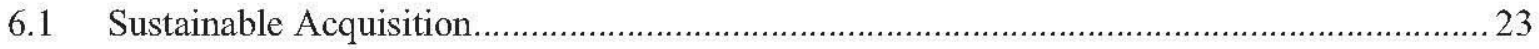

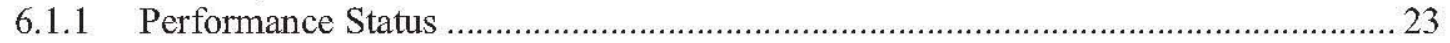

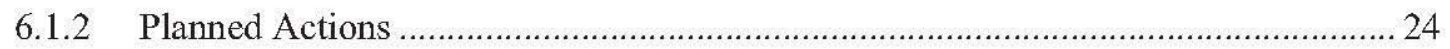

7. DATA CENTERS AND ELECTRONICS STEWARDSHIP ...................................................24

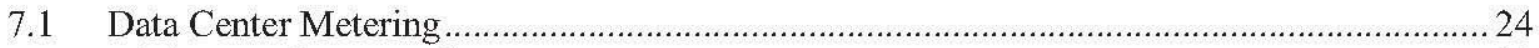

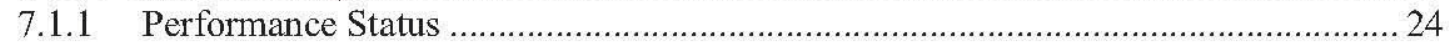

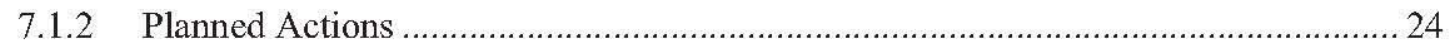

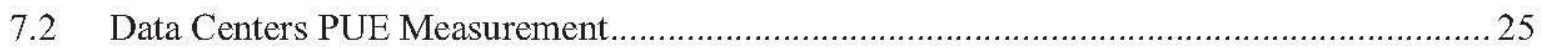

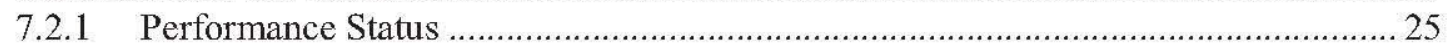

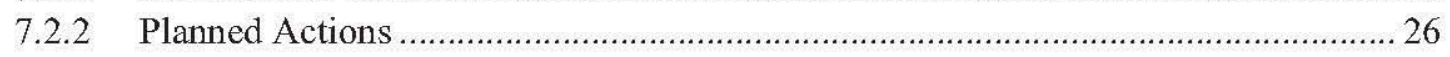

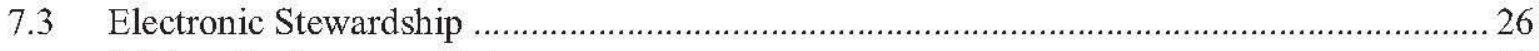

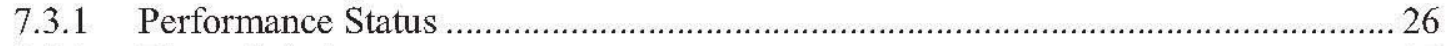

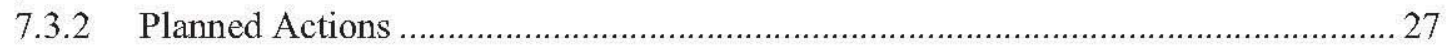

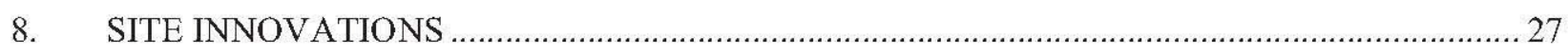

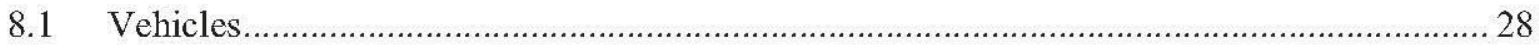

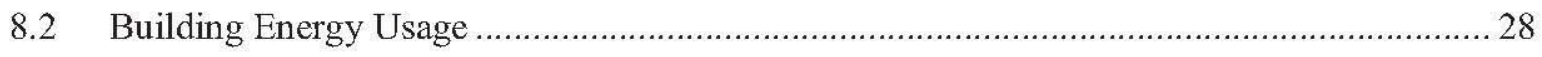

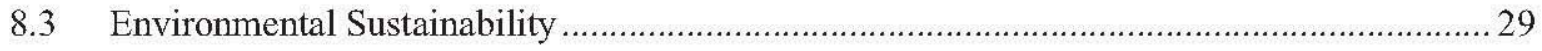

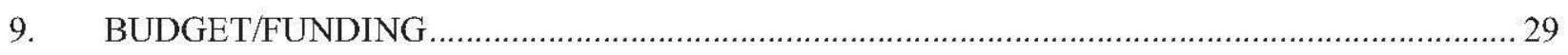

9.1 Energy Savings Performance Contracts (ESPC) Projects ................................................29

9.2 Sustainability related investments as required by Circular A-11 ................................... 29

9.3 Integration of Long-Term Sustainability Goals into the Budget Process ......................... 30

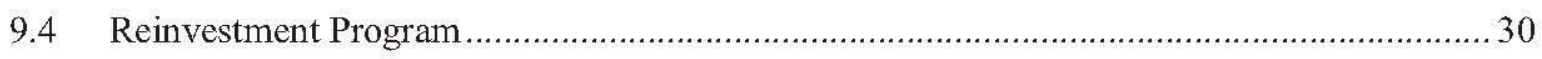

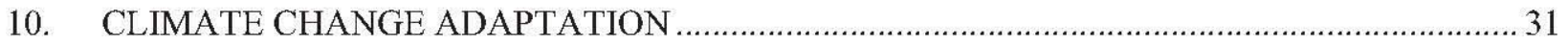

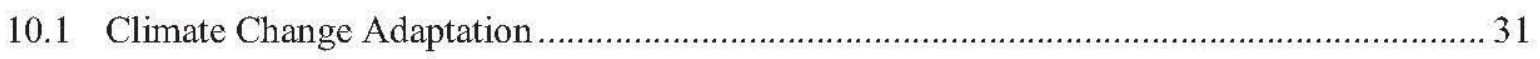

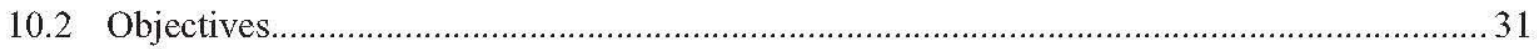


10.3 Current Understanding of Potential Climate Change Effects and Impacts ...................... 32

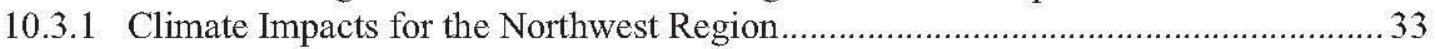

10.3.2 Climate Impacts for the Southwest Region Applicable to INL ............................. 34

10.3.3 Climate Impacts for the Great Plains Region Applicable to INL ........................ 34

10.4 Actions to Fulfill DOE Climate Adaptation Objectives.................................................... 35

10.4.1 Goal 1: Improving our Understanding of Climate Impacts in INL's Region ............35

10.4.2 Goal 2: Assessing Climate Change Vulnerability and Risk at INL .......................... 36

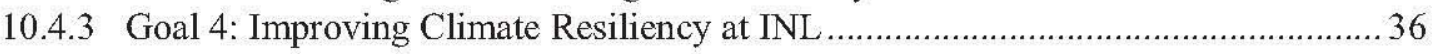

10.5 Synergies with Climate Mitigation Efforts and Laboratory Mission ..............................37

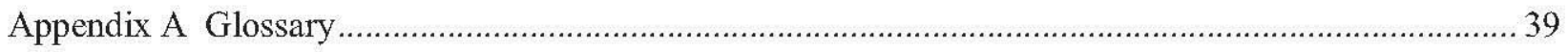

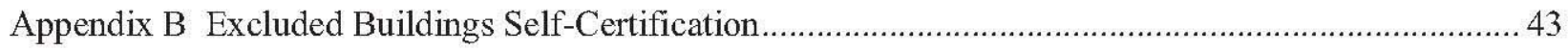

Appendix C Consolidated Energy Data Report (CEDR) ....................................................... 49

\section{FIGURES}

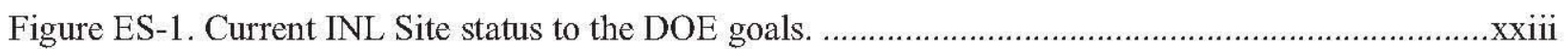

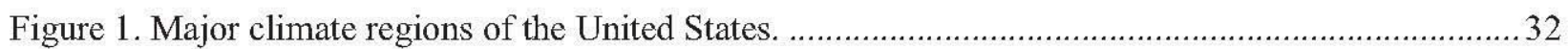

Figure 2. Major landscapes of the United States, as described by the U.S. Geologic Survey

(USGS)

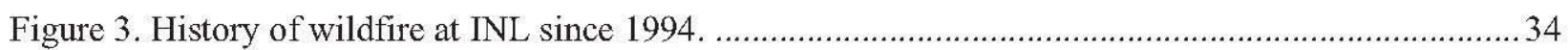

\section{TABLES}

Table ES-1. DOE Sustainability Performance Office (SPO) Key Milestones Status ...........................xiv

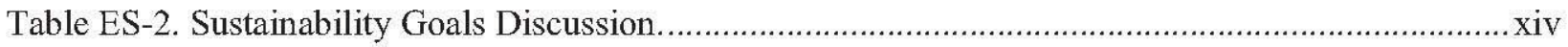

Table 1. INL Site Scopes 1 and 2 combined GHG calculation results for FY 2008 and FY 2012, and the FY 2020 goal.

Table 2. INL Site Scope 3 GHG calculation results for FY 2008 and FY12, and the FY 2020

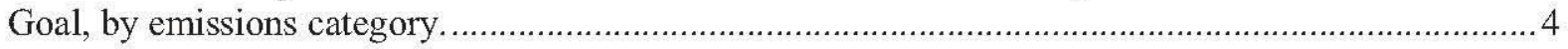

Table 3. Buildings planned to meet Guiding Principles. .............................................................. 11 
(This Page Intentionally Left Blank)

xxviii 


\section{ACRONYMS}

\begin{tabular}{|c|c|}
\hline AFV & Alternative Fuel Vehicle \\
\hline AMWTP & Advanced Mixed Waste Treatment Project \\
\hline ARRA & American Recovery and Reinvestment Act \\
\hline ATR & Advanced Test Reactor \\
\hline $\mathrm{B} 20$ & Biodiesel \\
\hline BEA & Battelle Energy Alliance, LLC \\
\hline Btu & British thermal unit \\
\hline C\&D & Construction and Demolition \\
\hline CAES & Center for Advanced Energy Studies \\
\hline CD-2 & Conceptual Design \\
\hline CDP & Calcine Disposition Project \\
\hline CEDR & Consolidated Energy Data Report \\
\hline CFA & Central Facilities Area \\
\hline $\mathrm{CNG}$ & Compressed Natural Gas \\
\hline CRAC & Computer Room Air Condition \\
\hline CUI & Controlled Unclassified Information \\
\hline $\mathrm{D} \& \mathrm{D}$ & Decontamination and Dismantlement \\
\hline DOE & Department of Energy \\
\hline DOE-ID & Department of Energy Idaho Operations Office \\
\hline $\mathrm{E}-85$ & Ethanol 85 \\
\hline EBR-I & Experimental Breeder Reactor 1 \\
\hline ECM & Energy Conservation Measure \\
\hline EM & Environmental Management \\
\hline EMS & Environmental Management System \\
\hline $\mathrm{EO}$ & Executive Order \\
\hline EPA & Environmental Protection Agency \\
\hline EPEAT & Electronic Product Environmental Assessment Tool \\
\hline EPSCoR & Experimental Program to Stimulate Competitive Research \\
\hline EROB & Engineering Research Office Building \\
\hline ES\&H & Environment, Safety, and Health \\
\hline ESCo & Energy Services Contractor \\
\hline ESL & Energy Systems Laboratory \\
\hline ESPC & Energy Savings Performance Contract \\
\hline
\end{tabular}


FAST Fleet Automotive Statistical Tool

FEC Federal Electronics Challenge

FEMP Federal Energy Management Program

FIMS Facilities Information Management System

FRAMES Fire Research and Management Exchange System

FY Fiscal Year

GHG Greenhouse Gas

GPS Global Positioning System

GSA General Services Administration

gsf Gross Square Feet

HEV hybrid electric vehicle

HPC High Performance Computing

HPSB high performance and sustainable building

HQ Headquarters

HVAC Heating, Ventilating, and Air Conditioning

HWMA Hazardous Waste Management Act

IAB INL Administration Building

ICP Idaho Cleanup Project

ILA industrial, landscaping, and agricultural

IM Information Management

INL Idaho National Laboratory

INTEC Idaho Nuclear Technology and Engineering Center

IORC Information Operations and Research Center

IRC INL Research Center

ISMS Integrated Safety Management Systems

IT Information Technology

IWTU Integrated Waste Treatment Unit

LEED $^{\mathrm{TM}} \quad$ Leadership in Energy and Environmental Design

LNG Liquefied Natural Gas

MFC Materials and Fuels Complex

MIT Massachusetts Institute of Technology

MT Metric Tons

MWWI Mountain West Water Institute

NE Nuclear Energy

NKN Northwest Knowledge Network 


$\begin{array}{ll}\text { NNSA } & \text { National Nuclear Security Administration } \\ \text { NRF } & \text { Naval Reactors Facility } \\ \text { NSF } & \text { National Science Foundation } \\ \text { PDU } & \text { Process Demonstration Unit } \\ \text { PHEV } & \text { Plug-in Hybrid Electric Vehicle } \\ \text { PPTRS } & \text { Pollution Prevention Tracking and Reporting System } \\ \text { PUE } & \text { Power Utilization Effectiveness } \\ \text { R\&D } & \text { Research and Development } \\ \text { RAMP } & \text { Roof Asset Management Program } \\ \text { RCRA } & \text { Resource Conservation and Recovery Act } \\ \text { REC } & \text { Renewable Energy Certificate } \\ \text { REL } & \text { Research and Education Laboratory } \\ \text { RESL } & \text { Radiological Environmental Sciences Laboratory } \\ \text { RFID } & \text { Radio Frequency Identification } \\ \text { ROB } & \text { Research Office Building } \\ \text { SDOP } & \text { Six Drum Overpack } \\ \text { SIF } & \text { Strategic Investment Funding } \\ \text { SMC } & \text { Specific Manufacturing Capability } \\ \text { SPO } & \text { Sustainability Performance Office } \\ \text { SSPP } & \text { Strategic Sustainability Performance Plan } \\ \text { TSA-RE } & \text { Transuranic Storage Area - Retrieval Enclosure } \\ \text { TSB } & \text { Technical Support Building } \\ \text { TTAF } & \text { Test Train Assembly Facility } \\ \text { TYSP } & \text { Ten-Year Site Plan } \\ \text { UESC } & \text { Utility Energy Services Contract } \\ \text { UPS } & \text { Uninterruptable Power Supply } \\ \text { USGBC } & \text { United States Green Building Council } \\ \text { UTV } & \text { Utility Terrain Vehicle } \\ \text { VM } & \text { Virtual Machine } \\ \text { WCB } & \text { Willow Creek Building } \\ & \end{array}$


(This Page Intentionally Left Blank) 


\section{FY 2013 INL Site Sustainability Plan with the FY 2012 Annual Report \\ 1. GOAL PERFORMANCE REVIEW AND PLANS}

For the purposes of this document, the "INL Site" is considered all operating contractors and the Department of Energy Idaho Operations Office (DOE-ID), and includes the industrial complexes located west of Idaho Falls and the Idaho Falls buildings. Idaho National Laboratory (INL) is considered to be those facilities operated by Battelle Energy Alliance, LLC (BEA). The Advanced Mixed Waste Treatment Project (AMWTP) and Idaho Cleanup Project (ICP) are referred to by their noted acronyms and include all facilities under their individual responsibility.

The DOE Environmental Management (EM) mission assumptions for this Plan include the cessation of AMWTP operations and AMWTP facilities achieving a cold, dark, and dry status by FY 2018.

\subsection{Scopes 1 and 2 Greenhouse Gas Reduction}

\section{$28 \%$ Scope 1 \& 2 GHG reduction by $F Y 2020$ from a FY 2008 baseline.}

Executive Order (EO) 13514 mandates that agencies develop specific greenhouse gas (GHG) reduction targets. Department of Energy (DOE) has set a reduction target of $28 \%$ for Scope 1 and 2 GHGs. The EO sets FY 2008 as the baseline year against which reductions will be measured.

The INL Site reported Scope 1 and Scope 2 GHG emissions for the baseline year, FY 2008, and annually thereafter. Scope 1 and Scope 2 are defined as:

- Scope 1. Direct or INL Site-owned emissions that are produced onsite, such as stationary combustion (from fuel combustion), mobile combustion (from fleet vehicles), and fugitive emissions (from refrigerants, onsite landfills, and onsite wastewater treatment). These include emissions that may benefit another entity or contractor, but for which the INL Site controls or owns the associated process.

- Scope 2. Indirect or shared emissions produced by INL Site's electricity, heat, and steam purchases. (Note that INL Site did not purchase heat or steam during FY 2009 through FY 2012.)

The INL Site contractors' Environmental Management Systems (EMS) provide the framework and process for evaluating and monitoring Scopes 1,2, and $3 \mathrm{GHG}$ emissions and related reduction activities. On an annual basis, appropriate sustainability targets are developed and monitored through the EMS to support the overall reduction in GHG emissions.

The challenge is to minimize the impact of operations while increasing the growth of the INL Site, balanced with EM closure activities. INL is integrating environmental performance improvement in the areas that matter most to its stakeholders and the Laboratory, including minimizing the environmental footprint, taking a progressive approach to climate change, and championing energy conservation.

\subsubsection{Performance Status}

Based on data entered into the Consolidated Energy Data Report (CEDR) and as shown in Table 1, the INL Site has reduced Scopes 1 and 2 combined emissions by $20.3 \%$ in FY 2012 as compared to the FY 2008 baseline. 
Table 1. INL Site Scopes 1 and 2 combined GHG calculation results for FY 2008 and FY 2012, and the FY 2020 goal.

\begin{tabular}{|c|c|c|c|}
\hline $\begin{array}{c}\text { Emission } \\
\text { Type }\end{array}$ & $\begin{array}{c}\text { FY } 2008 \\
\text { Baseline } \\
\text { (MT COㄹ } \\
\end{array}$ & $\begin{array}{l}\text { FY } 2012 \text { Actual } \\
\left.\text { (MT CO } \mathrm{CO}_{2} \mathrm{e}\right)\end{array}$ & $\begin{array}{c}\text { FY } 2020 \\
\text { Reduction Goal } \\
\left(\mathrm{MT} \mathrm{CO} \mathrm{CO}_{2} \mathrm{e}\right)\end{array}$ \\
\hline $\begin{array}{l}\text { Scopes } 1 \text { \& } 2 \\
\text { Combined }\end{array}$ & $141,102.9$ & $112,484.3$ & $101,594.1$ \\
\hline
\end{tabular}

Many factors influence the INL Site's GHG emissions, including the large land area on which the Laboratory's facilities are located. The area requires long commutes and an extensive fleet to provide transportation for desert site workers, and contains many antiquated inefficient facilities built before the current appreciation for energy efficiency and high-performance design. These factors tie directly into the following conclusions from the INL Site's baseline GHG inventory:

- Electricity is the largest contributor to the INL Site's GHG inventory

- Other sources with high emissions were stationary combustion and fugitive emissions from the onsite landfill

- Among the sources with low emissions within Scopes 1 and 2 were fugitive emissions from refrigerants and onsite wastewater treatment.

\subsubsection{Planned Actions}

The INL Site will continue to implement projects that reduce electricity and fuel usage, reducing corresponding Scope 1 and Scope 2 emission reductions. ICP will continue its closure mission, discontinuing processes and making facilities inactive and cold, dark, and dry; or demolishing what is no longer needed. Knowing the target emission for each as found in the INL GHG Reduction Strategy helps prioritize and plan projects accordingly.

Mobile Combustion Reduction tactics include:

- Take advantage of mass transportation and shuttles

Significant petroleum reduction and associated GHG reduction could be realized by moving additional numbers of the AMWTP contract force away from the current vanpool system to the existing INL bus operation. A majority of the AMWTP work force could be absorbed into the current bus operations schedule (i.e., fill the empty seats on buses currently traveling to/from the Site).

- Add one additional Park and Ride location to further reduce employee commute and bus fleet fuel usage.

- Evaluate technology that will allow INL to operate the bus fleet on "mixed" fuel, which is a combination of compressed natural gas (CNG) and biodiesel. This may allow INL to reduce fuel usage by up to $30 \%$.

- Eliminate trips by using tools such as video and Web conferencing for meetings.

The use of "Go to Meeting" and other similar Web conferencing tools are available and use is expanding at INL.

- Use alternative modes of transportation such as bicycles and low-speed vehicles as appropriate.

Low-speed vehicles are available and in use inside Site areas. 
- Right Size Fleet.

INL will allocate the majority of equipment to the end user except for a small centralized fleet of approximately 100 pieces of equipment. In doing so, the custodian will be accountable for cost, acquisition, maintenance, and storage of the equipment. Fleet Management will maintain input on all equipment acquisitions. INL looks to increase the vehicle pool total with one new J-hook truck and two new beds during FY 2013 to enable the use of multiple bed types on one truck.

The Naval Reactors Facility (NRF) has chosen not to implement the park-n-ride concept; however, fuel used to transport NRF staff contributes to INL Site emissions, as INL is the owner and operator of the transportation system. INL will continue to optimize NRF bus routes and run times.

Fugitive emission reduction tactics include:

- Work with recycling coordinator to identify waste diversion opportunities, including increasing the types and quantities of items sent for recycling and implementing composting. These activities will assist with meeting the EO 13514 waste diversion goals.

- Investigate installing a gas collection system at the onsite landfill to use as an energy source.

- Electricity emission reduction tactics include continuing evaluation of onsite renewable energy projects for cost effective options as technology and energy prices change, although there are no plans or funding to install in the near term.

- Use the following tactics to reduce direct purchased electricity:

- Satisfy sustainable acquisition requirements to purchase Energy Star and Federal Energy Management Program (FEMP) devices (EO 13514 requirement)

- Meet green building goals for new and existing buildings (Guiding Principles and Leadership in Energy and Environmental Design $\left[\mathrm{LEED}^{\mathrm{TM}}\right]$ Gold certification)

- Continue educational campaign to change employee behaviors (turn off lights and computers when leaving at end of shift, utilize power management when available, avoid using space heaters, personal fridges, etc.)

- Upgrade Idaho Falls facilities using either Utility Energy Services Contract (UESC) funds or internal upgrade program.

\subsection{Scope 3 Greenhouse Gas Reduction}

\section{$13 \%$ Scope 3 GHG reduction by $F Y 2020$ from a FY 2008 baseline.}

Executive Order 13514 mandates that agencies develop specific GHG reductions. DOE has set a reduction target of $13 \%$ for Scope 3 greenhouse gases. The EO sets 2008 as the baseline year against which reductions will be measured.

The INL Site reported Scope 3 GHG emissions for the baseline year, FY 2008, and annually thereafter. Using the Global Reporting Initiative standards, Scope 3 is defined as:

- Indirect or shared emissions generated by outsourced activities that benefit the INL Site (occur outside the INL Site's organizational boundaries, but are a consequence of the INL Site's activities).

This can include a large number of activities, so the INL Site focused on transmission and distribution losses, employee commuting, employee travel, contracted waste disposal and contracted wastewater treatment since these categories were identified in the Technical Support Document for required reporting. Other activities that could be included in Scope 3 include the embodied emissions of purchased materials.

The INL Site contractors' EMS provides the framework and process for evaluating and monitoring Scopes 1, 2, and 3 GHG emissions and related reduction activities. On an annual basis, appropriate sustainability targets are developed and monitored through the EMS to support the overall reduction in GHG emissions. 
As the EM missions end at various site locations, overall Scope 3 emissions are expected to decrease. Between FY 2011 and FY 2017, employees traveling to and from the Site location may be reduced by as many as 2,000 when subcontractors are included. Removing vehicles directly impacts Scope 1 and Scope 3 emissions.

The challenge is to minimize the impact of operations while increasing the growth of the INL Site. INL is integrating environmental performance improvement in the areas that matter most to its stakeholders and the Laboratory, including minimizing the environmental footprint, taking a progressive approach to climate change, and championing energy conservation.

\subsubsection{Performance Status}

Based on data entered into the CEDR and as shown in Table 2, the INL Site has reduced Scope 3 emissions by $7.3 \%$ in FY 2012 as compared to the FY 2008 baseline.

Table 2. INL Site Scope 3 GHG calculation results for FY 2008 and FY12, and the FY 2020 Goal, by emissions category.

\begin{tabular}{|c|c|c|c|}
\hline $\begin{array}{c}\text { Emission } \\
\text { Type }\end{array}$ & $\begin{array}{l}\text { FY } 2008 \text { Baseline } \\
\left(\mathrm{MT} \mathrm{CO}_{2} \mathrm{e}\right)\end{array}$ & $\begin{array}{l}\text { FY } 2012 \text { Actual } \\
\left(\mathrm{MT} \mathrm{CO}_{2} \mathrm{e}\right)\end{array}$ & $\begin{array}{c}\text { FY } 2020 \\
\text { Reduction Goal } \\
\left(\mathrm{MT} \mathrm{CO}_{2} \mathrm{e}\right)\end{array}$ \\
\hline Scope 3 & $28,853.7$ & $26,760.9$ & $25,102.7$ \\
\hline
\end{tabular}

Similar to Scopes 1 and 2 GHG emissions described above, one of the most significant factors that influence INL's Scope 3 GHG emissions is the large land area that requires long commutes (approximately 50 miles, one way). Transportation fuel was, in turn, the largest source of GHG emissions within Scope 3. Another source with high emissions was business air travel. Sources with low emissions were contracted waste disposal, contracted wastewater treatment, and business ground travel (rental and personal vehicles).

INL continues to reduce GHGs by transporting employees with a modernized transportation system, taking nearly 2,000 cars per day off the road. By streamlining the INL mass transit system that provides safe, efficient, and sustainable transportation to work for INL employees throughout the eastern Idaho region, INL encourages travel behavior changes to reduce carbon emissions and fossil fuel consumption, increased highway safety, and in doing so, INL models future trends in mass transit to local governments planning across the region. Other actions include instituting a park and ride system, relocating employees to town offices, use of ethanol 85 (E-85) and biodiesel (B20) fuels, and use of modern buses, vans, and light-duty vehicles to reduce carbon emissions.

\subsubsection{Planned Actions}

The INL Site will continue to implement projects that reduce employee commute, employee travel, waste disposal, and minimize electric usage to reduce Transmission and Distribution losses. Corresponding Scope 3 emission reductions will occur. Knowing the target emission for each GHG category as found in the INL GHG Reduction Strategy, helps prioritize and plan projects accordingly.

Employee Commute Reduction tactics include:

- Change commute by increasing carpools, change personal car use to INL buses

- Parking management through parking pricing (e.g., begin charging, give discount for rideshare parking); preferential parking (e.g., designated carpool and vanpool spaces); parking supply reduction.

- Move employee work locations from Site to town when reasonable.

- Increase INL Bus ridership for Site employees by $5 \%$. 
- Increase telecommuting.

- Telework centers.

- Facility enhancements.

- Secure bike storage or bike racks, shower facilities, and lockers.

- Use alternative fueled vehicles on business travel.

- Promote use of emission-free transportation source such as walking and biking.

- Subsidies:

- Vanpool subsidies on a limited or continual basis.

- Empty seat subsidy - to limit the amount start-up riders have to pay until new riders join.

- Bike maintenance subsidy.

Employee Travel Reduction strategies:

- Use video and web conferencing to hold virtual meetings and avoid travel when possible.

- Increase rentals of hybrid and alternative-fueled vehicles over traditional options on business travel.

- Reduce air travel, particularly short-range (<300 miles) air travel, except where necessary for mission accomplishment.

- Reduce car rentals by promoting carpooling at conferences and other meetings on business travel.

- Research establishing a government rate for plug-in hybrid electric vehicle (PHEV) and hybrid electric vehicle (HEV) rentals while on business travel.

- Encourage the use of public or group transportation modes at destination cities.

- Implement the Federal Commuter Tax Credit for employees who chose to car pool to work. Continue to encourage the use of teleconferencing and trip consolidation to reduce miles traveled.

\section{ENERGY MANAGEMENT AND HIGH PERFORMANCE SUSTAINABLE BUILDINGS}

\subsection{Energy Intensity Reduction}

\section{$30 \%$ energy intensity reduction by FY 2015 from a FY 2003 baseline.}

The INL Site goal for energy usage is a $30 \%$ reduction of energy intensity by FY 2015, as compared to the FY 2003 energy intensity baseline. Energy intensity is defined as energy use divided by building area and is measured in British Thermal Units per square foot $\left(\mathrm{Btu} / \mathrm{ft}^{2}\right)$. On average, an annual energy use reduction goal of $3 \%$ supports meeting the overall goal and provides a means to measure and trend progress. Energy intensive loads that are mission specific are excluded from the goal, according to the Guidelines Establishing Criteria for Excluded Buildings published by FEMP on January 27, 2006. The Advanced Test Reactor (ATR) and its support facilities are currently excluded from the reporting goal, but are not excluded from the responsibility to reduce energy use and GHGs where practicable.

Energy sources affected by this goal include electricity, natural gas, fuel oil, liquefied natural gas (LNG), and propane. Methods to reduce energy usage include capital project upgrades, operational modifications, and behavior changes by the INL workforce.

The INL Site energy intensity for FY 2012 was $157,690 \mathrm{Btu} / \mathrm{ft}^{2}$ as compared to $183,111 \mathrm{Btu} / \mathrm{ft}^{2}$ in FY 2003 for a calculated reduction of $13.8 \%$. This reduction falls short of the desired $21 \%$ cumulative reduction goal for FY 2012. 
Due to the nature of the various INL Site missions, many operations can be cyclical and result in varying usages of energy. As facilities are removed or processes are modified, the INL Site energy usage intensity can vary seemingly unrelated to actual overall reduction efforts.

The Integrated Waste Treatment Unit (IWTU) was completed in FY 2012 and houses the treatment process for treating the remaining wastes in the Tank Farm Facility. This treatment process initiated startup test operations in third quarter of FY 2012 and is anticipated to go online at the end of the third quarter FY 2013. The treatment process will use significant amounts of water and electricity. The facility does not currently have the capability for individual building metering and is captured in the overall Idaho Nuclear Technology Center (INTEC) metering. While an increase in INTEC energy use will occur, this process is expected to operate for less than 1 year to complete its mission, at which time the facility energy use should decrease back to the current INTEC load.

A future facility is currently being designed for the treatment of the calcine solids stored in the Calcine Solids Storage Facility located at INTEC. The Calcine Disposition Project (CDP) is planning to use a portion of the IWTU facility for this project. The CDP will also be an energy intensive treatment process that could be operational by FY 2020.

The INL Site is planning for significant growth to further its missions with additional process related facilities at the major desert site locations and additional office and laboratory facilities at Idaho Falls locations. The INL Ten-Year Site Plan (TYSP) (DOE/ID-11474) provides an overview and details of conceptual laboratory growth. Several of these new facilities are identified in the New Buildings worksheet of the CEDR.

\subsubsection{Performance Status}

To meet the Strategic Sustainability Performance Plan (SSPP) energy goal, the INL Site should be at a $21 \%$ reduction by the end of FY 2012 as compared to the established FY 2003 baseline. As demonstrated through data entered into the CEDR, the INL Site is at a $13.8 \%$ in energy reduction, which also represents a $12.8 \%$ reduction from FY 2011.

INL made progress in FY 2012 with realized savings from the Materials and Fuels Complex (MFC) Energy Savings Performance Contract (ESPC) project. Additional energy reductions were realized through completion of five projects with Strategic Sustainability Initiative funding. These projects cost $\$ 800 \mathrm{~K}$ and installed a new chiller and retrofitted lighting in IF-616/617 (Willow Creek Building [WCB]), new exterior lighting on IF-601 (Research Office Building [ROB]), new water fixtures in IF-602 (INL Research Center [IRC] Office Building), and new $\mathrm{CO}_{2}$ Controls in IF-654 (Engineering Research Office Building [EROB]).

\subsubsection{Planned Actions}

The INL Site capital project upgrades are funded primarily through alternative funding mechanisms that include ESPC and UESC. They both use external (non-DOE) funding for energy-related upgrades and are paid back over time using the energy cost savings generated by the project. The UESC process commenced on several owned and leased Idaho Falls facilities, but a major program requirement states that the payback must not exceed the length of the building lease. This greatly limits implementation as most leased facilities have 5 to 10 year leases and most payback calculations are 7 to 15 years. Still, the INL Site is actively pursuing these two alternative funding strategies to obtain additional energy savings. Finally, the INL Site will maximize the use of available utility incentive programs to help fund both internal and alternatively funded projects.

If funding becomes available during FY 2013, INL will supplement the ongoing ESPC project by providing Strategic Investment Funding (SIF) to implement projects that are either not readily adaptable to ESPC projects, or directly influence the efficiency of buildings that INL is pursuing the Guiding Principles. 
The following projects were identified that will contribute to continued energy reductions for the INL Site:

- Pending SIF funding allocation in FY 2013, installation of up to eight energy reduction projects are estimated for the Specific Manufacturing Capability (SMC), MFC, and the Idaho Falls facilities areas. These projects require an estimated \$1.2M and were developed during FY 2012 for implementation in FY 2013.

1. SMC Air Handler Heat Recovery Loop

2. INL Administration Building (IAB) Building Automation System and Lighting Controls

3. Information Operations and Research Center (IORC) Liebert System (9) Economizers

4. IF-603 Variable Frequency Drives and Controls

5. EROB Exterior Lighting

6. WCB Exterior Lighting

7. IRC Exterior Lighting

8. MFC Lighting Controls (500 Occupancy Sensors).

- ESPC development continues, including review and acceptance of the Final Proposal from AMERSCO and start of design and construction for all enduring facilities at Central Facilities Area (CFA), ATR-Complex, and selected facilities at the SMC facility. Energy Conservation Measures (ECM) being pursued include lighting, heating, ventilating, and air conditioning (HVAC) controls, boiler plant elimination and fuel conversions, a solar wall installation, and metering.

- ICP planned actions for energy reduction activities after FY 2012 consist of discontinuing processes as the cleanup mission is completed and continued Decontamination and Dismantlement (D\&D), which will result in a projected net reduction of building square footage for the INL EM program by the end of FY 2015 of $36,936 \mathrm{ft}^{2}$.

- AMWTP completion will place 12 facilities in a cold, dark, and dry status.

\subsection{Utility Metering}

Individual buildings or processes metering for 90\% of electricity (by October 1, 2012); for 90\% of steam, natural gas, and chilled water (by October 1, 2015).

Most of the INL Site buildings do not have meters installed. Limited meter installations have been performed primarily at MFC and CFA. Continued meter installations will be prioritized by the potential of the building to meet the Guiding Principles and the cost effectiveness of installing meters to meet the $90 \%$ metering goal.

In the latest Facilities Information Management System (FIMS) snapshot, the INL Site has over 900 real property assets such as facilities and structures, all of which potentially use electricity. The INL Site will continue to use DOE guidance and economic analysis to determine the most logical buildings to meter.

INL anticipates meeting the Guiding Principles on 27 facilities, which account for $15 \%$ of the enduring facilities at INL for both Nuclear Energy (NE) and EM programs. INL also anticipates meeting the goal to meter $90 \%$ of NE electric energy consumption by installing metering on an additional 15 facilities. In some cases, metering installations are common to both of these two separate metering related goals. 


\subsubsection{Performance Status}

\section{Metering for Guiding Principles}

INL anticipates meeting the Guiding Principles on 27 facilities, which account for $15 \%$ of the enduring buildings for both NE and EM. Twenty-one of these facilities are currently metered. Three of the 21 facilities had new meters installed during FY 2012: two at CFA and one new building at MFC.

\section{Metering for the $90 \%$ Goal}

Thirty-nine buildings in Idaho Falls and 41 buildings at the desert site are currently metered. These 80 buildings represent $49 \%$ of the total INL Site electric energy being metered. As funding is available, and priorities determined, there are an additional 70 buildings available for metering that would raise the total INL buildings metered to 150 .

All INL Idaho Falls town locations are currently metered for electricity and natural gas. In FY 2012, advanced metering was installed on 16 of the Idaho Falls town facilities through a project sponsored by Idaho Falls Power. In addition, the new Energy Systems Laboratory (ESL) was constructed in FY 2012 with plans to occupy early in FY 2013. The ESL facility contains significant metering and sub-metering intended to allow the facility manager precise control of building systems and to allow processes to be metered independently of the building energy use. With the new ESL facility, there will be 24 facilities counted in FY 2013 as having advanced metering and 16 facilities with standard meters for a total of 40 metered facilities.

Forty-one buildings at the desert site are currently metered, representing $39 \%$ of the desert site electricity metered. Twenty-six buildings are metered at MFC, five buildings are metered at CFA, one building is metered at the historic Experimental Breeder Reactor 1 (EBR-1) facility, and one building is metered at the ATR Complex. In addition, eight buildings at the ATR Complex are metered together as a process and are currently listed as INL's only Excluded Facilities for the energy efficiency goals. Thirtytwo of these facilities are metered with advanced meters, with the remaining nine metered with existing standard metering.

Using a combination of the DOE Metering Guidance (memorandum from Jennifer C. MacDonald, Director, Sustainability Performance Office, May 6, 2011), the guidance for Electric Metering in Federal Buildings (DOE/EE-0312), the DOE Buildings Electric Metering Guidance of September 27, 2006, and the FEMP Metering Best Practices (October 2007), the INL FY 2011 Metering Plan (PLN-3911) was prepared to identify the appropriate buildings for installing new utility metering. The INL Site will only install meters on facilities that have the greatest potential of achieving Guiding Principle compliance, are greater than $5,000 \mathrm{ft}^{2}$, are not cold, dark, and dry, and will be in use after FY 2020.

The INL Metering Plan spreadsheet tools were updated in FY 2012 to reflect final actual FY 2011 energy usage to determine the number of facilities needed to be metered to meet the $90 \%$ goal for just NE facilities and for all INL Site facilities. The spreadsheet tools indicated that an additional 15 buildings still require metering for $\mathrm{NE}$ to meet the $90 \%$ goal for $\mathrm{NE}$ electrical use. Of these 15 facilities, up to 12 may be metered by ESPC Project 3 and the final three meters should be installed at SMC facilities.

DOE-EM indicates that up to 12 facilities may be metered by EM if funding is available. These 12 moderately sized facilities are the only buildings that EM is currently planning to meter due to uncertainty of the operating life for most EM facilities. If these 12 buildings are metered, and if $\mathrm{NE}$ meters all of the $56 \mathrm{NE}$ buildings meeting the metering guidance, the spreadsheet tools calculate that only $71 \%$ of the total INL Site electric usage can be metered. The only way to exceed this $71 \%$ is to meter many smaller NE buildings and/or meter EM buildings with NE funding. 


\subsubsection{Planned Actions}

\section{Metering for the Guiding Principles}

The three facilities that had new meters installed during FY 2012 will be monitored and the data compiled for input into the Environmental Protection Agency (EPA) Portfolio Manager online tool to determine a score for energy use. This score will then be used to validate the buildings energy performance for the Guiding Principles.

To achieve Guiding Principle compliance, six remaining buildings of the 27 still need to have metering installed. Five of these remaining meters are planned for installation in FY 2013 by ESPC Project 3 and the final meter will be on the newly constructed Research and Education Laboratory (REL) that be occupied in early FY 2014.

\section{Metering for the $90 \%$ Goal}

Two new facilities will be added to the INL inventory. The ESL will be counted beginning in FY 2013 and the new REL will be completed and added in FY 2014. Both of these facilities are planned to be certified as LEED ${ }^{\mathrm{TM}}$ Gold and will have extensive metering including advanced metering by the City of Idaho Falls.

The Metering Plan spreadsheet tools indicate that an additional $15 \mathrm{NE}$ buildings require metering to meet the $90 \%$ Goal for NE. Installations are planned as follows:

- 12 facilities at CFA, MFC, and ATR Complex - Included in ESPC Project 3

- Three facilities at Test Area North (TAN) - Need to be installed through a work for others contract

- DOE-EM plans to install meters on up to 12 facilities if EM funding is available.

Total metering for the INL Site is summarized as follows:

- If only NE facilities are considered, 80 facilities are currently metered, two new Idaho Falls facilities will be added, and 15 additional meters must be installed to reach the $90 \%$ goal for a total of 97 meters.

- If the entire INL Site is considered, 80 facilities are currently metered, two new facilities will be added, 12 EM facilities will be metered, and 56 additional NE buildings are available to be metered for a total of 150 metered facilities to account for $71 \%$ of the INL Site's electric usage.

In addition to providing a means of trending and validating energy savings, metering also provides proactive space management opportunities. Building energy and water usage information assists with maintenance scheduling, enhanced resource utilization, and accurate space charge-back to building tenants. Advanced metering provides a method to encourage and validate employee behavior change, and provides a dependable tool for facility managers to tune building systems and controls.

\subsection{Cool Roofs}

Cool roofs, unless uneconomical, for roof replacements unless project already has CD-2 approval. New roofs must have thermal resistance of at least $R-30$.

\subsubsection{Performance Status}

In FY 2012, INL replaced 21,869 $\mathrm{ft}^{2}$ of roofing on MFC-768 Section J (MFC Power Plant), TRA-614 (Office Building/Bunkhouse/Dial Room), TRA-620 (Office Building), and TRA-670 Sections H through K (Advanced Test Reactor Building) with new roofing that meets the Secretary of Energy's requirements for "cool roofs" and eliminated over $\$ 260 \mathrm{k}$ of deferred maintenance. Additional "cool roofs" totaling $69,372 \mathrm{ft}^{2}$ were installed as part of the new construction for the new MFC Dial Room 
(MFC-1728), the Irradiated Materials Characterization Lab (IMCL, MFC-1729), the Energy Systems Lab (IF-685), and seismic upgrades to the MFC Analytical Lab.

A total of $379,000 \mathrm{ft}^{2}$ or $17 \%$ of DOE-NE owned and operating INL roof area now have cool roofs.

\subsubsection{Planned Actions}

INL will continue to use the DOE-National Nuclear Security Administration (NNSA) RAMP program to install an additional 7,200 $\mathrm{ft}^{2}$ of roofing in FY 2013 that meets the DOE "cool roof" requirement and will incorporate "cool roof" requirements into non-RAMP roof replacements as part of new construction and normal INL roof replacement and maintenance program.

In addition, INL will complete construction of the new REL at the Idaho Falls Campus in FY 2013. The total square footage of cool roof planned to be installed in 2013 is $51,000 \mathrm{ft}^{2}$.

The ICP contract extension identifies a currently unfunded project to evaluate Cool Roof technology when INTEC building roofs are replaced or significantly modified. In particular, CPP-666 was identified to apply Cool Roof technology when roofing maintenance is performed.

\subsection{HPSB Existing Buildings}

$15 \%$ of existing buildings greater than 5,000 gross square feet (gsf) to be compliant with the five Guiding Principles of High Performance Sustainable Buildings (HPSB) by FY 2015.

There are 27 Guiding Principles in five categories. To achieve compliance with the Guiding Principles, all 27 must be met.

As indicated in the FIMS database, the INL Site has 168 buildings that are appropriate to consider for audits and upgrades to implement the Guiding Principles. Fifteen percent of these buildings calculates to a minimum of 26 buildings that must meet the Guiding Principles by FY 2015. INL has selected 27 buildings with the highest probability of meeting the Guiding Principles. Of these 27 buildings, one is LEED $^{\mathrm{TM}}$ Certified, one is LEED ${ }^{\mathrm{TM}}$ Gold certified, and four are pending LEED ${ }^{\mathrm{TM}}$ Gold certification. The remaining 20 buildings will be targeted for the Guiding Principles compliance path.

\subsubsection{Performance Status}

The LEED ${ }^{\mathrm{TM}}$ Construction package for the new Radiological Environmental Sciences laboratory (IF683) was submitted during FY 2012.

Metering was installed on three facilities (two at CFA, and one at MFC) so that electrical data can be compiled for entry into Portfolio Manager. Energy and water reduction projects were completed in FY 2012 for IF-601, IF-602, IF-616, and IF-654 to further enhance the Energy Star grading for implementation of the Guiding Principles in these facilities.

INL documented compliance with 15 of the 27 Guiding Principles.

\subsubsection{Planned Actions}

INL Site facilities selected to meet the Guiding Principles do not include buildings owned by EM. Since the EM mission at the INL Site is to reduce footprint and complete the cleanup, the existing building life is either too short or too uncertain to invest in upgrades. This presents a challenge because the INL Site as a whole must meet the $15 \%$ goal ( 26 buildings) as noted above. INL identified 27 INL facilities ( 1 more than the required 26) that have the highest probability of fully implementing the Guiding Principles. However, this is 11 facilities above the original INL target of 16 facilities (15\% of the INL total) and is unlikely to occur by FY 2015 without additional project funding. All 27 facilities are listed in Table 3. This table includes information on metering and the year each building is expected to meet the Guiding Principles based on preliminary engineering evaluations. This table will be used as the work plan for prioritizing and managing the certification process for these identified buildings. 
If funding becomes available in FY 2013, INL will further enhance the Energy Star rating for the identified facilities and assist with overall energy reductions for the entire INL Site by installation of up to eight energy reduction projects at the SMC, MFC, and the Idaho Falls facility areas. These projects require an estimated $\$ 1.2 \mathrm{M}$ to construct and were developed during FY 2012 for implementation in FY 2013 with INL SIF.

1. SMC Air Handler Heat Recovery Loop

2. IAB Building Automation System and Lighting Controls

3. IORC Liebert System (9) Economizers

4. IF-603 VFCs and Controls

5. EROB Exterior Lighting

6. WCB Exterior Lighting

7. IRC Exterior Lighting

8. MFC Lighting Controls (500 Occupancy Sensors).

In FY 2013, INL will continue to develop additional projects for FY 2014 funding that will upgrade selected facilities in Table 3 to meet the Guiding Principles by the planned date. In addition, the CFA and ATR Complex buildings are targeted by ESPC Project 3 for Energy Conservation Measures (ECM) that will help these facilities meet the Guiding Principles.

The remaining 12 procedure oriented Guiding Principles will be documented for all buildings on Table 3 to achieve compliance by FY 2015.

Table 3. Buildings planned to meet Guiding Principles.

\begin{tabular}{|c|c|c|c|c|c|}
\hline Building & Metered & $\mathrm{iVu}$ * & $\begin{array}{c}\text { Water } \\
\text { Metered }\end{array}$ & $\begin{array}{l}\text { Guiding } \\
\text { Principle } \\
\text { Compliant }\end{array}$ & Comments \\
\hline REL & 2014 & 2014 & 2014 & 2015 & LEED $^{\mathrm{TM}}$ Gold in FY 2015 \\
\hline ESL & Yes & Yes & Yes & 2013 & LEED $^{\mathrm{TM}}$ Gold in FY 2013 \\
\hline IMCL & Yes & Yes & Yes & 2014 & LEED $^{\mathrm{TM}}$ Gold in FY 2013 \\
\hline IF-665 (CAES) & Yes & No & Yes & Yes & LEED $^{\mathrm{TM}}$ Gold \\
\hline IF-683 (RESL) & Yes & Yes & No & 2013 & LEED $^{\mathrm{TM}}$ Gold in FY 2013 \\
\hline $\begin{array}{l}\text { TRA-1608 } \\
\text { (TSB) }\end{array}$ & No & No & No & Yes & LEED $^{\mathrm{TM}}$ Certified \\
\hline $\begin{array}{l}\text { TRA-1626 } \\
\text { (TTAF) }\end{array}$ & Yes & Yes & No & 2014 & $\begin{array}{l}\text { Meets LEED }{ }^{\mathrm{TM}} \text { Certification } \\
\text { Except for Energy Use (further } \\
\text { analyzing for Energy Star score) }\end{array}$ \\
\hline IF-601 & Yes & Yes & No & 2013 & \\
\hline IF-602 & Yes & Yes & No & 2013 & \\
\hline IF-616 & Yes & Yes & Yes & 2013 & \\
\hline IF-654 & Yes & Yes & Yes & 2013 & \\
\hline IF-663 & Yes & Yes & No & 2013 & \\
\hline IF-680 & Yes & No & 2013 & 2014 & Water Meter by City of Idaho Falls \\
\hline IF-684 & Yes & No & 2013 & 2014 & Water Meter by City of Idaho Falls \\
\hline CF-1611 & Yes & Yes & No & 2013 & \\
\hline
\end{tabular}


Table 3. (continued).

\begin{tabular}{|l|c|c|c|c|l|}
\hline \multicolumn{1}{|c|}{ Building } & Metered & $\mathrm{iVu}$ & $\begin{array}{c}\text { Water } \\
\text { Metered }\end{array}$ & $\begin{array}{c}\text { Guiding } \\
\text { Principle } \\
\text { Compliant }\end{array}$ & \multicolumn{1}{|c|}{ Comments } \\
\hline CF-1612 & Yes & Yes & No & 2013 & \\
\hline CF-1618 & Yes & Yes & No & 2013 & \\
\hline CF-612 & 2013 & 2013 & No & 2015 & \\
\hline CF-615 & 2013 & 2013 & No & 2015 & \\
\hline CF-621 & Yes & Yes & No & 2015 & \\
\hline CF-623 & Yes & Yes & No & 2015 & \\
\hline CF-696 & 2013 & 2013 & No & 2015 & \\
\hline CF-698 & 2013 & 2013 & No & 2015 & \\
\hline MFC-710 & Yes & No & No & 2014 & $\begin{array}{l}\text { Need to Access ESPC Installed } \\
\text { Meter }\end{array}$ \\
\hline MFC-725 & Yes & No & No & 2014 & $\begin{array}{l}\text { Need to Access ESPC Installed } \\
\text { Meter }\end{array}$ \\
\hline MFC-782 & Yes & No & No & 2014 & $\begin{array}{l}\text { Need to Access ESPC Installed } \\
\text { Meter }\end{array}$ \\
\hline TRA-628 & 2013 & 2013 & No & 2014 & \\
\hline * iVu is a Carrier building control system through which INL tracks and compiles meter data. \\
\hline
\end{tabular}

\subsection{HPSB New Construction}

All new construction, major renovations, and alterations of buildings greater than 5,000 GSF must comply with the Guiding Principles and, where the work exceeds $\$ 5 M$, each are $L E E D^{T M}-N C$ Gold certification or equivalent.

The INL Site is implementing High Performance Sustainable practices and design specifications in new building design and construction by introducing High Performance Sustainable design criteria at conceptual design and following though during design and construction by using LEED $^{\mathrm{TM}}$ construction concepts and the Guiding Principles for High Performance Sustainable Buildings.

The INL Site also constructs buildings that are very mission specific and are not readily compatible with LEED ${ }^{\mathrm{TM}}$ or with the Guiding Principles. One new such facility is IWTU at INTEC that completed Conceptual Design (CD) Level 4 in FY 2012. Due to the mission of this facility and its energy use characteristics, the internal process at this facility will consume most of the metered energy. The IWTU was also at CD Level 2 before the LEED ${ }^{\mathrm{TM}}$ Gold requirement was implemented.

INL new construction includes DOE-owned and privately leased facilities. All existing leased facilities are privately owned. INL has no General Services Administration (GSA)-leased facilities.

\subsubsection{Performance Status}

Construction of the new Radiological and Environmental Sciences Laboratory (RESL) was completed in FY 2011 and LEED ${ }^{\mathrm{TM}}$ Gold certification is expected in FY 2013.

Construction was completed on the new IMCL in FY 2012 and is expected to be LEED ${ }^{\mathrm{TM}}$ Gold certified in FY 2013.

Construction was essentially completed on the new ESL in late FY 2012 and is expected to be LEED $^{\mathrm{TM}}$ Gold certified in FY 2013. 


\subsubsection{Planned Actions}

LEED $^{\mathrm{TM}}$ Gold certification is planned for the three facilities listed above in FY 2013. In addition, construction of the new REL is expected to be complete in FY 2013 with LEED ${ }^{\mathrm{TM}}$ Gold certification expected in FY 2014.

These four facilities will be assumed to be fully Guiding Principle compliant upon receipt of LEED ${ }^{\mathrm{TM}}$ Gold certification.

ICP has plans to renovate MFC-799 $\left(7,329 \mathrm{ft}^{2}\right)$, Sodium Treatment System, identified in ICP contract extension and is planned for startup by September 30, 2015, and MFC-793 $\left(3,809 \mathrm{ft}^{2}\right)$ planned for startup by September 30, 2016. Both are subject to Section I.81, Changes Clause in the ICP Contract Mod 231. Neither building will be subject to LEED ${ }^{\mathrm{TM}}$ design criteria, but both will be subject to implementing the Guiding Principles as far as is cost effective.

AMWTP does not project any new building starts within the remaining duration of the current contract.

\subsection{Renewable Energy}

$7.5 \%$ of annual electricity consumption from renewable sources by $F Y 2013$ and thereafter (5\% FY 2010-2012).

The INL Site continues to actively pursue Renewable Energy Generation capability and purchase of renewable energy through the local utility and is annually purchasing Renewable Energy Certificates (RECs) in amounts as outlined in the Energy Policy Act of 2005.

The goal for onsite renewable energy generation and direct purchase of new renewable electricity is not likely to be met due to the low cost of electricity from abundant older hydroelectric and coal sources and limited availability of renewable electricity from local utilities. The payback for renewable energy projects was evaluated during the development of ESPC Project 3 at 211 years for photovoltaic and 60 years for a single wind turbine. Onsite renewable energy generation is unlikely to be successful without supplemental funding to support such projects.

\subsubsection{Performance Status}

There is one solar transpired wall at the IRC Records Storage Facility. This wall preheats outside fresh air for the office area of this facility. Two other transpired solar walls were installed in FY 2010 as part of the MFC ESPC project. These solar walls provide renewable energy that avoids the use of conventionally generated electricity. Although solar walls avoid other energy use and are a renewable source, they do not contribute to meeting this goal.

The INL Site procured 22,000 MWh of Wind Generated RECs from Idaho Falls Power at a total cost of $\$ 22,000$. This preferential purchase of new renewable energy represents $9.9 \%$ of the INL Site's electric usage in FY 2011 and is the purchase for FY 2012.

\subsubsection{Planned Actions}

Low energy costs benefit the INL Site, allowing for increased strategic missions and facility enhancements. However, cost benefit analyses generally lead decision makers to place a lower priority on installation of renewable energy projects.

During ESPC contract negotiations, existing lease updates, and new lease negotiations, installation of renewable energy generation is considered and payback evaluated. The proposed ESPC Project 3 is unlikely to result in renewable energy generation projects (wind or solar) due to the cost and long return on investment. The Energy Savings Company was not able to identify any projects that would cumulatively produce the electricity necessary to meet the goal of $7.5 \%$ of INL Site electric use or even $3.75 \%$ onsite renewable energy generation. INL research and development (R\&D) continues to 
investigate the potential installation of numerous renewable energy technologies, but INL will not invest limited funding into renewable projects that are not economically viable or mission compatible.

The INL Site could meet the onsite renewable energy generation goal if funding is secured to support renewable energy installation on the INL Site. However, if funding is not obtained, the goal will not be met.

The INL Site will continue to meet minimum requirements of purchasing at least $7.5 \%$ of the electric energy usage in equivalent RECs. INL has committed to increase purchase of RECs starting in FY 2012 and thereafter to $10 \%$ of the INL electric usage. Although the increase does not contribute to the GHG reduction goal, it does demonstrate INL's commitment to climate change adaptation and strategic leadership. INL has also committed to maximize the purchase of locally generated Green Power RECs.

\subsection{REGIONAL AND LOCAL PLANNING}

Executive Order 13514 instructs federal agencies to meet the following regional and local planning goals:

- Participate in regional transportation planning and recognize existing community transportation infrastructure

- Align federal policies to increase the effectiveness of local planning for energy choices such as locally generated renewable energy

- Ensure that planning for new federal facilities or new leases includes consideration of sites that are pedestrian friendly, near existing employment centers, accessible to public transit, and emphasize existing central cities and, in rural communities, existing or planned town centers

- Identify and analyze impacts of energy use and alternative energy sources in all Environmental Impact Statements and Environmental Assessments for proposals for new or expanded federal facilities under the National Environmental Policy Act of 1969, as amended (42 U.S.C. 4321 et seq.)

- Coordinate with regional programs for federal, state, tribal, and local ecosystem, watershed, and environmental management.

\subsubsection{Performance Status}

As the INL Site primary contractor responsible for land management and sitewide leadership, INL maintains excellent relationships with local community planning and government groups, including the cities of Idaho Falls, Blackfoot, Arco, and Pocatello, as well as the counties of Bonneville, Butte, Bingham, and Bannock. Interactions include transportation infrastructure, facility planning locations, traffic patterns, and future infrastructure needs. When warranted, the community is involved and encouraged to supply feedback to decision makers during any National Environmental Policy Act public process.

Although limited, existing community transportation infrastructure usage is encouraged and INL works with multiple local and state agencies on transportation planning by providing input and sponsoring awareness events to promote employee-commuting ridership. In FY 2012, INL continued working with local transportation companies to coordinate a schedule for riders to the Blackfoot and Pocatello areas.

The bicycle remains a popular seasonal method of commuting at the Idaho Falls campus with increasing awareness of personal fitness and energy conservation. Facilities have designated bicycle spaces and INL continues to explore the possibility of covered parking for cycling and motorcycle commuters. 
Sustainable Site development encompasses an integrated approach during the refurbishment and planning of future onsite facilities and infrastructure, consistent with the INL TYSP. INL encourages walking and bicycling as means of travel within Site boundaries; long-range Site development envisions continuous improvement of a bicycle and pedestrian-friendly environment.

INL continues to work with the following local planning organizations:

- Idaho Strategic Energy Alliance

- Yellowstone Business Partnership (INL representative is on the Board of Directors)

- Yellowstone-Teton Clean Cities Collation

- Bonneville County Transportation Committee

- Targhee Regional Public Transportation Authority.

\section{FLEET AND FUEL MANAGMENT}

\subsection{Fleet Alternative Fuels}

\section{$10 \%$ annual increase in fleet alternative fuel consumption by $F Y 2015$ relative to an $F Y 2005$ baseline.}

The INL Site is developing diversified strategies for increasing alternative fuel consumption and reducing carbon emissions associated with light and heavy-duty vehicles. One of the DOE Order 436.1 transportation fuels goals is to increase the use of alternative fuels by $10 \%$ annually, as compared to the FY 2005 usage baseline. There are many opportunities to affect DOE's alternative fuel consumption by implementing fuel-switching activities at INL.

\subsubsection{Performance Status}

In FY 2012, the INL Site used 194,429 gasoline gallon equivalents of alternative fuels. This represents an increase of $154 \%$ over the FY 2005 use. These usages are a compilation of all INL Site contractors and the total of each of the various alternative fuels as reported into the Fleet Automotive Statistical Tool (FAST) database.

The INL Site is actively pursuing E-85 fuel and B20 usage. INL has increased the availability of E-85 and mandating its use while researching and implementing the use of B20 in the INL bus fleet throughout the year and across varied climate conditions.

Completed activities include:

- Increased the availability of alternative fuel by converting petroleum tanks to alternative fuel tanks and by encouraging the use of alternative fuel by all users of flex fuel vehicles.

- Updated the existing fueling infrastructure and provided additional alternative fuel locations to allow for improved fuel use tracking and control. Used a new technology, Radio Frequency Identification (RFID) fuel rings, also called "ring technology," making it easier to fuel INL vehicles by automatically capturing mileage and other data that employees once had to enter manually.

- Partnered with a local fuel distributor to make E-85 commercially available to east Idaho.

- Reported to flex fuel vehicle owners (quarterly) their percentage of E-85 usage compared to unleaded usage and encouraged the use of the appropriate flex fuel. This method of encouraging self-governing through information has led to increases in E-85 fuel use.

- Replaced the INL bus fleet with 52 new motor coaches that run on B20 and have improved fuel mileage by up to $50 \%$ ( $3 \mathrm{mpg}$ to $6 \mathrm{mpg}$ ). 
- Selected by GSA to receive three American Recovery and Reinvestment Act (ARRA) funded Parallel Hybrid drive shuttle buses to replace three 24-year-old buses. These new buses reduce petroleum use through greater efficiency and use B20. In FY 2012, the new buses were used on lightly loaded commuter routes and for shuttle and tour service.

- Researched methods to use B20 in the bus fleet year around.

Ongoing activities include:

- Continued efforts to right size the fleet with more flex-fuel vehicles capable of using E-85.

- DOE-ID and INL continued collaborating with the Yellowstone-Teton Clean Energy Coalition (local area Clean Cities program) to encourage and cooperate with local fueling stations and vendors to provide alternative transportation and fueling stations in the area.

- AMWTP has historically operated 89 passenger carrying light-use vehicles for transportation of personnel and goods to the desert site, though the fleet was reduced by 17 vehicles this year. The fleet consists of minivans capable of transporting up to six individuals. This small fleet averages over 2 million miles a year transporting approximately 500 personnel to and from car-pool locations in local community areas surrounding the INL Site.

- Each vehicle in the AMWTP fleet is an alternative fuel vehicle (AFV), and capable of using unleaded regular or E-85 as a fuel. Use of the Idaho Falls E-85 commercial fueling station continued through FY 2012. Employee commute vanpools based in Idaho Falls were requested by AMWTP management to use the E- 85 fuel. Initially, these actions resulted in approximately $50 \%$ of total fleet using E-85. For FY 2012 the annual utilization of E- 85 was approximately $23 \%$. The reduction in use of E-85 was directly attributed to reliability issues with the van fleet during the colder months (November through April). AMWTP did manage to reach 44\% utilization of E-85 during those months during which the region sees average low temperatures greater than the freezing point. In fact, the AMWTP fleet again exceeded 51\% utilization of E-85 during June of 2012. Were it not for winter reliability issues, AMWTP would continue to meet the $10 \%$ annual increase in fleet alternative fuel consumption by FY 2015 goal.

- Transferring a portion of the AMWTP workforce to the INL bus system represents an additional increase in the utilization of alternative fuels as some of the vans, which were removed from the fleet did not use E-85. Occupants transferred from those vehicles that did not use E- 85 are now carried by INL buses, which use B20.

\subsubsection{Planned Actions}

Additional increases in the use of alternative fuels will be obtained through numerous INL Site identified projects and activities that include:

- Continue researching the potential conversion of the INL bus fleet to alternative fuel types.

- Continue to track and trend reliability, fuel usage, and optimize performance of new B20 compatible buses while evaluating future purchases.

- Continue to encourage and establish process to stimulate the use of E-85 in flex-fuel vehicles at the end user level. This includes individual goal setting at an organization level and holding individuals accountable for non E-85 fuel purchases.

- Replace fleet heavy trucks and equipment with new equipment that will run on B20. 


\subsection{Fleet Petroleum Fuels}

$2 \%$ annual reduction in fleet petroleum consumption by FY 2020 relative to a FY 2005 baseline.

The INL Site is developing diversified strategies for reducing fossil fuel use and carbon emissions associated with light and heavy-duty vehicles. One of the DOE Order 436.1 transportation fuel goals is to reduce petroleum fuels by $2 \%$ annually through FY 2020 ( $30 \%$ total reduction), as compared to the FY 2005 usage baseline. There are many opportunities to affect DOE's petroleum fuel usage by implementing fuel reduction and fuel switching activities at INL.

\subsubsection{Performance Status}

In FY 2012, the INL Site used 747,777 gasoline gallon equivalents, a 20.3\% reduction from FY 2005. This usage is a compilation of all INL Site contractors and the total of gasoline and diesel fuels as reported into the FAST database.

Completed activities include:

- Increased overall bus efficiencies by implementing express routes and eliminating underutilized routes. This was in conjunction with continued efforts in right sizing the fleet with more flex-fuel vehicles and hybrids.

- Incorporated the Park and Ride concept to reduce bus fuel usage, and developed additional Park and Ride lots for employees at outlying locations.

- Used innovative technology to track and reduce fuel usage such as Global Positioning System (GPS), RFID fuel rings, and data logger technology to monitor engine performance and driver habits.

- Replaced the INL bus fleet with 52 new motor coaches that run on B20, and have improved fuel mileage by up to $50 \%$ ( $3 \mathrm{mph}$ to $6 \mathrm{mph}$ ).

Ongoing activities include:

- Continue research methods to use biodiesel blends in the bus fleet year around, reducing the need for $100 \%$ diesel.

- Continue the Reduce Idle Campaign that is saving fuel by better managing idling times. Results are positive as this campaign is saving 1,400 gallons of fuel per month.

- Continued efforts to right size the fleet with more fuel-efficient vehicles.

- As AMWTP has operated its van pool commuter fleet to meet alternative fuel use goals, it has also contributed to a corresponding reduction in petroleum fuel use. Additionally, as noted in Section 3.4, the reduction of the AMWTP fleet represents a sizeable reduction in the use of traditional petroleum fuels.

\subsubsection{Planned Actions}

Additional reductions in petroleum-based transportation fuels will be obtained through numerous INL Site identified projects and activities that include:

- Add one additional Park and Ride location to further reduce employee commute and bus fleet fuel usage.

- Anticipate a reduction in petroleum usage as AMWTP comes to a close. Additionally, several pieces of heavy equipment will be consolidated further to reduce vehicle inventory and fuel usage.

- Evaluate technology that will allow INL to operate the bus fleet on "mixed" fuel, which is a combination of CNG and biodiesel. This may allow INL to reduce fuel usage by up to $30 \%$. 
- Implement Federal Commuter Tax Credit for employees who chose to carpool to work. Continue to encourage the use of teleconferencing and trip consolidation to reduce miles traveled.

\subsection{Fleet Vehicle Purchases}

$75 \%$ of light-duty vehicle purchases must consist of alternative fuel vehicles (AFV) by FY 2000 and thereafter.

INL procures light-duty fleet vehicles almost exclusively through the GSA vehicle-leasing program. Maximizing the use of this GSA program is at the forefront of INL plans to achieve this goal. A rotation schedule based on vehicle age and mileage determines when vehicles are returned to GSA. When currently allocated vehicles are due for replacement, the old vehicle is replaced with an AFV or hybrid vehicle from GSA. There are currently very few exceptions for receiving conventional vehicles. Examples include some emergency response vehicles and heavy-duty full-size pickups. However, DOE Headquarters (HQ) has directed that hybrid vehicles (which are not AFV vehicles at this time) be procured when available. This greatly impacts the $75 \%$ AFV target.

\subsubsection{Performance Status}

The INL light-duty fleet is comprised of 378 vehicles of which 55 are AFV, 209 are E-85, and 58 are gas/electric hybrids. The INL Site acquired nine light-duty vehicles in FY 2012, all of which are flex-fuel $(100 \%)$, none are hybrid, and none are gasoline.

The INL light-duty fleet was reduced an additional 13 vehicles for cost reduction and through fleet rightsizing initiatives.

An all-electric Polaris Ranger was tested at two remote locations for feasibility and practicality as a replacement for different brands of Utility Terrain Vehicles (UTV). The test was successful as operators enjoyed the quiet ride and power. Finding an outlet for recharge was occasionally difficult, but once locations were identified it became inconsequential. Early indications also point to lower maintenance costs. The purchase price of $\$ 16 \mathrm{~K}$ places this model at the top of the UTV price range and may take years to recoup the savings the all electric models provide.

\subsubsection{Planned Actions}

A survey will be sent out to all INL light vehicle custodians to ensure the vehicle is being used in accordance with the vehicle justification form. This survey will help ensure accurate information is gathered and mission critical vehicles are excluded from ongoing vehicle reductions measures. The goal is to reduce the light-duty fleet further by approximately 100 vehicles.

\subsection{Fleet Inventory Sizing}

\section{Reduce fleet inventory by $35 \%$ within the next 3 years (end of FY 2013) relative to a FY 2005 baseline.}

\subsubsection{Performance Status}

The INL Site and DOE-ID committed to meet the 35\% reduction goal by FY 2013 and met the goal one year early, reducing vehicle inventory by 148 units.

In January 2012, INL entered into a partnership with GSA to acquire 52 new buses. The buses started arriving in March. With the addition of the 52 new GSA-leased buses, INL eliminated 52 owned, inefficient buses from the fleet and increased capacity from 44 passenger buses to 55 passenger buses. The reliability of the new buses allowed INL to reduce the number of spares buses kept "road ready" during starting and maintenance issues. 
INL was able to reduce the heavy equipment pool by 60 pieces of equipment. This was accomplished through monitoring equipment usage, fleet equipment advisory group input, and using the J-hook heavy truck system of using multiple beds for one truck.

AMWTP reduced its van fleet by 17 vehicles during the fiscal year by transferring a portion of the workforce residing in Idaho Falls to the INL bus system. This represents nearly a $20 \%$ reduction in the size of the AMWTP van fleet as the INL bus system did not need to add vehicles to accommodate the addition of this portion of the AMWTP workforce.

\subsubsection{Planned Actions}

INL will allocate the majority of equipment to the end user except for a small centralized fleet of approximately 100 pieces of equipment. In doing so, the custodian will be accountable for cost, acquisition, maintenance, and storage of the equipment. However, Fleet Management will maintain input on all equipment acquisitions.

INL is planning a strategic reduction of 100 vehicles (20\%) in FY 2013 to better reflect mission need, resolve budget challenges, and support complex wide goals.

\section{WATER USE GOALS \\ 4.1 Water Use Reductions}

\section{$26 \%$ water intensity reduction by $\mathrm{FY} 2020$ from a FY 2007 baseline}

The INL Site's goal for water usage is a $16 \%$ reduction of usage intensity by FY 2015 , or $2 \%$ each year, as compared to the FY 2007 Water Usage Intensity Baseline measured in gallons per square foot $\left(\mathrm{gal} / \mathrm{ft}^{2}\right)$.

Due to the nature of the various INL Site missions, many of the operations can be cyclical and result in varying usages of water throughout the year and from year to year. In addition, as facilities are removed and processes are shut down, the lower square footage can actually result in an increase in water use intensity even as overall water usage is reduced.

The water intensity reduction goal will be very difficult for the INL Site to accomplish. Long payback calculations based on inexpensive water and electric rates make water saving projects cost ineffective. Water usage is so dependent upon process usage and events or activities such as wildfires and D\&D or construction work, that this goal will be very difficult to obtain.

\subsubsection{Performance Status}

As per the water reduction goals found in DOE 436.1, the INL Site should be at a $10 \%$ water intensity reduction at the end of FY 2012 when compared to the FY 2007 Reportable Water Usage Baseline. The INL Site used a total of 858.9 million gal of water in FY 2012, resulting in a water usage intensity of $154.0 \mathrm{gal} / \mathrm{ft}^{2}$, a decrease of $11.4 \%$ over the FY 2007 baseline $\left(173.9 \mathrm{gal} / \mathrm{ft}^{2}\right)$. However, as demonstrated through water use and building square footage data entered into the CEDR, the INL Site total water used has decreased from 1,050.9 million gal in FY 2007 to 858.9 million gal in FY 2012, for a total water used reduction of $18.3 \%$.

Construction was completed on the new ESL facility, which incorporated significant xeriscaping, efficient water fixtures, and water sub-metering. This facility is expected to be a low water user and help to lower the INL Site water use intensity. In addition, all water fixtures in the IRC Office Building (IF-602) were replaced with new low-flow fixtures. 


\subsubsection{Planned Actions}

Other projects that will continue to contribute to water use reductions for the INL Site include several ongoing tasks:

- Leak analyses will continue at all areas of the Site.

- INL and ICP will continue purchasing Environmental Protection Agency WaterSense or other water efficient products, which will be documented by Sustainable Procurement processes.

- ESPC Project 3 planned for CFA and the ATR Complex may eliminate once-through HVAC cooling water, increase efficiency through fixture replacements, locate and repair leaking water lines, and possibly reduce industrial water use at the ATR Complex.

- The new REL facility in Idaho Falls is scheduled to be completed in 2013. This LEED ${ }^{\mathrm{TM}}$ Gold facility, similar to the ESL, should be a low water user by incorporating xeriscaping concepts and low-flow water fixtures while adding over $239,000 \mathrm{ft}^{2}$ of space to the water intensity calculation.

- EM missions, as noted in the CEDR, will contribute to water reductions as facility missions are complete. These include the AMWTP complex of facilities being cold, dark, and dry.

Based on the previous cost of the MFC ESPC that resulted in a 5\% water reduction and the proposed ESPC at the ATR Complex and CFA, additional water reduction implementation at the INL Site could cost between $\$ 40 \mathrm{M}$ and $\$ 50 \mathrm{M}$. Projects include:

- Replace all high-water use faucets, toilets, showerheads, and urinals across the INL Site.

- Upgrade ATR cooling tower.

- Detect and repair underground leaks.

- Re-route ATR Complex air compressor cooling water disposal paths.

- Reduce ATR Complex sewage lagoon size.

- Replace all inefficient domestic hot water heaters across the INL Site.

\subsection{ILA Water Use Reductions}

$20 \%$ water consumption reduction of industrial, landscaping, and agricultural (ILA) water by FY 2020 from a FY 2010 baseline.

ILA water is not applicable to the INL Site. All water obtained by the INL Site is obtained from the Snake River Plain Aquifer and is potable. The INL Site does not have access to any non-potable water supplies.

\subsubsection{Performance Status}

N/A.

\subsubsection{Planned Actions}

N/A. 


\title{
5. WASTE MINIMIZATION \\ 5.1 Landfill Waste Diversion
}

\author{
Divert at least $50 \%$ of non-hazardous solid waste, excluding construction and demolition debris, by \\ FY 2015.
}

"The INL Site Pollution Prevention Plan" (DOE/ID-10333) describes the pollution prevention practices pursued at the INL Site. INL continued the co-mingled recycling and paper shredding programs at the desert site facilities (CFA, MFC, and ATR Complex) during FY 2012. INL is also working with INL Site contractors to expand co-mingled recycling at other site facilities. All INL employees are capable of participating in the co-mingled recycling program that allows employees to place a variety of recyclable materials into one collection bin. ICP also has co-mingled recycling at town facilities and paper recycling at the desert site facilities. Additionally, ICP is working on implementing co-mingling at INTEC in FY 2013 and is pursuing composting waste diversion for ICP cafeteria consumables.

With the exception of SMC, all town and desert site employees have the option to participate in the paper shredding recycling program, which includes regular office paper and controlled unclassified information (CUI) materials for shredding. In FY 2012, INL facilities recycled 219,256 lbs of co-mingled materials and 402,820 lbs of office paper and cardboard. Additionally, INL diverted or recycled another $401,055 \mathrm{lbs}$ of materials, including scrap metal, wood, cooking oil, compostables, and wood pallets. This accounts for approximately $32.8 \%$ diversion of municipal solid wastes collected at INL facilities.

The INL Site continues to utilize a number of processes to reduce the quantity and toxicity of hazardous chemicals. The processes follow the simple reduce, reuse, and recycle steps to help achieve the overall goal. The INL Site utilizes chemical coordinators and environmental personnel to help ensure the requested materials are actually needed, are not available through an exchange/sharing program, and the smallest/most appropriate quantity is being ordered. INL also stipulates the use of Massachusetts Institute of Technology (MIT) Green Chemical alternatives list at (http://web.mit.edu/environment/academic/alternatives.html) to help chemical coordinators identify "greener" alternatives to chemicals being requested. Researchers at the IRC are networked together by the chemical coordinator if one researcher needs a small quantity of a particular chemical that already exists at INL. This program helps ensure that the chemicals are used for the intended purpose, ensures continuous turnover of the inventory, reduces the time to get a chemical, and saves the researcher money in not having to purchase a chemical. Chemical coordinators actively search for existing inventory to preclude new purchases. INL also participated with other national laboratories to establish a chemical reduction guidance that will outline more specific steps and reduction goals for INL. INL has also worked with Procurement to screen subcontractor's procurement requirements to ensure that less-hazardous chemicals are utilized when available and life-cycle costs are considered prior to purchase. INL and ICP are working actively and continually towards improvement in reduction of inventories through the avenues of acquisition, use, and disposal.

The INL Site Hazardous Waste Management Act (HWMA)/Resource Conservation and Recovery Act (RCRA) Permit requires that all operating contractors conduct and complete a source reduction evaluation review and written plan, in accordance with the procedures and format provided in the "EPA Waste Minimization Opportunity Assessment Manual" (EPA/625/7-88/003). This review and plan was submitted to the Idaho Department of Environmental Quality on March 31, 2011 and every 4 years thereafter, and must include detailed descriptions of any programs the contractors may have to assist generators of hazardous and mixed waste in reducing the volume (quantity) and toxicity of wastes produced.

AMWTP reduces and minimizes the quantity and toxicity of hazardous chemicals and materials through a procurement process that stresses environmentally preferable purchases. One of the objectives stated in the AMWTP management procedure for the acquisition of material and services is to use 
recycled-content and bio-based content materials and other environmentally preferable products and services to the maximum practicable extent. Purchase requisitions are screened by an assigned procurement specialist for environmentally preferable materials.

AMWTP has also evaluated possibilities with the use of Value Engineering activities throughout the year to identify materials that have been initially dispositioned for disposal to determine whether such materials would be suitable for re-use onsite for changes in production. One example of this is the intended re-use of over 1,000 metal pallets for construction of modified six drum overpack (SDOP) containers.

\subsubsection{Performance Status}

As reported in the Pollution Prevention Tracking and Reporting System (PPTRS), the INL Site diverted 33.1\% (527 Metric Tons [MT]) of its non-hazardous solid waste in FY 2012. INL diverted 33\% (464.1 MT) of municipal solid waste from the landfill in FY 2012. ICP diverted 29\% (41.4 MT), and AMWTP diverted 29\% (21.6 MT) of municipal solid waste from the landfill in FY 2012.

INL implemented an interactive drag and drop recycling quiz that was incorporated into the all employee Environment, Safety, and Health (ES\&H) refresher training and was placed on the Recycling Program's internal website. A recycle champion award was awarded quarterly to nominated employees for their enthusiasm and participation in the recycling program. INL Dining Services began recycling the used cooking oil through a vendor in FY 2012.

Midway through FY 2012, an interactive display was placed in the new "Dynamic Learning Center." The display is intended to provide a "hands-on" experience to all new employees with a follow-up assessment of material learned. This center is also open to all employees by appointment. INL attempted to revisit the cafeteria waste composting pilot during the summer of FY 2012, since efforts conducted in FY 2011 did not produce viable compost. Weather conditions, distance between facilities, and lack of volume may prohibit small-scale composting to be conducted onsite. Further evaluation and funding availability will be necessary before a composting program could be implemented.

\subsubsection{Planned Actions}

The INL Site will continue to educate and encourage employees to participate in the recycling and paper shredding programs in town and at the industrial campuses.

The INL Site will continue to evaluate potential outlets and the expansion of recyclable waste streams, such as mulching mowers, toner cartridges, fluorescent light tubes, batteries, and food wastes, to increase further the amount of wastes diverted from the landfill.

The INL Site will continue to reduce printing paper used through a campaign for users to set printers and copiers to duplex printing. Centrally managed printing will be evaluated.

The INL Site anticipates meeting this goal if funding is allocated to optimize the current waste diversion systems, modify contracts, and markets are available to divert waste streams.

\subsection{Construction and Demolition Waste Diversion}

\section{Divert at least 50\% of construction and demolition materials and debris, by FY 2015.}

INL has incremental goals for construction and demolition waste, increasing $10 \%$ per year from 2011 through 2015.

The diversion of construction and demolition debris during D\&D activities for ICP is often problematic due to the potential for radioactive contamination. Diversion of D\&D waste is often quite costly and the wastes are usually disposed of onsite. 


\subsubsection{Performance Status}

The INL Site diverted 29.6\% of its construction and demolition (C\&D) in FY 2012 (3,971 MT).

Construction waste and landfill acceptance data is analyzed quarterly to track performance against the goals. INL diverted 3\% (67 MT) of C\&D waste during FY 2012. This included C\&D soil reused as landfill cover and asphalt regeneration. ICP diverted 6\% (165 MT) of C\&D waste in FY 2012. AMWTP diverted 44\% (3,738 MT) of C\&D waste in FY 2012, the majority of which was soil reuse.

\subsubsection{Planned Actions}

INL intends to perform the following actions to enhance the C\&D waste diversion process:

- Incorporate metals recycling into D\&D tasks when allowed under the current recycling moratorium

- Continue analyzing the conditional waste stream to develop better segregation and reuse strategies

- Engage construction subcontractors to solicit best practice ideas relative to the INL logistics and market potential.

\section{SUSTAINABLE ACQUISITION}

\subsection{Sustainable Acquisition}

Procurements meet sustainability requirements by including necessary sustainable provisions and acquisition clauses (95\% each year).

DOE's SSPP commits to the following sustainable acquisition goals:

- Ensuring $95 \%$ of new contract actions, including task and delivery orders under new contracts and existing contracts, require the supply or use of products and services that are energy efficient (ENERGY STAR or FEMP-designated), water efficient (WaterSense), biobased, environmentally preferable (including Electronic Product Environmental Assessment Tool [EPEAT]-registered products), non-ozone depleting, contain recycled content, or are non-toxic or less-toxic alternatives.

- Updating departmental sustainable acquisition plans (previously known as green purchasing plans or environmentally preferable purchasing plans), policies, and programs to ensure that all federally mandated designated products and services are included in all relevant acquisitions.

\subsubsection{Performance Status}

The INL Site did not meet the $95 \%$ sustainable provisions goal. ICP was not contractually obligated to track this number in FY 2012; however, ICP is now required to implement, track, and report this data in FY 2013. INL reports indicate $71 \%$ of the contracts in FY 2012 contained applicable clauses. This does not meet the goal, but changes to contract acquisition systems are time intensive and costly with little benefit to contracts that are service based. However, INL made improvements in incorporating requirements through effective implementation of procedures, clauses, policies, and enhanced work processes that increase the visibility, availability, and use of sustainable products.

- INL continued to make progress incorporating additional and revised sustainable acquisition language into contracts

- INL will continue to use commodity codes related to sustainable acquisition products to reduce the number of purchases greatly that require further review in an effort to enhance automated tracking and reporting within the current system.

- Preference program: INL's automatic document generation system was used to further incorporate in applicable contracts additional and revised sustainable acquisition language. For example, INL requires its supplier of standard desktop computers to provide items designated as EPEAT Silver or better. 
- Estimation, Certification, and Verification: INL requires suppliers (e.g., construction services, office products, paper products, janitorial products) to deliver spend reports listing the designated versus preferred purchases. In addition, INL has developed standard reports that provide the summary data necessary for reporting spend for recycled content products and janitorial products.

- Annual Review and Monitoring: INL conducts an annual review and assessment of a specific aspect of the sustainable acquisition program.

- Sustainable acquisition requirements prior to FY 2011 were incorporated in DOE-ID major site contracts.

AMWTP has begun integrating sustainable acquisition clauses, new to the current contract, into a Sustainable Acquisitions Program, which will be implemented through procedures and roll downs into applicable subcontracts.

\subsubsection{Planned Actions}

In recent years, there continued to be many changes and additions in sustainable acquisition requirements. INL plans to perform the following actions to improve its sustainable acquisition program:

- Develop appropriate mechanisms to augment the existing reporting requirements and track compliance with this goal

- Enhance the current ordering system to increase sustainable acquisition visibility to the laboratory community

- Ensure personnel resources are adequate and aligned in accordance with the proper organizational roles and responsibilities

- Conduct a campaign to increase the education and awareness of sustainable acquisitions and their effect on certain INL performance requirements

- Benchmark processes with other laboratories to leverage lessons learned and to discover potential improvements to INL's process.

\section{DATA CENTERS AND ELECTRONICS STEWARDSHIP 7.1 Data Center Metering}

All data centers are metered to measure a monthly Power Utilization Effectiveness (PUE) (100\% by FY 2015).

The INL Site has four data centers. The first is INL's IORC, which is the primary location for the business enterprise servers and data repository. This data center hosts business systems, e-mail, project applications, and the primary business infrastructure systems for INL. The second data center is in EROB and is the location for the High Performance Computing (HPC) servers and storage.

ICP has two small data centers, one in Idaho Falls at IORC and the other at the desert site.

\subsubsection{Performance Status}

The HPC data center in EROB was metered when constructed in FY 2007. In FY 2011, these meters were connected to INL's i-Vue building control system in order to visually display real-time power consumption and automatically calculate PUE. Additionally, the IORC data center is now metered separately and uses the i-Vue system to trend and track data.

\subsubsection{Planned Actions}

Both data centers are metered separately from the remainder of their respective facilities. INL will continue to monitor, trend, and track data from each meter to ensure accuracy and validate PUE. 


\subsection{Data Centers PUE Measurement}

\section{Maximum annual weighted average Power Utilization Effectiveness (PUE) of 1.4 by FY 2015.}

\subsubsection{Performance Status}

The IORC data center PUE calculates at an average of 2.03 .

The EROB data center PUE has an average calculation of 1.34 .

The ICP data centers were added in FY 2012 based on the updated data center definition. Plans are being developed to track, trend, and report data center PUE in the future.

Several operational adjustments were made in FY 2012 to improve the overall efficiency of the HPC data center.

- Prior to FY 2012, the Computer Room Air Conditioning (CRAC) unit fans were configured to operate at a variable speed that produced an inconsistency in airflow throughout the data center. Sections of the data center, depending on the size and usage of computer equipment, were much warmer than other areas. To provide better air flow and achieve a more uniform room temperature, the CRACs were set to a constant fan speed, which has helped produced a more uniform temperature.

- The operating room temperature was increased $7^{\circ} \mathrm{F}$, from $68^{\circ} \mathrm{F}$ to $75^{\circ} \mathrm{F}$.

- Intelligence was programmed into CRAC units and chillers to allow the chilled water supply temperature to be adjusted dependent upon the heat generated by the computer systems (i.e., as the load increases on the computer systems they generate more heat, requiring more cooling and vice versa). The CRAC units now sense that need and open their valves wider, which tells the chillers that more cooling is required and they decrease the temperature of the water supply. The chilled water supply had been hard set to $43^{\circ} \mathrm{F}$; with this change, the average required temperature has increased $3^{\circ} \mathrm{F}$ to $5^{\circ} \mathrm{F}$, which decreases the power consumption of the chillers.

- Two additional modifications were made that will improve the overall performance of the chiller plant, though not necessarily decrease PUE. The chillers and cooling towers, two of each, had been previously operating in solely a redundant mode (i.e., the second one would only be used in event of a failure of the first). The plant has been reprogrammed to operate using both chillers and both cooling towers as the load requires, while maintaining the lowest possible power consumption to meet the cooling demands.

In addition, to achieve greater operational efficiency, Information Management (IM) has embraced numerous emerging technologies within the two INL data centers by the following industry standard practices:

- Virtualizing and consolidating servers. Currently, more than half of INL servers are running in a virtual environment.

- Investing in new high-efficient server and uninterruptable power supply (UPS) hardware and replacing the legacy systems.

- Implementing facility best practices to reduce energy use.

- Redesigning data centers and establishing hot and cold aisles to decrease air conditioner usage.

- Removing old cabling under the floor to improve airflow.

- Investigating using newer network equipment that will utilize higher bandwidth with less equipment and port needs (Cisco Nexus).

- Purchasing Energy Star rated equipment where applicable. 


\subsubsection{Planned Actions}

Virtual Machine (VM) Server Farms. INL IM will promote the use of virtual servers (one physical server computer which may use several virtual instances of server computers) wherever possible in place of single-purpose servers.

VM Desktops. IM will promote the use of virtual desktops on one physical desktop computer for users who need to use several different operating systems.

Desktop Refresh Initiative (DRI). When the end of the year overall INL budget allows, IM will also facilitate the desktop refresher initiative that purchases newer, more efficient computers to replace older wasteful desktop computers and laptops.

As part of ongoing activities, IM will continue to upgrade and consolidate servers. Additional planned activities include popular data center practices such as increasing the data center room temperature by approximately $10^{\circ} \mathrm{F}$. This by itself should provide further savings without additional risk. The data center control system is a "Carrier" system with a large number of monitoring and control points. This system will be further enhanced to provide better day-to-day monitoring, trending, and reporting. Other options are being considered such as powering down unused computer nodes to save additional power.

\subsection{Electronic Stewardship}

Electronic Stewardship - 100\% of eligible PCs, laptops, and monitors with power management actively implemented and in use by FY 2012.

\subsubsection{Performance Status}

The INL Site has been a partner in the Federal Electronics Challenge (FEC) since FY 2007. INL's participation in the FEC is supported by representatives from procurement, information management, property management, and environmental support services. Through continuous improvement, INL has emerged as a leader in electronics stewardship as evidenced by winning the FEC Bronze award in FY 2007, FY 2008, and FY 2011, and the FEC Silver award in FY 2009, FY 2010, and FY 2012. More specifically:

- INL currently has both a policy and procedure that covers the responsibility and directions for implementing and maintaining power management on PCs and monitors, and shutting down PCs (and peripherals) when not in use. The lab-wide procedure covers $100 \%$ of IM managed systems and excludes sensitive and mission-critical equipment. It also calls for owners of self-managed systems to implement the "company-standard" power management settings.

- IM continues to use a centrally managed configuration tool (LANDesk) to set and maintain power management settings on all Information Technology (IT)-managed and jointly managed computers. Administrators of self-managed computers (computers that are not manageable with LANDesk) are given instruction on how to set the power management settings on their computers. Exemptions from these power management settings are tracked in IM's Remedy database and are approved after valid business justifications for exemptions are provided.

- All network printers were set to duplex default in FY 2011. In FY 2012, the maintenance contract for copiers was modified to include setting all copiers to duplex default. All networked printers are required to support duplex printing as part of INL's printer standards, and efforts were started in FY 2012 to start using managed print services.

- INL promotes the standard for new electronic equipment and hardware to be a minimum of Energy Star 5.0 Category B rating and wherever possible, Category A Energy Rating. Dell Energy Smart is enabled from the manufacturer. Dell eSMART settings are used wherever possible.

- In FY 2012, 93.7\% of desktops were FEMP Low Power Standby Compliant. 
- In FY 2012, 98.6\% of office-based desktops, notebooks, workstation desktops, and workstation notebooks and $97.7 \%$ of office-based computer displays were EPEAT registered. The INL standard for procurement of desktop computers, workstations, and laptops is to meet or exceed EPEAT Silver and wherever possible, EPEAT Gold standards.

- INL property services reuses computers and other electronics through disposal via reutilization, donations, transfers, and sales. These methods meet the GSA definition for recycling electronic property, resulting in over $99 \%$ reuse during FY 2012.

ICP also partnered in the FEC and was awarded the FEC Bronze award in FY 2011. Several energy saving activities are in place. Power management settings are available on personal computer systems. Network copiers were set to duplex default in FY 2012.

It is AMWTP's policy to procure only Energy Star compliant computer monitors with Energy Star power management features enabled as part of the standard load. The AMWTP IT Infrastructure Group has an established policy stating that all eligible computers and monitors must have Energy Star features that allow AMWTP to comply with the DOE's mission while ensuring effective energy conservation. The Group has implemented configurations and mechanisms on eligible systems to execute energy conservation measures automatically. Certain production and plant operations systems were excluded from this policy (i.e., control room systems and camera monitors, as those systems are safety and operations related and must remain in the "on" position). AMWTP employees are prevented from making changes to these settings by cyber security policies that are in place on all AMWTP systems.

\subsubsection{Planned Actions}
INL Site planned actions for FY 2013 include:

- Continue to focus efforts that are cost effective and least disruptive to performers and will continue to work with IM and procurement to improve electronic stewardship.

- ICP will set network printers to duplex default in FY 2013. Desktop configuration hardware is in compliance with Energy Star and DOE standby power requirements.

- INL will achieve the FEC Gold award level for FY 2013 activities.

\section{SITE INNOVATIONS}

INL is a science-based applied engineering national laboratory whose mission is to "ensure the nation's energy security with safe, competitive, and sustainable energy systems and unique national and homeland security capabilities." INL pursues this mission by conducting research, development, and demonstration activities to help speed the deployment of clean energy technologies, improve the management of energy-related materials, and reduce the environmental consequences of energy development.

INL is one of DOE's three recognized "energy" laboratories, and is the lead laboratory for nuclear energy research and development. In addition to the nuclear mission, INL also conducts research on advanced energy system component integration and system design and analyses comprising the following elements: (1) process modeling and analysis, (2) feedstock production and processing, (3) energy integration and heat transfer, (4) energy storage and product synthesis, (5) byproduct management, (6) process and system monitoring, control, and maintenance. INL's R\&D program integrates engineering models with testing, instruments, monitoring, and control schemes to support optimal energy systems design, energy resource optimization, total carbon/water management, and hybrid energy systems. INL has recognized applied science and engineering leadership in the following clean energy specialty areas:

- Development and demonstration of biofuels feedstock technology

- Testing and demonstration of advanced battery technology 
- Protection and testing of critical infrastructure

- Through the Center for Advanced Energy Studies (CAES), evaluation of energy efficiency technology to determine best practices for energy efficiency deployment

- Design and testing of hybrid energy systems for increased utilization of renewable energy and production of low carbon synthetic fuels

- Geothermal resource characterization, systems engineering, and energy recovery

- Transportation and safe management of nuclear materials

- Water resource sustainability and climate change adaptation.

The INL Site is deploying energy sustainability technologies that build on advances made by these energy research programs. INL is pursuing site innovation in three major areas: vehicles, building energy usage, and environmental sustainability.

\subsection{Vehicles}

INL is supporting efficient, low carbon vehicle site innovations in three ways. For heavy vehicles such as buses and heavy trucks, INL is purchasing alternative fuel vehicles that have higher fuel efficiency than prior units and can operate on B20. Deployment of alternative fuel vehicles is consistent with developing a market for biofuels, and opens up opportunities to use the INL Bioenergy Program's process demonstration unit (PDU) and the hybrid energy systems facility to integrate renewable electricity generation and regional biomass production to increase simultaneously utilization of alternative low-carbon fuels while increasing utilization of renewable energy. INL is also purchasing light-duty vehicles that have higher fuel economy, can use alternative fuels, and operate on electricity. This innovation is synergistic with INL's battery testing program, and has the capacity to expand INL's usage of renewable energy. Utilization of electric vehicles also has potential synergy with INL's critical infrastructure protection facility; as such, a facility could be teamed with hybrid electric vehicles to investigate how large-scale utilization of electric vehicles could impact the security of urban electric systems and/or enhance utilization of renewable electricity.

\subsection{Building Energy Usage}

INL is building upon our programs in energy efficiency to lead the region in the deployment of sustainable buildings that meet the U.S. Green Building Council's LEED ${ }^{\mathrm{TM}}$ certification. Of INL's existing buildings, the CAES has achieved a $\operatorname{LEED}^{\mathrm{TM}}$ Gold certification. Two new buildings that are currently under construction, the ESL and the RESL will also be LEED ${ }^{\mathrm{TM}}$ certified, with the RESL building to be LEED ${ }^{\mathrm{TM}}$ Gold certified. INL is also deploying solar generation where practicable, and is investigating the potential to utilize geothermal resources to improve energy sustainability. Groundsource geothermal heat pumps are currently being investigated as an option for providing renewable heating and cooling services. INL is also developing plans to operate an Enhanced Geothermal Systems (EGS) test and demonstration facility at the INL Site, which is located in one of the United States' most promising areas for geothermal resource development. If realized, the EGS test facility could also support site innovation for producing renewable energy to support site operations. 


\subsection{Environmental Sustainability}

INL is also building upon laboratory nuclear and environmental research programs to discover new ways to utilize site operations to support environmental sustainability goals. As the nation's lead nuclear laboratory, INL produces small amounts of radiologic waste material during our research operations. Most of this radiologic waste is produced at the ATR Complex and NRF. INL is in the process of designing and constructing a new radiologic waste facility to support these operations. This work is being funded out of the INL site operations budget, and has provided innovative new solutions to the environmental challenges of radiologic waste management. In this case, site operations are helping to advance an essential aspect of INL's R\&D mission to advance civilian nuclear power as a clean energy alternative.

INL is also finding synergies between site operations and INL's R\&D mission in the area of climate change adaptation and the future availability of water. INL's Mountain West Water Institute (MWWI) hosts a regional forum on how to address regional water sustainability issues, including water security, energy impacts on water resources, and the future availability of water. Through these forums, the MWWI helps regional stakeholders to learn about the water challenges and share ideas and case studies on how to resolve these issues. INL site operations are integral to this, as INL hosts one of the largest areas of controlled-access, minimally disturbed land in the western U.S.. Researchers at the United States Geological Survey and regional universities use INL property as a test bed to improve INL understanding of the relationships between climate, water, land management, and fire risk; and are also engaged in the MWWI initiative. This synergy provides a strong example of how INL site operations and INL research operations are working together to help regional stakeholders and agencies meet sustainability goals.

\section{BUDGET/FUNDING}

\subsection{Energy Savings Performance Contracts (ESPC) Projects}

INL has three active ESPC projects, the first at the IRC Complex was completed in FY 2002, the second project at the MFC Complex was completed in FY 2010, and a third project is being developed for the CFA and ATR Complex areas.

- ESPC Project 1 included lighting and primary transformer upgrades at the IRC Complex for an installed cost of $\$ 779 \mathrm{~K}$, and is in Year 11 of a 19-year contract term.

- ESPC Project 2 included boiler and compressor replacements, lighting and HVAC upgrades, and solar wall installations at the MFC Complex for an installed cost of $\$ 33 \mathrm{M}$ and is in Year 2 of a 16year contract term.

- ESPC Project 3 is being developed primarily for the CFA and ATR Complex areas and will include lighting and HVAC upgrades, control systems upgrades, boiler system replacements, and a potential solar wall installation. This project is expected to cost between $\$ 8 \mathrm{M}$ and $\$ 10 \mathrm{M}$ and to have a 22-year contract term. The project is expected to begin construction in FY 2013.

Monthly tracking of project milestones is provided to the DOE Sustainability Performance Office (SPO) for these three projects as required by the president's $\$ 2 \mathrm{~B}$ performance contracting initiative.

\subsection{Sustainability related investments as required by Circular A-11}

INL has identified 31 internal invest opportunities as reported in the Office of Management and Budget Circular A-11 - Section 25 budget table. The Investment Type breakdown is as follows: 11 projects are Embedded/Leveraged Investments; 14 are Incremental Investments; and six are Alternative Investments. The bulk of the investments are intended to support energy management, water management, and design and construction, but capital equipment and renewable energy are also included. Annually, INL identifies projects and funding necessary to meet the requirements of the DOE Orders. 
The 31 opportunities include control system upgrades, water fixture replacements, efficient motors, electric and water meter installation, outdated mechanical equipment replacement, renewable energy installation, and applying R\&D projects as a proof-of-concept. This list is refined annually based on emerging data analysis and program direction. INL consults with energy, transportation, and environmental coordinators and the SPO as project proposals are revised, ensuring up-to-date direction is incorporated into the decision making process.

\subsection{Integration of Long-Term Sustainability Goals into the Budget Process}

As a government entity, the INL Site is limited in funding acquisition pathways. There is no standard formula for funding sustainability initiatives. However, realistic funding strategies reflect four main sources:

- ESPC and UESCs

- Utility incentive programs

- Direct and indirect funding and reinvesting cost savings from sustainable actions

- Special funding requests (third party, DOE base funding, line item).

A practical hybrid approach is achievable where all stakeholders participate with funding. Each of the four sources has merits and drawbacks. For example, ESPC projects are comprehensive but time consuming to develop. Typically, an ESPC project can take over 12 months for project development followed by 18 months or more for design and construction.

The base Sustainable INL Program is funded with indirect dollars. The program is able to use utility incentives to further fund facility upgrades. Strategic investment dollars are prioritized at a senior leadership level and balanced against Laboratory needs.

The challenge of implementing sustainability is to minimize the impact to operations while increasing the health and viability of the Laboratory. INL is integrating sustainability performance improvements in the areas that matter most to its stakeholders, including minimizing the environmental footprint, taking a progressive approach to mitigating climate change, and championing energy conservation.

\subsection{Reinvestment Program}

The INL Site has three options available for reinvestment of energy and water savings:

- Utility Incentives. Project rebate incentives are available from Idaho Power, Idaho Falls Power, and the Bonneville Power Administration. These incentive programs are routinely used to obtain incentive payments for both internally funding projects and alternatively funded projects. The incentive payments are used to fund additional project opportunities or to buy down the cost of ESPC projects, allowing for additional ESPC ECM implementation.

- ESPC Excess Savings Reinvestment. ESPC projects typically guarantee energy savings less than the expected calculated savings. These excess savings should be identified for reinvestment into additional energy and water saving projects.

- Energy Savings from Internally Funded Projects. All internally funded projects intended to reduce energy consumption provide reinvestment opportunities for realized savings. In FY 2013, savings from the FY 2012 SIF projects will be tracked and a savings reinvestment plan piloted in FY 2014

As meters are installed on the buildings expected to meet the Guiding Principles and on buildings upgraded by ESPC projects, the energy consumption data will be tracked and realized savings will be identified for reinvestment opportunities. This data will be used to develop a draft formal reinvestment program for INL in FY 2013. 


\section{CLIMATE CHANGE ADAPTATION \\ 10.1 Climate Change Adaptation}

The Intergovernmental Panel on Climate Change defines climate adaptation as, "adjustment in natural or human systems in response to actual or expected climatic stimuli or their effects, which moderates harm or exploits beneficial opportunities." The White House Council on Environmental Quality's Interagency Climate Change Adaptation Task Force has established a framework for conducting climate change adaptation planning, and DOE Secretary Chu adopted this framework in his Climate Adaptation Policy Statement of June 2, 2011. According to this document, the federal government's core role should be to:

- Promote and implement best practices for adaptation

- Build greater public awareness and understanding of the importance of adaptation

- Maintain dialogue and partnerships with stakeholders and decision makers

- Enhance services that enable informed decisions based on the best available science

- Work with the international community to improve knowledge sharing.

This report also emphasizes that the federal government must exercise a leadership role to address climate impacts on federal infrastructure interests and on natural, cultural, and historic resources that it has statutory responsibilities to protect; and provides eight Guiding Principles for climate adaptation. These are (i) adopt integrated approaches, (ii) prioritize the most vulnerable, (iii) use the best available science, (iv) build strong partnerships, (v) apply risk management methods and tools, (vi) apply ecosystem based approaches, (viii) maximize mutual benefits, and (viii) continuously evaluate performance.

Secretary Chu's Policy Statement of June 2, 2011 also established a DOE Climate Change Adaptation Planning Working Group, who would draft a climate adaptation plan and integrate it into the SSPP. Secretary Chu's policy statement also notes that climate change adaptation efforts have the potential to provide synergy with DOE's clean energy mission, and states that DOE will explore these opportunities while planning for climate adaptation. The 2012 SSPP established three priority actions for Climate Change Adaptation for FY 2012. In brief, these actions would:

- Outline a strategy to develop realistic climate scenarios, using the best available science

- Gain a better understanding of DOE programmatic implications and opportunities

- Use DOE's existing emergency management, hazard assessment, risk management, and frameworks to evaluate climate change impacts at DOE sites.

The results from this work was summarized in DOE's high-level analysis of vulnerability to climate change, and incorporated into the guidance the FY 2013 Site Sustainability Plans. The following section describes how INL will meet these objectives.

\subsection{Objectives}

INL Site sustainability accomplishments will help DOE meet the following objectives for climate change adaptation, as listed in the FY 2013 SSP Guidance document:

- Goal 1: Improve Understanding of Climate Change Effects and Impacts

- Objective 1.1: Work with other agencies to improve INL's understanding of climate change

- Objective 1.2: Work with other federal agencies and local jurisdictions (as appropriate) to develop regional partnerships for climate change information sharing and collaboration 
- Goal 2: Improve Understanding of Climate Change Vulnerabilities and Risk

- Objective 2.2: Conduct detailed risk or vulnerability assessments, as appropriate, for specific DOE programs or facilities

- Goal 4: Improve the Climate Resiliency of all DOE Sites

- Objective 4.1: Update all appropriate DOE site plans to address climate change resiliency

- Objective 4.2: Identify or establish and participate in regional climate change adaptation partnerships, as appropriate, for all DOE facilities.

Note: Objectives 2.1, 3.1, and 3.2 in the DOE Climate Change Adaptation Plan were excluded from this section as they are not applicable to individual DOE sites.

\subsection{Current Understanding of Potential Climate Change Effects and Impacts}

The United States Global Change Research Program (USGCRP) has assessed climate impacts within nine major U.S. regions. INL is located in the high desert of southeastern Idaho, which is situated within USCGRP's Northwest Region (Figure 1). However, INL's local geography and ecology is more analogous to the Great Basin landscape (Figure 2, light red) than the wetter landscape of the Great Northern landscape that largely defines the USCGRP's Northwest region (Figure 2, dark green). This combination of physical geography and landscape form suggest that INL's site combines aspects of both the Northwest and Southwest regions, as defined by USGCRP. The Jim Bridger coal plant in Wyoming provides much of INL's electricity, and thus climactic trends in the Great Plains climate region could impact INL's electricity services. INL's location at the confluence of three major climate regions requires that impacts on each region be considered. 


\subsubsection{Climate Impacts for the Northwest Region}

The USGCRP reports that annual average temperature over the Northwest region rose about $1.5^{\circ} \mathrm{F}$ over the past century, with some areas experiencing increases up to $4^{\circ} \mathrm{F}$. The region's average temperature is projected to rise another 3 to $10^{\circ} \mathrm{F}$ between now and 2100 (USGCRP, 2009). Rising temperature will impact the region in a number of important ways. Key impacts will include:

- Increased summer temperatures, leading to greater heat stress and higher demand for energy to cool buildings.

- Declining spring snowpack and more

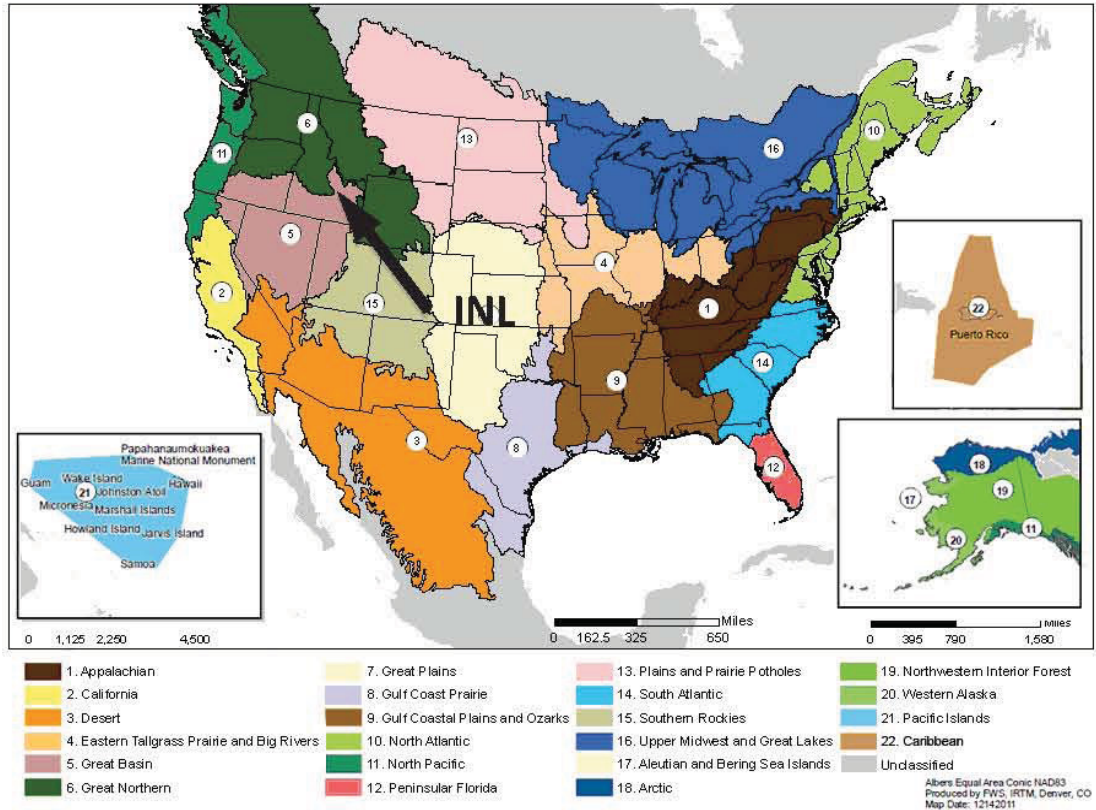

Figure 2. Major landscapes of the United States, as described by the U.S. Geologic Survey (USGS). prevalent spring rains, leading to higher spring run-off and lower summer stream flows and increasing strain on water resources.

- Higher summer water temperature, combined with lower stream flows, would reduce the efficiency and availability of cooling water for power production. This could reduce electricity availability during a period of increased demand for summer cooling.

- Increased incidence and severity of wildfire, impacting human health and safety, restricting site operations, and threatening electricity transmission infrastructure.

- Increased incidence of pestilence and disease, impacting human health and safety, and potentially altering ecosystem function. 


\subsubsection{Climate Impacts for the Southwest Region Applicable to INL}

The USGCRP reports that annual average temperature over the Southwest region rose about $1.5^{\circ} \mathrm{F}$ over the past century, roughly comparable to the Northwest region. Projections of future temperature increase are also roughly comparable with those of the Northwest region. The Southwest region is anticipated to experience severe water shortages, due to large reductions in spring precipitation. INL is located in water basins fed by the Northwest water system, but is immediately adjacent to the Southwest region and has a similar arid landscape.

Ecosystem, fire, and landscape impacts may be more akin to the Southwest region than the Northwest.

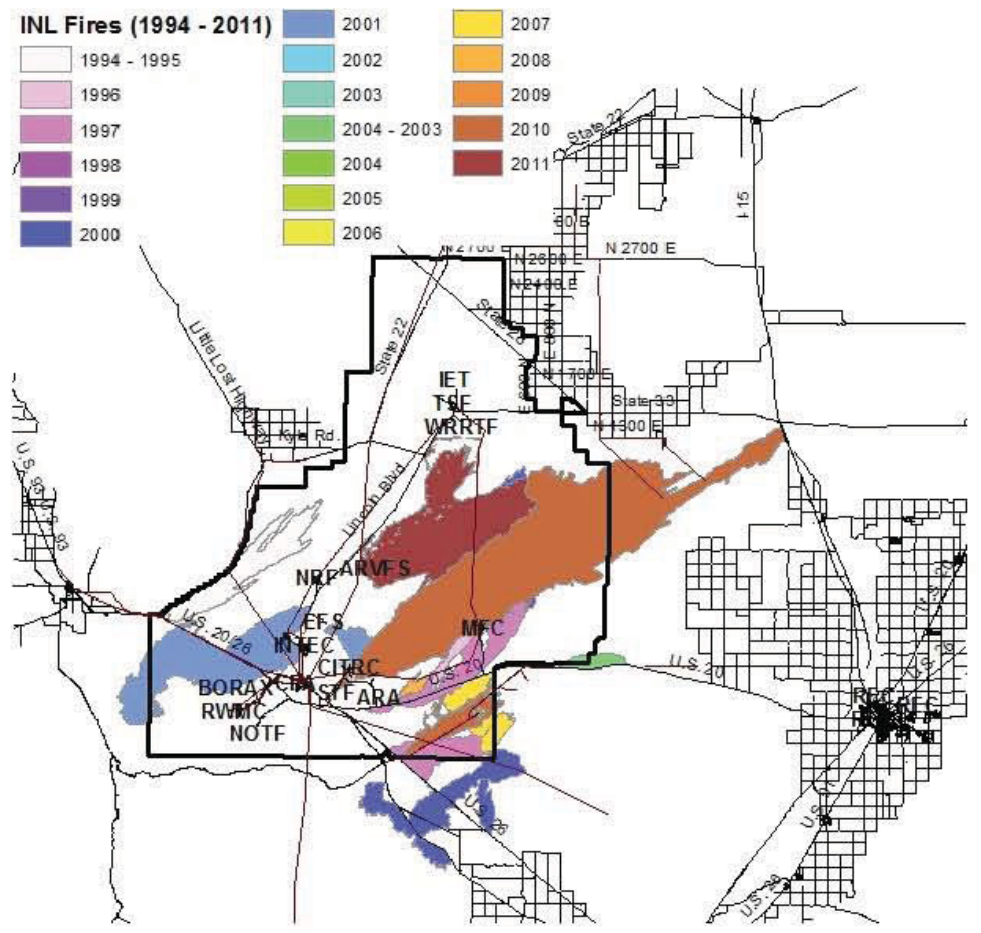

Figure 3. History of wildfire at INL since 1994.

USGCRP predicts that a combination of increasing temperature, drought, invasive species, and more frequent and severe wildfires will accelerate the transformation of the landscape in the Southwest region. Such change will threaten biological diversity, and could lead to large-scale transformation of the animal and plant species residing on INL property. This would alter the environmental basis for INL planning and operations, and may introduce new environmental threats. For example, USGS has projected that climate change in the Southwest would reduce perennial vegetation cover and result in increased dust storm activity in the future (Munson et. al., PNAS 2011). If the landscape of INL transforms toward one that is more reflective of north/central Nevada and Utah, then dust storms could become more frequent and more severe. With regard to wildfires, historical data show that wildfires regularly threaten INL infrastructure and that some of INL's largest fires have occurred in recent years (Figure 3). Recent studies conducted on the INL Site have helped develop new approaches for quantifying the extent of wildfire, dust transport, and landscape change; and have identified potential feedback cycles between these processes. There may be an opportunity to build upon the work to establish an interagency collaboration to help develop a better understanding of the feedbacks between climate change, wildfire, and landscape transformation.

\subsubsection{Climate Impacts for the Great Plains Region Applicable to INL}

USGCRP reports that, over the past century, temperature change in the Great Plains region has been roughly equivalent to that of the Northwest and Southwest regions. Projections of future temperature increase are also roughly comparable with those of the Northwest region. The region is expected to experience increases in the frequency and severity of drought, exacerbating strain on the region's water resources. Lack of water resources could reduce the generating capacity of coal-fired power plants in Wyoming during summer months, thereby reducing the amount of electricity available for INL use. Climate change is also expected to alter the landscape and ecosystem structure in key habitats, which 
could lead to increased restrictions on air emissions, water use, and land use. These factors, combined with ongoing shifts in the region's population, could place greater strain on the region's energy grid and further reduce the amount of electricity available for export.

\subsection{Actions to Fulfill DOE Climate Adaptation Objectives}

INL controls access to a large swath of land that is located at the intersection of three USGCRP climate regions, and provides ready access to both pristine and developed land that is fed by a combination of managed water systems (Snake River) and unmanaged water systems (Salmon River). INL is also the only U.S. National Laboratory located in the Great Basin landscape, which is an environmentally sensitive area that has extensive renewable generation capacity. Thus, INL is well suited to host climate change adaptation research and demonstration activities that (a) help INL gain a better understanding of how climate change will impact human and environmental systems in the intermountain west, (b) test approaches to mitigating future impacts, and (c) provide leadership that will help the region and nation respond to this challenge. A strategy for achieving these goals is outlined in the following sections.

\subsubsection{Goal 1: Improving our Understanding of Climate Impacts in INL's Region}

INL is currently partnering in a number of regional efforts to improve our understanding of climate impacts on the region. Notable examples include:

- Providing a field study site for understanding relationships between fire, dust transport, and ecosystem change in the Great Basin landscape.

- Hosting the Mountain West Water Institute, which is a federal/state collaboration that provides the science, predictive tools, and technologies needed to help the region's water stewards and users rapidly and effectively assess, monitor, and proactively adapt to changes in resource conditions.

- Hosting a mirror site for the Northwest Knowledge Network (NKN), which is a data management system that provides storage, retrieval, and protection services across the life cycle of data. NKN serves researchers, educators, and the public specializing in cross-disciplinary data and its application to issues of note in the state and northwest region. NKN currently has 20 federal, state, and university partners, and provides data services for regional initiatives that include the Northwest Climate Science Center and the Fire Research and Management Exchange Systems (FRAMES).

- Actively collaborating with university peers supported by the Nation Science Foundation (NSF)funded Idaho Experimental Program to Stimulate Competitive Research (EPSCoR) project, which is developing regional $R \& D$ capacity to improve our understanding of how climate change will impact water resources.

INL will fulfill the objectives of Goal 1 (i.e., Improve our Understanding of Climate Change) by expanding current involvement with these regional initiatives. INL actions to advance Goal 1 will focus on two outcomes:

1. Develop and implement R\&D collaborations with regional universities and governmental agencies to understand how climate change impacts on regional fire risk, ecosystem function, and water resources will impact the delivery of energy and water services to both INL facilities and the regional community at-large.

2. Develop a collaborative R\&D plan for how INL could function as a field research site to improve the laboratory's understanding of (a) how climate change will impact the ability of the Great Basin landscape to sustainably support regional economic and energy development, and (b) develop and test new monitoring and resource management technologies and strategies that could support climate change adaptive management. 
The first step towards achieving these objectives would be for INL to host a regional scientific forum to define research needs and develop a research plan for how to meet these goals. This forum could be conducted as either a regional meeting at INL, hosted by MWWI; or by INL researchers hosting a special forum at a regional climate science meeting. The product of this effort would be a Strategic Research Plan that would be delivered to the leadership of all participating institutions and agencies (including DOESPO), and made available to the public. INL's ability to pursue this objective in FY 2013 is dependent on identifying a mechanism for funding the required travel and staff costs.

\subsubsection{Goal 2: Assessing Climate Change Vulnerability and Risk at INL}

Assessing climate vulnerability requires a strong understanding of the climate risks, their relative severity, and what time scale on which they are likely to operate. Thus, climate change vulnerability assessments will be updated regularly as the science advances and climate change impacts become more noticeable. Detailed INL-site vulnerability assessments will be made every 4 years, in the year following the issuance of the quadrennial USGCRP National Climate Assessment. In the interim years, the site vulnerability assessment will be updated to reflect new knowledge; and integrated into the INL SSP.

In FY 2013, INL will support Objective 2.2 by using the 2009 National Climate Assessment as the basis for conducting our first Climate Change Vulnerability Assessment. To achieve this outcome, INL will conduct two activities as funding is available:

1. Using the 2009 National Climate Assessment and the DOE High Level Analysis of Vulnerability to Climate Change as a basis, INL will develop a report that summarizes anticipated climate impacts to the Site, workforce, and community in the coming decade. This report will be written and reviewed in collaboration with regional experts.

2. Once this report is prepared, INL will present its results to site operations officials and conduct a vulnerability assessment. Options for mitigating vulnerabilities will also be discussed and assessed. The results from this risk and vulnerability assessment will then be published in an INL technical report, which will also be reviewed by regional experts.

These objectives can be met with current knowledge, gained through literature review and consultations with subject matter experts at regional universities and partner agencies. This work can proceed independently of efforts to support Goal 1 . However, work advancing towards this goal will proceed synergistically with progress towards Goal 1 to the greatest extent practicable.

\subsubsection{Goal 4: Improving Climate Resiliency at INL}

Efforts to advance Goal 4 are limited by the lack of a site-specific climate vulnerability assessment. Site plans cannot be updated until a vulnerability assessment has been completed. Consequently, progress toward Objective 4.1 will proceed concomitantly with progress toward Objective 2.2. Once a vulnerability assessment has been completed and an action plan established, INL will track progress towards climate resiliency goals. INL will support progress toward Objective 4.2 through its partnering efforts conducted in support of Goal 1.

For the purposes of the INL SSP, the brief review of the 2009 USGCRP National Climate Assessment reveals five key areas of potential vulnerability. These are:

1. Increased potential for wildfire and associated risk to worker safety, INL operations, and INL infrastructure

2. Increased threats to worker safety through heat stress, dehydration, and exposure to disease and pests

3. Increased uncertainty in infrastructure planning and permitting due to the potential for long-term landscape change

4. Increased uncertainty regarding water availability to support INL Site operations 
5. Increased risk of power disruptions during summer months, when water shortages could lead decreased production from the region's electricity facilities.

These potential vulnerabilities can be mitigated through existing INL safety, operations, and infrastructure planning processes. These five areas of potential vulnerability will provide the initial basis for FY 2013 efforts to (a) develop a detailed climate vulnerability assessment, and (b) enhance and/or establish regional partnerships that work to improve our understanding of climate change impacts and the viability of alternative technology and adaptive management responses.

\subsection{Synergies with Climate Mitigation Efforts and Laboratory Mission}

INL's mission is to provide science and technology solutions that help ensure the nation's energy security with safe, competitive, and sustainable energy systems and unique national and homeland security capabilities. INL achieves this mission by functioning as the pre-eminent nuclear energy laboratory with synergistic multi-program capabilities and partnerships. There are many synergies between INL's mission and the climate adaptation imperative, including:

- An improved understanding of how climate change will impact water availability, fire risk, and ecosystem function and how these factors could combine to impact nuclear facility design, siting, and operations.

- As above, but for renewable energy production facilities; with a focus on landscapes in the Great Basin and surrounding regions.

- As above, but with a focus on national and homeland security issues.

- Development and demonstration of environmental monitoring technologies that can help facilitate clean energy development by improving capabilities for real-time response of energy systems to environmental stimuli.

- Efforts to reduce the carbon footprint of INL operations and progress toward zero-carbon facilities provide opportunities to conduct demonstration projects that can show local and regional stakeholders how transitioning to clean, sustainable energy generation also improves climate resiliency.

- INL's network of regional partnerships provides a basis for educating regional stakeholders on their sustainable energy options, and developing mobile units that can travel throughout the region to demonstrate effective climate adaptation strategies.

- AMWTP has observed that with milder winters, potentially associated with the effects of climate change, AMWTP maintenance has consumed lower volumes of diesel and gasoline onsite. This reduction is credited to fuel that is normally necessary for powering heavy equipment associated with snow removal during harsh Idaho winters.

- The potential for warmer winters at INL suggests that many of the operations occurring in traditionally unconditioned spaces (the Transuranic Storage Area - Retrieval Enclosure [TSA-RE] and the AMWTP Type II modules) will result in reduced consumption of fossil fuels used for more inefficient area heating. This reduction may reduce the contribution of emissions at AMWTP toward the potential for anthropogenic climate change. 
(This Page Intentionally Left Blank) 
Appendix A

Glossary 
(This Page Intentionally Left Blank) 


\section{Appendix A}

\section{Glossary}

Alternative Fuel. A vehicle or equipment fuel that is either not petroleum based, or significantly reduces the petroleum content of the fuel. Biodiesel blends such as B20 (20\% biodiesel) and Ethanol blends such as E- 85 ( $85 \%$ Ethanol) are the more common alternative fuels. Compressed natural gas (CNG) and liquefied natural gas (LNG) are also recognized alternative fuels that are not a blended fuel.

Alternative Fuel Vehicle ( $A F V$ ). Vehicles specially designed to run on an alternative fuel. They can be dedicated to a single alternative fuel such as LNG, or they can be dual fuel capable of operating on both alternative such as CNG or E-85 and gasoline. Diesel engine vehicles that can simply be operated on a biodiesel blend are usually not considered AFVs.

Commissioning. A process of ensuring that all building systems are installed and perform interactively according to the design intent, the systems are efficient and cost effective and meet the owner's operational needs, the installation is adequately documented, and the operators are adequately trained.

Commissioning Authority. The individual hired by, or responsible to, the building owner and is tasked with implementing the commissioning process for a new or existing building. The Commissioning Authority is typically responsible for all aspects of the commissioning process, leads and trains the commissioning team, and witnesses or verifies all system checks or inspections throughout the process. The Commissioning Authority has final jurisdiction for the entire commissioning process.

Continuous Commissioning. Continuous commissioning involves ongoing monitoring and testing of systems as part of a regular maintenance plan to ensure optimum performance and enhanced equipment longevity. Continuous commissioning can be at a system or a building level depending upon the requirements of the stakeholders.

Energy Efficiency. The ability of a building to minimize the amount of energy used for employee safety, health, and comfort. Energy efficiency also applies to the processes that are performed inside the building, which are not necessarily part of the physical structure. Energy efficiency improvements should always be measured by life-cycle cost effectiveness, and not by first cost or simple payback.

ESPC. Energy Savings Performance Contracts (ESPC) are projects that are developed, engineered, performed, and funded by an outside contractor called an Energy Services Contractor (ESCo). ESPCs are paid for through the energy savings derived from the project and are intended to be a no-cost turn-key process or project. The annual payments are made to the ESCo with funds that would have been distributed to the utility. ESPCs are especially useful when capital funding is not readily available. DOE sites can take advantage of the ESPC program, which provides pre-evaluated ESCos familiar with federal processes.

HVAC. Heating, ventilating, and/or air conditioning (cooling) systems in a building. HVAC systems include all components, controls, and distribution systems needed to deliver conditioned air to the desired point of use.

Indoor Environment. A building's indoor environment includes many factors including the quality of the air in and supplied to the building, temperature levels, and consistency throughout the building, amount of pollutants in the workspace, lighting levels, and quality, levels of unwanted sound, and amount of day lighting.

INL Site. All contractors and activities at the INL Site under the control of the DOE-ID Operations Office, but excludes the Naval Reactors Facility (NRF). 
LEED $^{\mathrm{TM}}$ Rating System. Leadership in Energy and Environmental Design (LEED ${ }^{\mathrm{TM}}$ ) is a tool for green building design to help design teams and owners determine green project goals, identify green design strategies, measure and monitor progress, and document success. The LEED ${ }^{\mathrm{TM}}$ Rating System was developed and is administered by the U.S. Green Building Council (USGBC), which is a national nonprofit organization that includes representation from all aspects of the building industry. The LEED TM Rating System is a point system of five technical categories and four levels of certification: LEED ${ }^{\mathrm{TM}}$ Certified, Silver, Gold, and Platinum.

Low-Cost. Low Cost modifications or repairs may be performed during the commissioning process, but are typically implemented shortly after. Low-cost opportunities typically cost less than $\$ 500$ and can be accomplished in bundled groups.

No-Cost. Adjustments or modifications that can be made during the commissioning implementation phase by in-house crafts. These on-the-spot modifications are essentially no cost other than the time for the craft person to be available. No-cost adjustments should be maximized during the implementation phase.

Re-commissioning. Commissioning that is performed several years after a building, which was previously commissioned, has been in operation to ensure that the building and systems are meeting the original design requirements. Re-commissioning is typically used to identify and correct malfunctions in a building that occur as the building ages and to ensure continued indoor air quality, employee productivity, and energy efficiency. Re-commissioning can also be used to address changes in ownership, building use patterns, and operation and maintenance practices. A building's use and mission often change during the building's life and these changes necessitate the need for re-commissioning to ensure that the building is capable of efficiently meeting its new and/or evolving mission.

Retro-commissioning. Applying the commissioning process to a building that has never been commissioned. Retro-commissioning is sometimes referred to as "Existing Building Commissioning" and is used to compare the building's original design parameters and operational criteria with current design and operational requirements. Retro-commissioning determines if the building is capable of meeting its current mission needs and identifies modifications required to meet those needs. Retro-commissioning then identifies upgrades to the building that will enhance its energy efficiency, tenant comfort and productivity, and indoor air quality. Retro-commissioning as a best practice means using a whole building approach to ensure that the building is operating within well-defined criteria established by the building stakeholders.

Sustainability. The ability of a society to operate indefinitely into the future without depleting its resources. Sustainability includes concepts of green building design and construction, reuse and recycling of materials, reduced use of material and energy resources for building construction and operation, water conservation, and responsible stewardship of the environment adjacent to the building. 
Appendix B

\section{Excluded Buildings Self-Certification}


(This Page Intentionally Left Blank) 


\section{DOE BUILDING EXCLUSION \\ SELF-CERTIFICATION FORM}

FY 2012

FROM: DOE Idaho Operations Office, Idaho National Laboratory Site

Lead Program Office is the Office of Nuclear Energy

TO: Sustainability Performance Office

DATE: November 19, 2012

\section{SUBJECT: SELF-CERTIFICATION FORM FOR THE ENERGY INTENSITY GOAL OF EISA 2007}

Each building or group of buildings excluded under the criteria for a Part $\mathrm{G}$ or Part $\mathrm{H}$ exclusion is/are metered for energy consumption and their consumption is reported annually.

If any building has been excluded under the criteria for Part $\mathrm{H}$ for impracticability then all practicable energy and water conservation measures with a payback of less than 10 years have been installed. A justification statement that explains why process-dedicated energy in the facility may impact the ability to meet the goal has been provided in the FIMS Report 063.

I certify that the buildings listed on the Excluded Buildings List produced by FIMS as Report 063 dated 19 November 2012, for the Idaho National Laboratory Site meet the exclusion criteria in Guidelines Establishing Criteria for Excluding Buildings published by FEMP on January 27, 2006.

Teresa Perkins

DOE Site Office Official - printed name

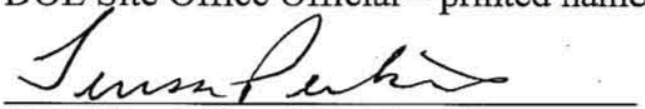

DOE Site Office Official - Signature

November 19, 2012

Date

Contact Information:

Teresa Perkins, Director

Environment and Sustainability Division DOE-ID

Phone: (208)526-1483

eMail: perkintl@,id.doe.gov

Or: Ernest Fossum,

INL Energy Manager

(208)526-2513

Ernest.Fossum@,inl.gov 


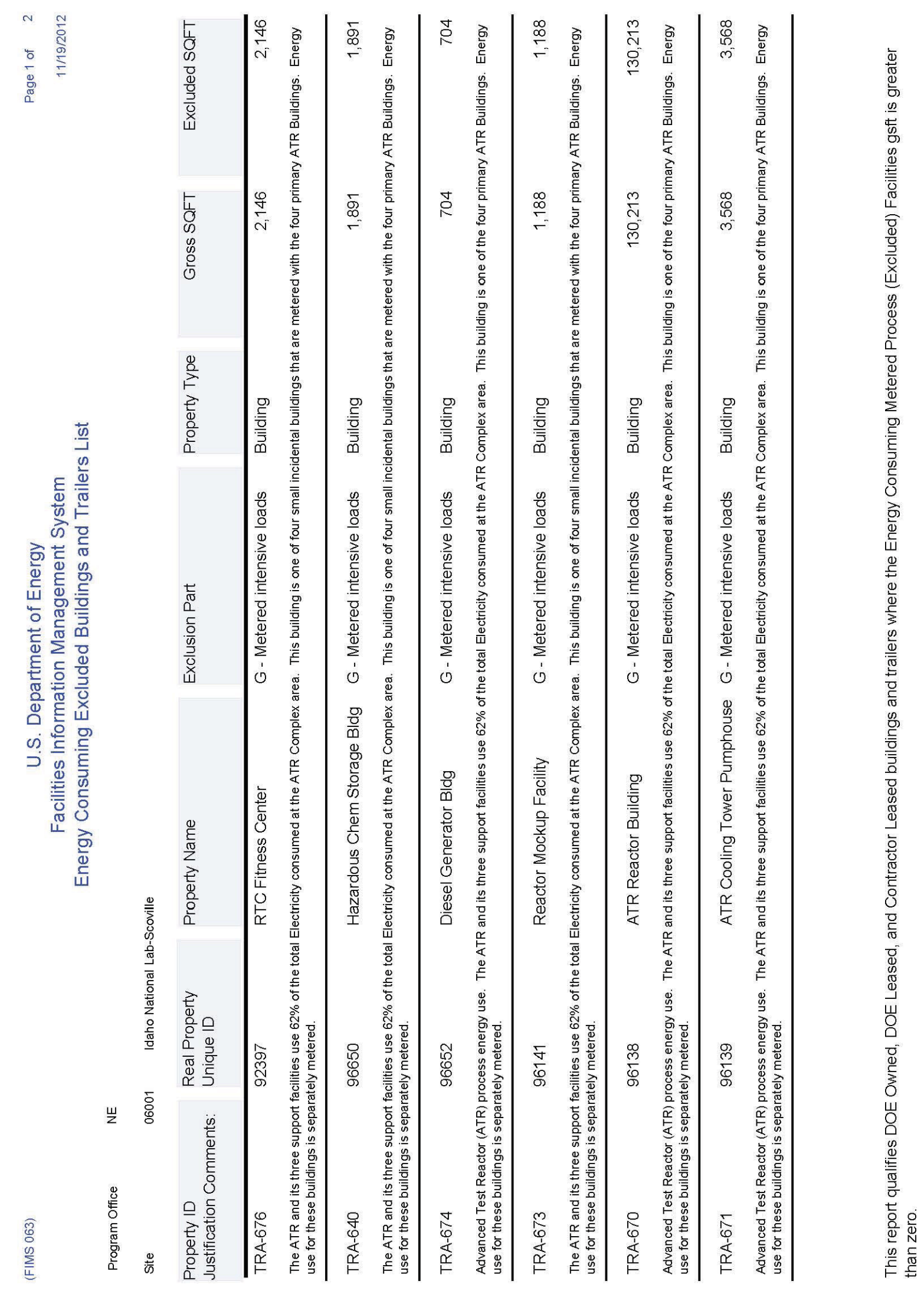



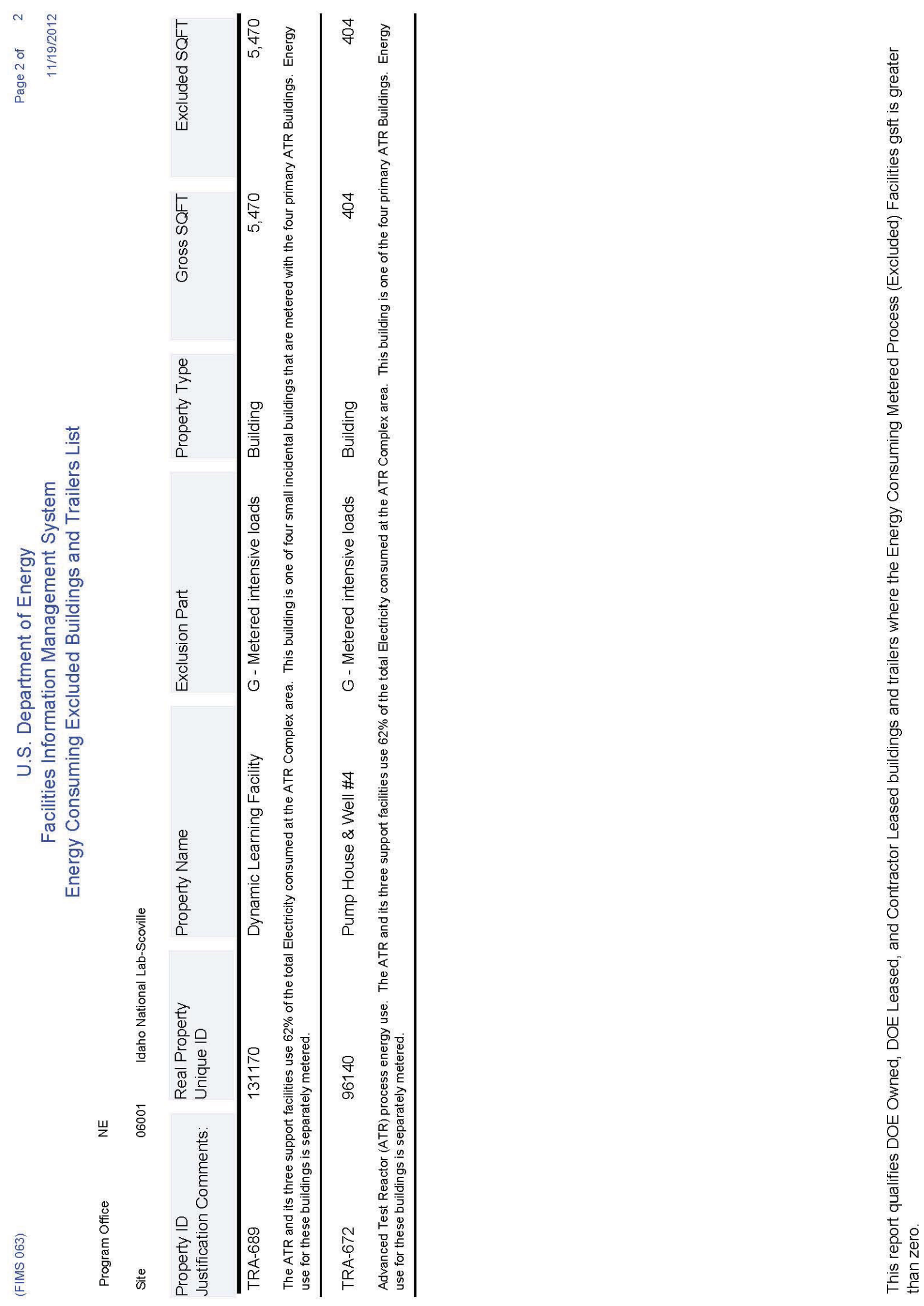
(This Page Intentionally Left Blank) 


\section{Appendix C}

Consolidated Energy Data Report (CEDR) 
(This Page Intentionally Left Blank) 


\section{CEDR Content}

The Consolidated Energy Data Report (CEDR) consists of 23 worksheets that should be completed by each site, as applicable, and included as part each site's SSP in a MS Excel electronic format. The CEDR is due to the SPO no later than December 7 th.

\begin{tabular}{|c|c|c|c|}
\hline \multicolumn{2}{|c|}{ Worksheet } & \multirow{2}{*}{$\begin{array}{l}\text { Overview } \\
\text { Stand-alone overview of the CEDR tabs. }\end{array}$} & \multirow{2}{*}{ Action } \\
\hline 1.1 & Content & & \\
\hline 1.2 & Performance Summary & Summary table of goals performance. & None. \\
\hline 1.3 & $\begin{array}{l}\text { Factors and Drop-down } \\
\text { Keys }\end{array}$ & Reference tab containing all factors and drop-down menus information for all tabs. & None. \\
\hline 2.1 & Funds, Meters, Training & Collects information on energy and water spending, and metering status. & If applicable, complete cells with blue text. \\
\hline 3.1 & Energy \& Water & $\begin{array}{l}\text { Collects quarterly consumption and associated cost information for facilities, non- } \\
\text { fleet vehicles and equipment, and fully serviced leases (new, voluntary in FY } \\
\text { 2012) for each fiscal year since FY 2003. Do not report on-site generated and } \\
\text { purchased renewable energy or on-site generated non-renewable energy in this tab. }\end{array}$ & $\begin{array}{l}\text { Enter FY } 2012 \text { consumption and cost data and review } \\
\text { historical information for accuracy. }\end{array}$ \\
\hline $3.2 \mathrm{a}$ & $\begin{array}{l}\text { Operating On-Site } \\
\text { Renewables }\end{array}$ & $\begin{array}{l}\text { Houses the list of active renewable energy systems at DOE sites to track progress } \\
\text { towards renewable energy requirements in EPAct } 2005 \text { and DOE O 436.1. Also } \\
\text { used towards developing the site's GHG inventory. }\end{array}$ & Review pre-populated data and update as necessary. \\
\hline $3.2 \mathrm{~b}$ & Purchased Renewables & $\begin{array}{l}\text { Collects renewable energy purchases to track progress towards renewable energy } \\
\text { requirements in EPAct } 2005 \text { and DOE O } 436.1 \text {. Also used towards developing the } \\
\text { site's GHG inventory. }\end{array}$ & $\begin{array}{l}\text { Review pre-populated data and update with FY } 2012 \\
\text { purchased data. }\end{array}$ \\
\hline 3.3 & $\begin{array}{l}\text { Conservation \& RE } \\
\text { Measures }\end{array}$ & $\begin{array}{l}\text { Tracks planned energy and water conservation measures, in addition to future } \\
\text { renewable energy systems. Also used to project future energy/water consumption } \\
\text { along with performance towards goals. }\end{array}$ & Review pre-populated data and update as necessary. \\
\hline 3.4 & Bldg Inventory Changes & $\begin{array}{l}\text { Tracks demolition and new construction projects along with construction } \\
\text { requirements for meeting HPSB, EPAct } 200530 \text { percent better than ASHRAE, } \\
\text { and stormwater design. Also used to project future energy/water consumption. }\end{array}$ & Review pre-populated data and update as necessary. \\
\hline 4.1 & $\begin{array}{l}\text { Source Energy Savings } \\
\text { Credit }\end{array}$ & $\begin{array}{l}\text { Part of the Annual Energy Report to adjust site energy use accounting from } \\
\text { projects - especially combined heat and power - that would change the } \\
\text { accounting of site vs. source energy. }\end{array}$ & Complete worksheet, if applicable. \\
\hline 5.1 & Data Centers & Inventory of DOE data centers along with basic energy management metrics. & Complete worksheet, if not using DOEGRIT. \\
\hline 6.1 & Mixed Refrigerants & $\begin{array}{l}\text { Collects and calculates fugitive emission data for refrigerants and fluorinated } \\
\text { gases. }\end{array}$ & $\begin{array}{l}\text { Review pre-populated data and update with FY } 2012 \\
\text { emissions. }\end{array}$ \\
\hline 6.2 & Fugitive F-gases & $\begin{array}{l}\text { Collects and calculates fugitive emission data for fluorinated gases and other } \\
\text { fugitive emissions. }\end{array}$ & $\begin{array}{l}\text { Review pre-populated data and update with FY } 2012 \\
\text { emissions. }\end{array}$ \\
\hline 6.3 & Industrial Process & Collects and calculates GHG emission data for industrial process by process. & $\begin{array}{l}\text { Review pre-populated data and update with FY } 2012 \\
\text { emissions. }\end{array}$ \\
\hline $7.1 \mathrm{a}$ & On-Site Wastewater & Collects and calculates fugitive emissions data for on-site wastewater treatment. & $\begin{array}{l}\text { Review pre-populated data and update with FY } 2012 \\
\text { emissions. }\end{array}$ \\
\hline $7.1 \mathrm{~b}$ & Contr. Wastewater & $\begin{array}{l}\text { Collects and calculates GHG emissions resulting from contracted off-site } \\
\text { wastewater treatment, excluding electricity. }\end{array}$ & $\begin{array}{l}\text { Review pre-populated data and update with FY } 2012 \\
\text { emissions. }\end{array}$ \\
\hline 8.1 & Air Bus Travel & $\begin{array}{l}\text { Collects and calculates emissions for prime contractor employee business air } \\
\text { travel. }\end{array}$ & $\begin{array}{l}\text { Review pre-populated data and update with FY } 2012 \\
\text { emissions. }\end{array}$ \\
\hline 8.2 & Ground Bus Travel & $\begin{array}{l}\text { Collects and calculates emissions for prime contractor employee business ground } \\
\text { travel. }\end{array}$ & $\begin{array}{l}\text { Review pre-populated data and update with FY } 2012 \\
\text { emissions. }\end{array}$ \\
\hline 8.3 & Commuter Travel & Collects and calculates emissions for prime contractor employee commuting. & $\begin{array}{l}\text { Review pre-populated data and update with FY } 2012 \\
\text { emissions. }\end{array}$ \\
\hline $9.1 \mathrm{a}$ & $\begin{array}{l}\text { On-Site Landfill } \\
\text { (Optional) }\end{array}$ & $\begin{array}{l}\text { Calculates emissions for on-site landfill; data should be consistent with PPTRS } \\
\text { entry. }\end{array}$ & Optional - Based on PPTRS data entry. \\
\hline $9.1 \mathrm{~b}$ & Off-Site MSW (Optional) & $\begin{array}{l}\text { Calculates emissions for contracted/off-site municipal solid waste disposal; } \\
\text { data should be consistent with PPTRS entry. }\end{array}$ & Optional - Based on PPTRS data entry. \\
\hline 10 & Fleet Fuel (Optional) & Calculates emissions for fleet fuel consumption based on FAST data. & Optional - Download and paste FAST data. \\
\hline 11 & Covered Facilities & List of covered facilities with anticipated evaluation dates and type/level. & $\begin{array}{l}\text { Select covered facilities and complete associated data } \\
\text { columns. }\end{array}$ \\
\hline
\end{tabular}




\section{Performance Summary}

The table bel ow summarized performance for several sustainability goals based on information reported in this workbook. Please note, Scope $1 \& 2$ GHG emissions do not include emissions from on-site and contracted landfill as these are to be reported in PPTRS.

\begin{tabular}{|c|c|c|c|c|}
\hline $\begin{array}{c}\text { SSPP } \\
\text { Goal \# }\end{array}$ & DOE Goal & Baseline & Current FY & $\begin{array}{c}\text { Performance } \\
\text { Status }\end{array}$ \\
\hline 1.1 & $\begin{array}{l}28 \% \text { Scope } 1 \& 2 \text { GHG reduction by FY } 2020 \text { from a FY } \\
2008 \text { baseline }\end{array}$ & $141,102.9$ & $112,484.3$ & $-20.3 \%$ \\
\hline 1.2 & $\begin{array}{l}13 \% \text { Scope } 3 \text { GHG reduction by FY } 2020 \text { from a FY } \\
2008 \text { baseline }\end{array}$ & $28,853.7$ & $26,760.9$ & $-7.3 \%$ \\
\hline \multirow[t]{3}{*}{2.1} & $\begin{array}{l}30 \% \text { energy intensity reduction by FY } 2015 \text { from a FY } \\
2003 \text { baseline } \\
\text { (Note: Estimates without REC credit) }\end{array}$ & 183,011 & 157,690 & $-13.8 \%$ \\
\hline & Goal Energy $\left(10^{\wedge} 6 \mathrm{Btu}\right)$ & $1,023,492$ & 856,316 & \\
\hline & Goal Square Footage $(\mathrm{x} 1,000)$ & 5,593 & 5,430 & \\
\hline $2.3 \mathrm{a}$ & $\begin{array}{l}\text { Individual buildings or processes metering for } 90 \% \text { of } \\
\text { electricity (by October 1, 2012) }\end{array}$ & & $49.0 \%$ & $49.0 \%$ \\
\hline $2.3 b$ & $\begin{array}{l}\text { Individual buildings or processes metering for } 90 \% \text { of } \\
\text { natural gas (by October } 1,2015 \text { ) }\end{array}$ & & $100.0 \%$ & $100.0 \%$ \\
\hline $2.3 \mathrm{c}$ & $\begin{array}{l}\text { Individual buildings or processes metering for } 90 \% \text { of } \\
\text { steam (by October } 1,2015 \text { ) }\end{array}$ & & $0.0 \%$ & $0.0 \%$ \\
\hline $2.3 \mathrm{~d}$ & $\begin{array}{l}\text { Individual buil dings or processes metering for } 90 \% \text { of } \\
\text { chilled water (by October } 1,2015 \text { ) }\end{array}$ & & $0.0 \%$ & $0.0 \%$ \\
\hline 2.7 & $\begin{array}{l}7.5 \% \text { of annual el ectricity consumption from renewable } \\
\text { sources by FY } 2013 \text { and thereafter }(5 \% \text { FY } 2010-2012)\end{array}$ & 221,512 & 22,000 & $9.9 \%$ \\
\hline 3.1 & $\begin{array}{l}2 \% \text { annual reduction in fleet petroleum consumption by } \\
\text { FY } 2020 \text { relative to a FY } 2005 \text { baseline } \\
\text { (Note: Estimates without biodiesel credit) }\end{array}$ & 938,197 & 747,777 & $-20.3 \%$ \\
\hline 3.2 & $\begin{array}{l}10 \% \text { annual increase in fleet alternative fuel consumption } \\
\text { by FY } 2015 \text { relative to a FY } 2005 \text { baseline }\end{array}$ & 76,436 & 194,429 & $154.4 \%$ \\
\hline \multirow{3}{*}{4.1} & $\begin{array}{l}26 \% \text { water intensity reduction by FY } 2020 \text { from a FY } \\
2007 \text { baseline }\end{array}$ & 173.9 & 154.0 & $-11.4 \%$ \\
\hline & Potable Water Consumption $\left(10^{\wedge} 6 \mathrm{Gal}\right)$ & 1,051 & 859 & \\
\hline & Total Gross Square Footage $(x 1,000)$ & 6,043 & 5,576 & \\
\hline 4.2 & $\begin{array}{l}20 \% \text { water consumption reduction of industrial, } \\
\text { landscaping, and agricultural ( } \amalg \text { A) water by FY } 2020 \\
\text { from a FY } 2010 \text { baseline }\end{array}$ & 0 & 0 & $0.0 \%$ \\
\hline
\end{tabular}

With New IWith Old E Diff

$\begin{array}{lll}5722.313 & 8198.7 \quad 2476.387\end{array}$ 
Requirement(s): See table

Instructions If applicable, complete cells with blue text and highlight the cell. The information requested is for completing DOE's Annual Energy Report

Source: Site/Lab

All data reviewed, updated, and is correct for FY 2013 CEDR Rep ort - Ernest Fossum 11/26/12

\section{ENERGY EFFICIENCY IMPROVEMENTS AND FUNDING}

\begin{tabular}{|c|c|c|c|c|c|c|}
\hline & \multicolumn{2}{|c|}{ FY 2012} & \multicolumn{2}{|c|}{ Projected FY 2013} & \multicolumn{2}{|c|}{ Projected FY 2014} \\
\hline & & (Thou. S) & & (Thou. \$) & & (Thou.\$) \\
\hline $\begin{array}{l}\text { Direct obligations for facility energy } \\
\text { efficiency improvements, including facilit } \\
\text { surveys/audits }\end{array}$ & & $\$ 830.0$ & & $\$ 1,200.0$ & & $\$ 1,000.0$ \\
\hline $\begin{array}{l}\text { Estimated annual energy savings } \\
\text { anticipated from obligations (Million } \\
\text { BTU) }\end{array}$ & $5,744.2$ & $\$ 71.7$ & $6,500.0$ & $\$ 120.0$ & $6,000.0$ & $\$ 100.0$ \\
\hline $\begin{array}{l}\text { Estim ated annual water savings anticipate } \\
\text { from obligations (Thousands Gal) }\end{array}$ & 347.0 & $\$ 0.9$ & $5,000.0$ & $\$ 13.4$ & 0.0 & $\$ 0.0$ \\
\hline
\end{tabular}

lar A-11 Awarded Energy Savings Performance Contracts (ESPC)

\begin{tabular}{|c|c|c|}
\hline & $\begin{array}{l}\text { Annual savings } \\
\left(10^{\wedge} 6 \mathrm{BTU}\right)\end{array}$ & (Number/Thou. \$) \\
\hline $\begin{array}{l}\text { Number of ESPC Task/Delivery Orders } \\
\text { awarded in fiscal year \& annual energy } \\
\text { (Million BTU) savings }\end{array}$ & 0.0 & 0.0 \\
\hline \multicolumn{2}{|c|}{$\begin{array}{l}\text { Investment value of ESPC Task/D elivery Orders awar ded in } \\
\text { fiscal year }\end{array}$} & $\$ 0.0$ \\
\hline \multicolumn{2}{|c|}{$\begin{array}{l}\text { Amount privately financed under ESPC TaskD Delivery Order } \\
\text { awarded in fiscal year }\end{array}$} & $\$ 0.0$ \\
\hline \multicolumn{2}{|c|}{$\begin{array}{l}\text { Cumulative guaranteed cost savings of ESPCs awarded in } \\
\text { fiscal year relative to the baseline spending }\end{array}$} & $\$ 0.0$ \\
\hline \multicolumn{2}{|c|}{$\begin{array}{l}\text { Total contract award value of ESPCs aw arded in fiscal year } \\
\text { (sum of contractor payments for debt repayment, M\&V, and } \\
\text { other negotiated performance period services) }\end{array}$} & $\$ 0.0$ \\
\hline \multicolumn{2}{|c|}{ Total payments made to all ESPC contractors in fiscal year } & $\$ 2,267.8$ \\
\hline
\end{tabular}

1-3. E.o. 13514/OMB Cir cular A-11 Awarded Utility Energy Ser vices Contracts (UESCs)

\begin{tabular}{|l|r|r|}
\hline & $\begin{array}{c}\text { Annual savings } \\
\left(10^{\wedge} 6 \text { BTU) }\right.\end{array}$ & (Number/Thou. \$) \\
\hline $\begin{array}{l}\text { Number of UESC Task/Delivery Orders } \\
\text { awarded in fiscal year \& annual energy } \\
\text { (Million BTU) savings }\end{array}$ & 0.0 & \\
\hline $\begin{array}{l}\text { Investm ent value of UESC Task/Delivery Orders aw arded in } \\
\text { fiscal year }\end{array}$ & \\
\hline $\begin{array}{l}\text { Amount privately financed under UESC Task/Delivery } \\
\text { Orders awarded in fiscal year }\end{array}$ & $\$ 0.0$ \\
\hline $\begin{array}{l}\text { Cumulative cost savings of UESCs awarded in fiscal year } \\
\text { relative to the baseline spending }\end{array}$ & $\$ 0.0$ \\
\hline $\begin{array}{l}\text { Total contract award value of UESCs awarded in fiscal year } \\
\text { (sum of payments for debt repayment and other negoti ated } \\
\text { perform ance period services) }\end{array}$ & $\$ 0.0$ \\
\hline Total payments made to all UESC contractors in fiscal year & $\$ 0.0$ \\
\hline
\end{tabular}

1-4. EPAct 1992 Training

\begin{tabular}{|l|r|r|}
\hline & (Number) & \multicolumn{1}{|c|}{ (Thou. \$) } \\
\hline Number of personnel trained in & & $\$ 2$ \\
FY 2012/Expenditure & & $\$ 47.6$ \\
\hline
\end{tabular}


Requirement(s): See tables

Instructions If applicable, complete cells with blue text and highlight the cell. The inform ation requested is for completing DOE's Annual Energy Report.

Source: Site/Lab All data reviewed, updated, and is correct for FY 2013 CEDR Rep ort - Ernest Fossum 11/26/12

1-5a. EPAct 2005 Metering Of Electricity Use

(Note: If a buil ding has an advanced and a standard meter, only account for the advanced meter. If a buil ding has multiple meters, ensure the utility metered is accounted/reported only once)

\begin{tabular}{|c|c|c|c|c|c|c|c|c|c|c|}
\hline \multirow[b]{2}{*}{ Fiscal Year } & \multirow{2}{*}{$\begin{array}{c}\text { \# of } \\
\text { "Appropriate } \\
\text { "Buildings } \\
\text { Per EPAct } \\
2005\end{array}$} & \multicolumn{3}{|c|}{ Standard Meters } & \multicolumn{3}{|c|}{ Advanced Meters } & \multicolumn{2}{|c|}{ Total } & \multirow[b]{2}{*}{$\begin{array}{c}\text { Total \% of } \\
\text { Electricity } \\
\text { Metered }\end{array}$} \\
\hline & & $\begin{array}{c}\text { \# of Buildings } \\
\text { with Standard } \\
\text { Meters }\end{array}$ & $\begin{array}{c}\begin{array}{c}\text { Estimated Am ount } \\
\text { of Purchased } \\
\text { Electricity Meter ed } \\
\text { (kWh/Yr) }\end{array} \\
\end{array}$ & $\begin{array}{c}\begin{array}{c}\text { Estimated Amount } \\
\text { of On-Site Generate } \\
\text { Electricity Metered } \\
(\mathrm{kWh} / \mathrm{Yr})\end{array} \\
\end{array}$ & \begin{tabular}{|c|} 
\# of Buildings \\
with \\
Advanced \\
Meters
\end{tabular} & \begin{tabular}{|c|}
$\begin{array}{c}\text { Estimated Amount } \\
\text { of Purchased } \\
\text { Electricity Metered } \\
(\mathrm{kWh} / \mathrm{Yr})\end{array}$ \\
\end{tabular} & $\begin{array}{c}\text { Estimated Amount } \\
\text { of On-Site Generate } \\
\text { Electricity Metered } \\
(\mathrm{kWh} / \mathrm{Yr})\end{array}$ & $\begin{array}{c}\text { \# of Appropriate } \\
\text { Buildings with } \\
\text { Dedicated } \\
\text { Meters }\end{array}$ & \begin{tabular}{c|} 
Cumulative $\%$ of \\
"Appropriate" \\
Buildings \\
Metered
\end{tabular} & \\
\hline 2012 Report & 69 & 41 & $\begin{array}{r}59,987,601 \\
\end{array}$ & $\begin{array}{r}0 \\
\end{array}$ & 39 & \begin{tabular}{|r|}
$48,721,248$ \\
\end{tabular} & 0 & 80.0 & $115.9 \%$ & $49.0 \%$ \\
\hline 2013 Planned & 70 & 25 & $42,043,647$ & 0 & 124 & $117,050,073$ & 0 & 149.0 & $212.9 \%$ & $70.0 \%$ \\
\hline 2014 Planned & 71 & 25 & $42,043,647$ & 0 & 125 & $124,471,361$ & 0 & 150.0 & $211.3 \%$ & $71.0 \%$ \\
\hline 2015 Planned & 71 & 25 & $42,043,647$ & 0 & 125 & $124,471,361$ & 0 & 150.0 & $211.3 \%$ & $71.0 \%$ \\
\hline
\end{tabular}

Note: The increase in meters installed in FY 2013 is wholly dependent upon funding and the decision to meter many NE buil dings to compens ate for EM buil dings not metered - EF 11/27/12

1-5b. EISA 2007 Metering Of Natural Gas Use

(Note: If a buil ding has an advanced and a standard meter, only account for the advanced meter. If a buil ding has multiple meters, ensure the utility metered is accounted/reported only once)

\begin{tabular}{|c|c|c|c|c|c|c|c|c|c|c|}
\hline \multirow[b]{2}{*}{ Fiscal Year } & \multirow{2}{*}{\begin{tabular}{|c|} 
\# of \\
"Appropriate \\
"Buildings \\
Per EPAct \\
2005
\end{tabular}} & \multicolumn{3}{|c|}{ Standard Meters } & \multicolumn{3}{|c|}{ Advanced Meters } & \multicolumn{2}{|c|}{ Total } & \multirow[b]{2}{*}{$\begin{array}{c}\text { Total \% of } \\
\text { Natural Gas } \\
\text { Metered }\end{array}$} \\
\hline & & $\begin{array}{c}\text { \# of Buildings } \\
\text { with Standard } \\
\text { Meters }\end{array}$ & $\begin{array}{c}\text { Estimated Amount } \\
\text { of Purchased } \\
\text { Natural Gas } \\
\text { Metered (CF/Yr) } \\
\end{array}$ & $\begin{array}{c}\text { Estimated Amount } \\
\text { of On-Site Generate } \\
\text { Natural Gas } \\
\text { Metered (CF/Yr) } \\
\end{array}$ & $\begin{array}{c}\text { \# of Buil dings } \\
\text { with } \\
\text { Advanced } \\
\text { Meters } \\
\end{array}$ & $\begin{array}{c}\text { Estimated Amount } \\
\text { of Purchased } \\
\text { Natural G as } \\
\text { Metered (CF/Yr) } \\
\end{array}$ & $\begin{array}{c}\text { Estimated Amount } \\
\text { of On-Site Generate } \\
\text { Natural Gas } \\
\text { Metered (CF/Yr) } \\
\end{array}$ & $\begin{array}{c}\text { \# of Appropriate } \\
\text { Buildings with } \\
\text { Dedicated } \\
\text { Meters }\end{array}$ & $\begin{array}{c}\text { Cumulative } \% \text { of } \\
\text { "Appropriate" } \\
\text { Buildings } \\
\text { Metered } \\
\end{array}$ & \\
\hline 2012 Report & 31 & 31 & $25,500,000,000$ & 0 & 0 & \begin{tabular}{r|}
0 \\
\end{tabular} & 0 & 31.0 & $100.0 \%$ & $100.0 \%$ \\
\hline 2013 Planned & 32 & 32 & $26,000,000,000$ & 0 & 0 & 0 & 0 & 32.0 & $100.0 \%$ & $100.0 \%$ \\
\hline 2014 Planned & 33 & 33 & $26,500,000,000$ & 0 & 0 & 0 & 0 & 33.0 & $100.0 \%$ & $100.0 \%$ \\
\hline 2015 Planned & 33 & 33 & $26,500,000,000$ & 0 & 0 & 0 & 0 & 33.0 & $100.0 \%$ & $100.0 \%$ \\
\hline
\end{tabular}

1-5c. EISA 2007 Metering Of Steam Use

(Note: If a buil ding has an advanced and a standard meter, only account for the advanced meter. If a buil ding has multiple meters, ensure the utility metered is accounted/reported only once)

\begin{tabular}{|c|c|c|c|c|c|c|c|c|c|c|}
\hline \multirow[b]{2}{*}{ Fiscal Year } & \multirow{2}{*}{$\begin{array}{c}\text { \# of } \\
\text { "Appropriate } \\
\text { "Buildings } \\
\text { Per EPAct } \\
2005\end{array}$} & \multicolumn{3}{|c|}{ Standard Meters } & \multicolumn{3}{|c|}{ Advanced Meters } & \multicolumn{2}{|c|}{ Total } & \multirow[b]{2}{*}{$\begin{array}{c}\text { Total \% of } \\
\text { Steam } \\
\text { Metered }\end{array}$} \\
\hline & & $\begin{array}{c}\text { \# of Buildings } \\
\text { with Standard } \\
\text { Meters }\end{array}$ & \begin{tabular}{|l} 
Estimated Am ount \\
of Purchased Steam \\
Metered (Btu/Yr)
\end{tabular} & \begin{tabular}{|c|}
$\begin{array}{c}\text { Estimated Amount } \\
\text { of On-Site Generate } \\
\text { Steam Metered } \\
\text { (Btu/Yr) }\end{array}$ \\
\end{tabular} & $\begin{array}{c}\text { \# of Buildings } \\
\text { with } \\
\text { Advanced } \\
\text { Meters } \\
\end{array}$ & $\begin{array}{l}\text { Estimated Amount } \\
\text { of Purchased Steam } \\
\text { Metered (Btu } Y \mathrm{r} \text { ) }\end{array}$ & \begin{tabular}{|c|}
$\begin{array}{c}\text { Estim ated Amount } \\
\text { of On-Site Generate } \\
\text { Steam Metered } \\
(\mathrm{Btu} / \mathrm{Yr})\end{array}$ \\
\end{tabular} & $\begin{array}{c}\text { \# of Appropriate } \\
\text { Buildings with } \\
\text { Dedicated } \\
\text { Meters }\end{array}$ & $\begin{array}{l}\text { Cumulative \% of } \\
\text { "Appropriate" } \\
\text { Buildings } \\
\text { Metered } \\
\end{array}$ & \\
\hline 2012 Report & 0 & 0 & 0 & 0 & 0 & 0 & 0 & 0.0 & \#DIV/01 & $0.0 \%$ \\
\hline 2013 Planned & 0 & 0 & 0 & 0 & 0 & 0 & 0 & 0.0 & \#DIV/01 & $0.0 \%$ \\
\hline 2014 Planned & 0 & 0 & 0 & 0 & 0 & 0 & 0 & 0.0 & \#DIV/0! & $0.0 \%$ \\
\hline 2015 Planned & 0 & 0 & 0 & 0 & 0 & 0 & 0 & 0.0 & \#DIV/on & $0.0 \%$ \\
\hline
\end{tabular}

1-5d. DOE O 436.1 \& SSPP Metering Of Chilled Water Use

(Note: If a building has an advanced and a standard meter, only account for the advanced meter. If a buil ding has multiple meters, ensure the utility metered is accounted/reported only once)

\begin{tabular}{|c|c|c|c|c|c|c|c|c|c|c|}
\hline \multirow[b]{2}{*}{ Fiscal Year } & \multirow{2}{*}{\begin{tabular}{|c|} 
\# of \\
"Appropriate \\
"Buildings \\
Per EPAct \\
2005
\end{tabular}} & \multicolumn{3}{|c|}{ Standard Meters } & \multicolumn{3}{|c|}{ Advanced Meters } & \multicolumn{2}{|c|}{ Total } & \multirow[b]{2}{*}{$\begin{array}{c}\text { Total } \% \text { of } \\
\text { Chilled } \\
\text { Water } \\
\text { Metered }\end{array}$} \\
\hline & & $\begin{array}{c}\text { \# of Buildings } \\
\text { with Standard } \\
\text { Meters }\end{array}$ & $\begin{array}{c}\text { Estimated Amount } \\
\text { of Purchased } \\
\text { Chilled Water } \\
\text { Metered (Btu/Yr) }\end{array}$ & $\begin{array}{c}\text { Estimated Amount } \\
\text { of On-Site Generate } \\
\text { Chilled Water } \\
\text { Metered (Btu/Yr) } \\
\end{array}$ & $\begin{array}{c}\text { \# of Buildings } \\
\text { with } \\
\text { Advanced } \\
\text { Meters } \\
\end{array}$ & $\begin{array}{c}\text { Estimated Amount } \\
\text { of Purchased } \\
\text { Chilled Water } \\
\text { Metered (Btu/Yr) }\end{array}$ & $\begin{array}{c}\text { Estimated Amount } \\
\text { of On-Site Generate } \\
\text { Chilled Water } \\
\text { Metered (Btu/Yr) } \\
\end{array}$ & $\begin{array}{c}\text { \# of Appropriate } \\
\text { Buildings with } \\
\text { Dedicated } \\
\text { Meters }\end{array}$ & $\begin{array}{l}\text { Cumulative \% of } \\
\text { "Appropriate" } \\
\text { Buildings } \\
\text { Metered } \\
\end{array}$ & \\
\hline 2012 Report & 0 & 0 & 0 & 0 & 0 & 0 & 0 & $\begin{array}{r}0.0 \\
\end{array}$ & \#DIV/0 & $0.0 \%$ \\
\hline 2013 Planned & 0 & 0 & 0 & 0 & 0 & 0 & 0 & 0.0 & \#DIV/0 & $0.0 \%$ \\
\hline 2014 Planned & 0 & 0 & 0 & 0 & 0 & 0 & 0 & 0.0 & \#DIV/01 & $0.0 \%$ \\
\hline 2015 Planned & 0 & 0 & 0 & 0 & 0 & 0 & 0 & 0.0 & \#DIV/01 & $0.0 \%$ \\
\hline
\end{tabular}

1-5e. Water Managem ent Best Practice Metering Of Water Use

(Note: If a buil ding has an advanced and a standard meter, only account for the advanced meter. If a buil ding has multiple meters, ensure the utility metered is accounted/reported only once)

\begin{tabular}{|c|c|c|c|c|c|c|c|c|c|c|}
\hline \multirow[b]{2}{*}{ Fiscal Year } & \multirow{2}{*}{$\begin{array}{l}\text { \# of } \\
\text { "Appropriate } \\
\text { "Buildings } \\
\text { Per EPAct } \\
2005\end{array}$} & \multicolumn{3}{|c|}{ Standard Meters } & \multicolumn{3}{|c|}{ Advanced Meters } & \multicolumn{2}{|c|}{ Total } & \multirow[b]{2}{*}{$\begin{array}{c}\text { Total } \% \text { of } \\
\text { Water } \\
\text { Metered }\end{array}$} \\
\hline & & $\begin{array}{l}\text { \# of Buildings } \\
\text { with Standard } \\
\text { Meters }\end{array}$ & $\begin{array}{c}\text { Estim ated Amount } \\
\text { of Purchased Water } \\
\text { Metered (Gal/Yr) }\end{array}$ & \begin{tabular}{|c|}
$\begin{array}{c}\text { Estimated Amount } \\
\text { of On-Site Captured } \\
\text { Water Metered } \\
\left(\mathrm{Gal} / \mathrm{Yr}_{\mathrm{r}}\right)\end{array}$ \\
\end{tabular} & \begin{tabular}{|c|} 
\# of Buildings \\
with \\
Advanced \\
Meters
\end{tabular} & $\begin{array}{c}\text { Estimated Amount } \\
\text { of Purchased Water } \\
\text { Metered (Gal/Yr) }\end{array}$ & \begin{tabular}{|c|}
$\begin{array}{c}\text { Estimated Amount } \\
\text { of On-Site Captur ed } \\
\text { Water Metered } \\
\text { (Gal/Yr) }\end{array}$ \\
\end{tabular} & $\begin{array}{c}\text { \# of Appropriate } \\
\text { Buildings with } \\
\text { Dedicated } \\
\text { Meters }\end{array}$ & $\begin{array}{l}\text { Cumulative \% of } \\
\text { "Appropriate" } \\
\text { Buildings } \\
\text { Metered } \\
\end{array}$ & \\
\hline 2012 Report & 16 & 16 & $40,000,000$ & 0 & 0 & 0 & 0 & 16.0 & $100.0 \%$ & $4.7 \%$ \\
\hline 2013 Planned & 17 & 17 & $46,000,000$ & 0 & 0 & 0 & 0 & 17.0 & $100.0 \%$ & $5.4 \%$ \\
\hline 2014 Planned & 18 & 18 & $52,000,000$ & 0 & 0 & 0 & 0 & 18.0 & $100.0 \%$ & $6.1 \%$ \\
\hline 2015 Planned & 18 & 18 & $52,000,000$ & 0 & 0 & 0 & 0 & 18.0 & $100.0 \%$ & $6.1 \%$ \\
\hline
\end{tabular}




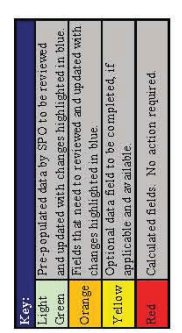

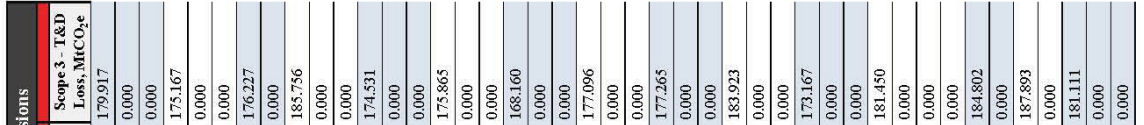

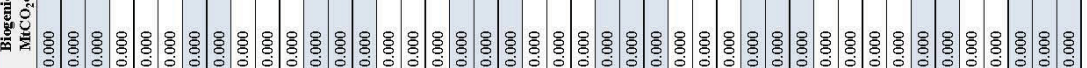
要,

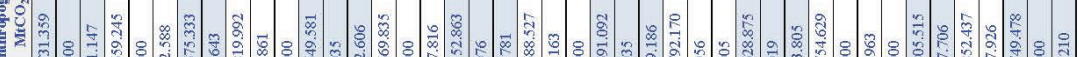

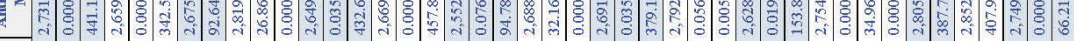
颜.

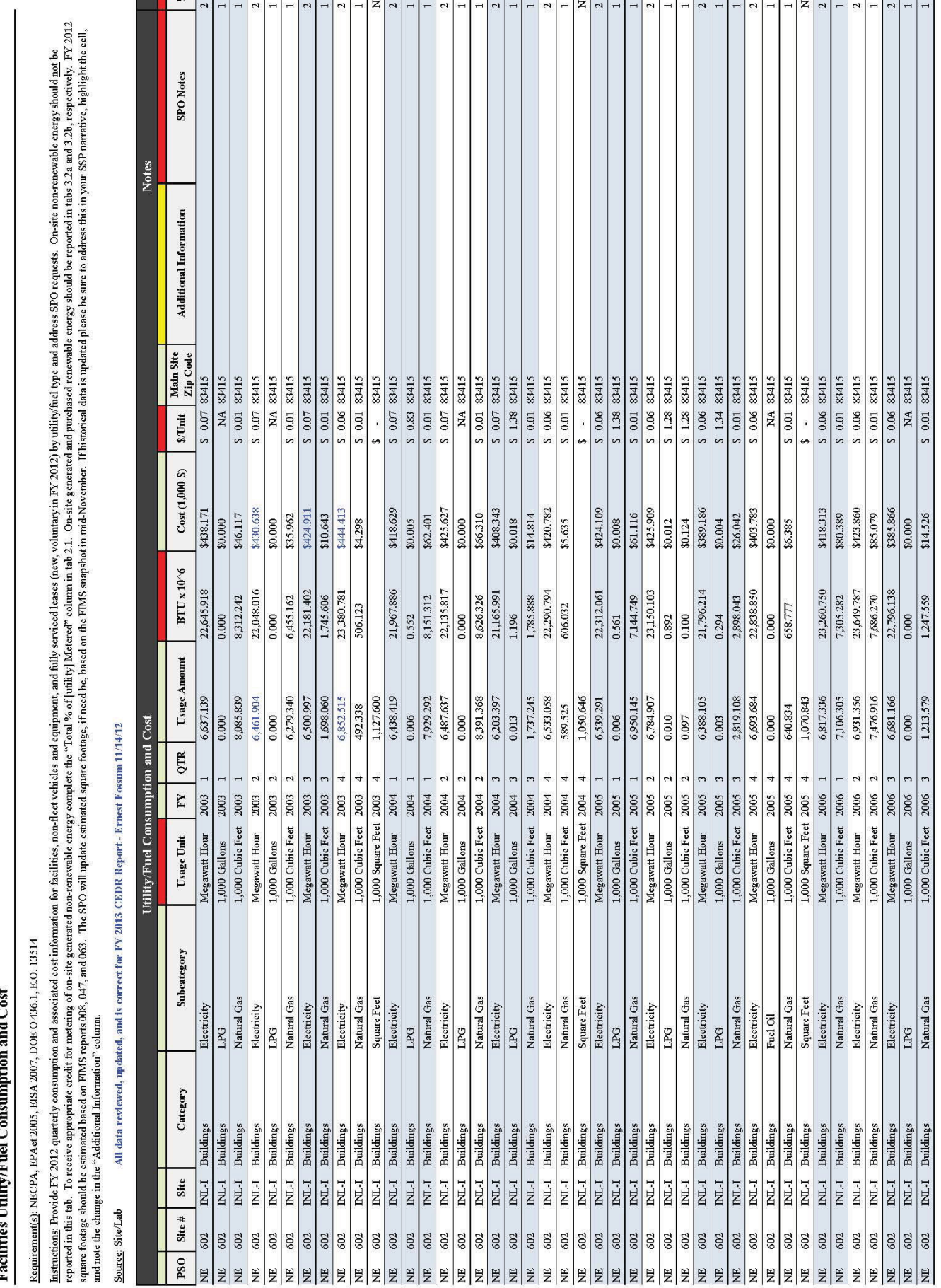




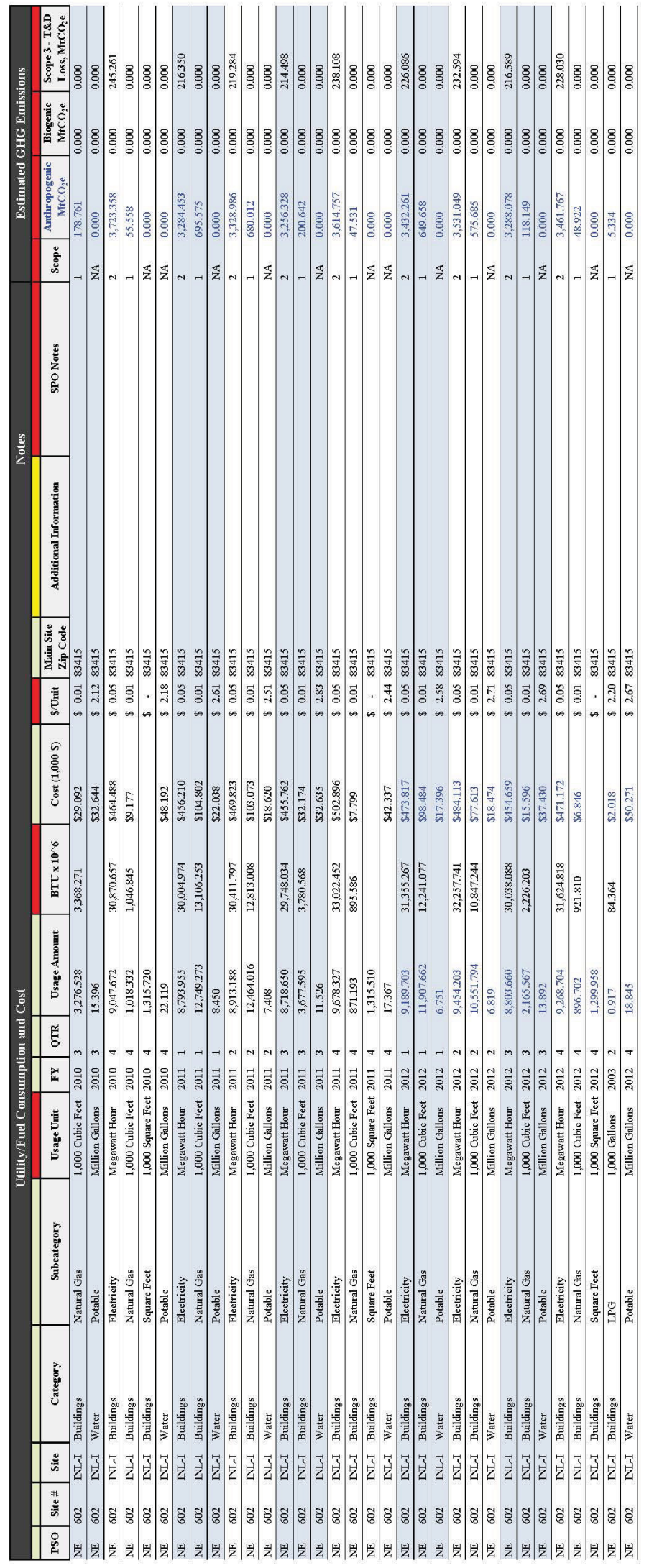




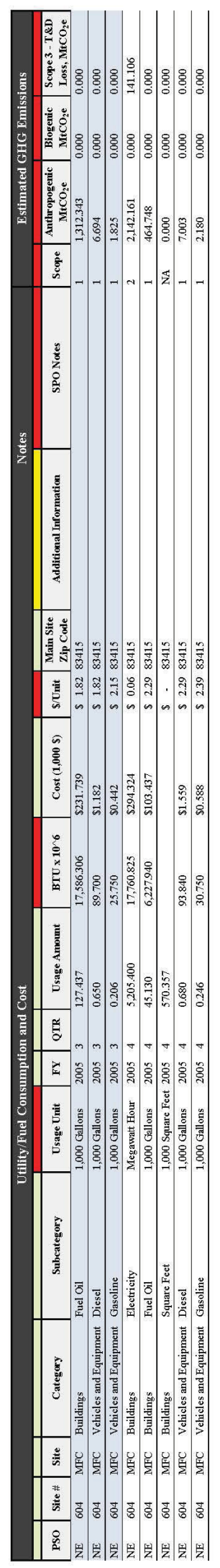



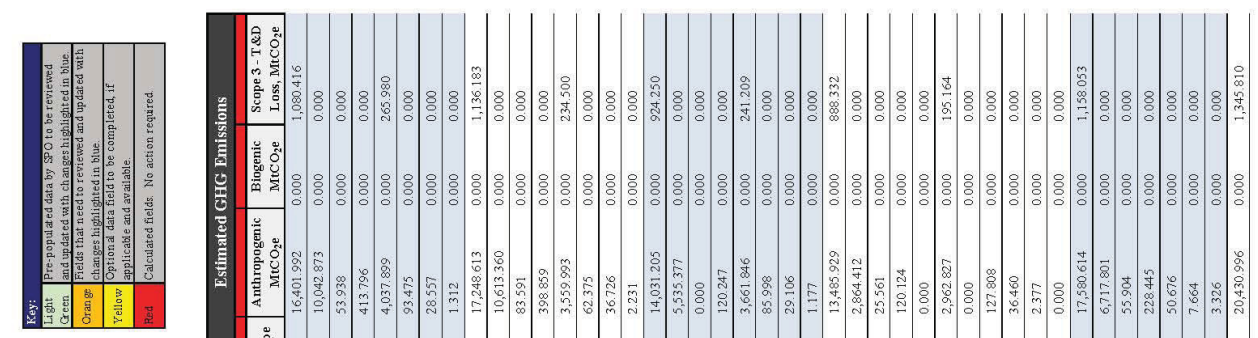

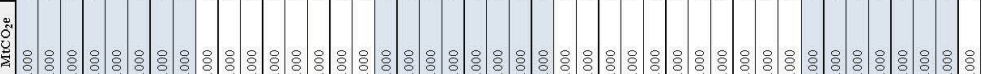

t)

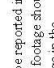

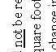

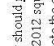

初出高

离

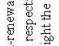

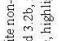

9.

*

8.

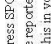

물

v

疍器

焉要

要

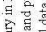

高变

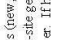

设

牙过

㲾

昰高

管墨

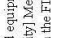

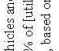

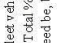

政彭

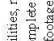

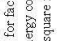

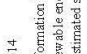

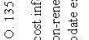

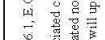

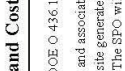

然

용

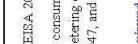

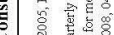

要

藏 50

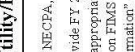

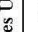

氮

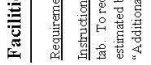

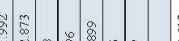

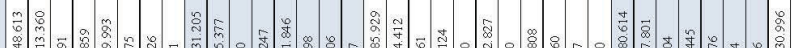

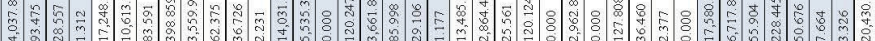

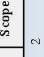

:

हू.

$\frac{20}{20}$

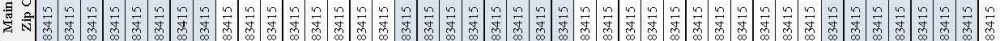

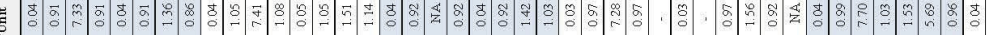

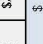

要

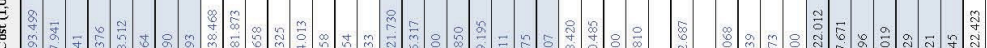

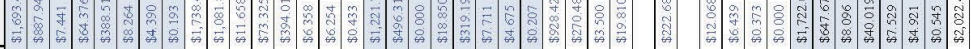

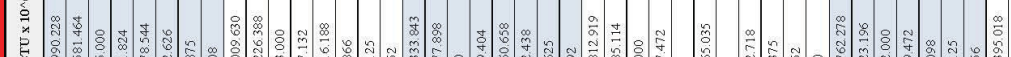

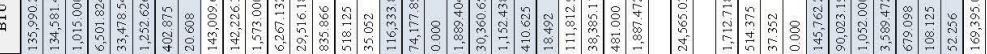

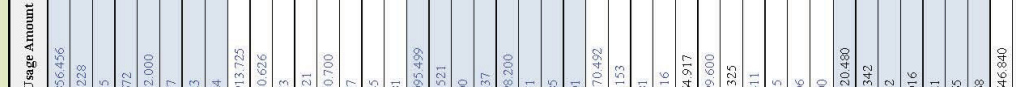

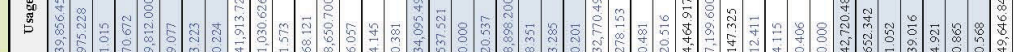

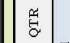

\$ $\stackrel{5}{5}$

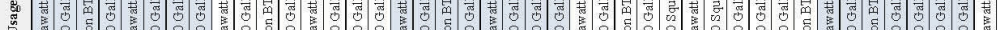

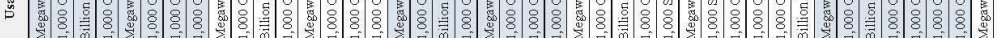

.

赔.

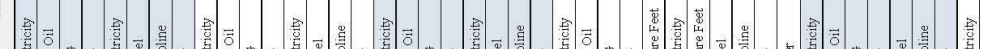

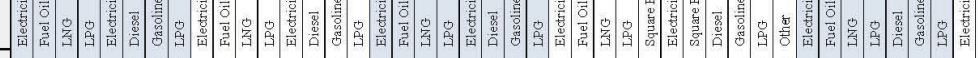

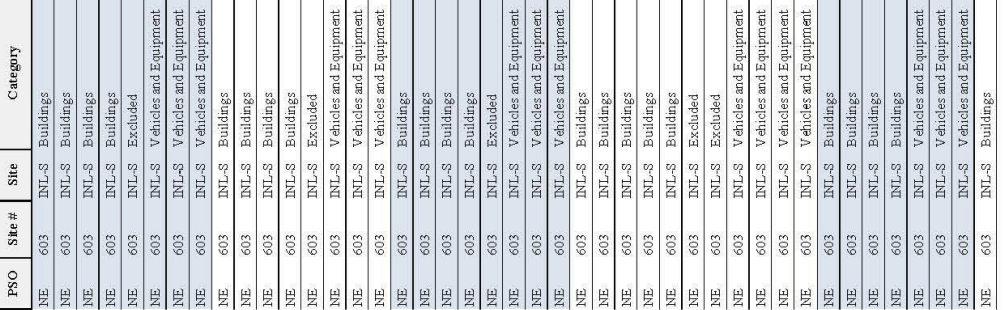




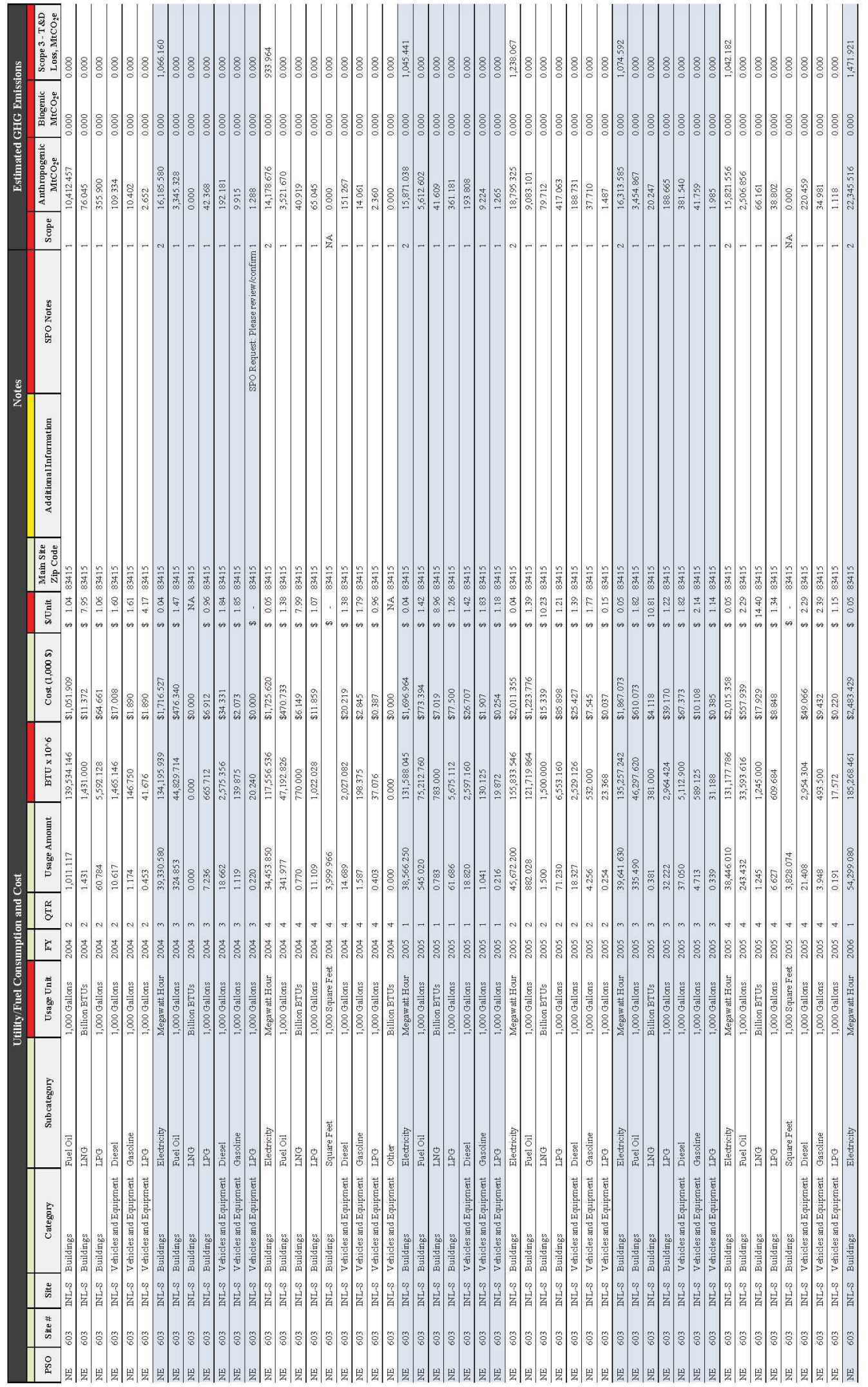




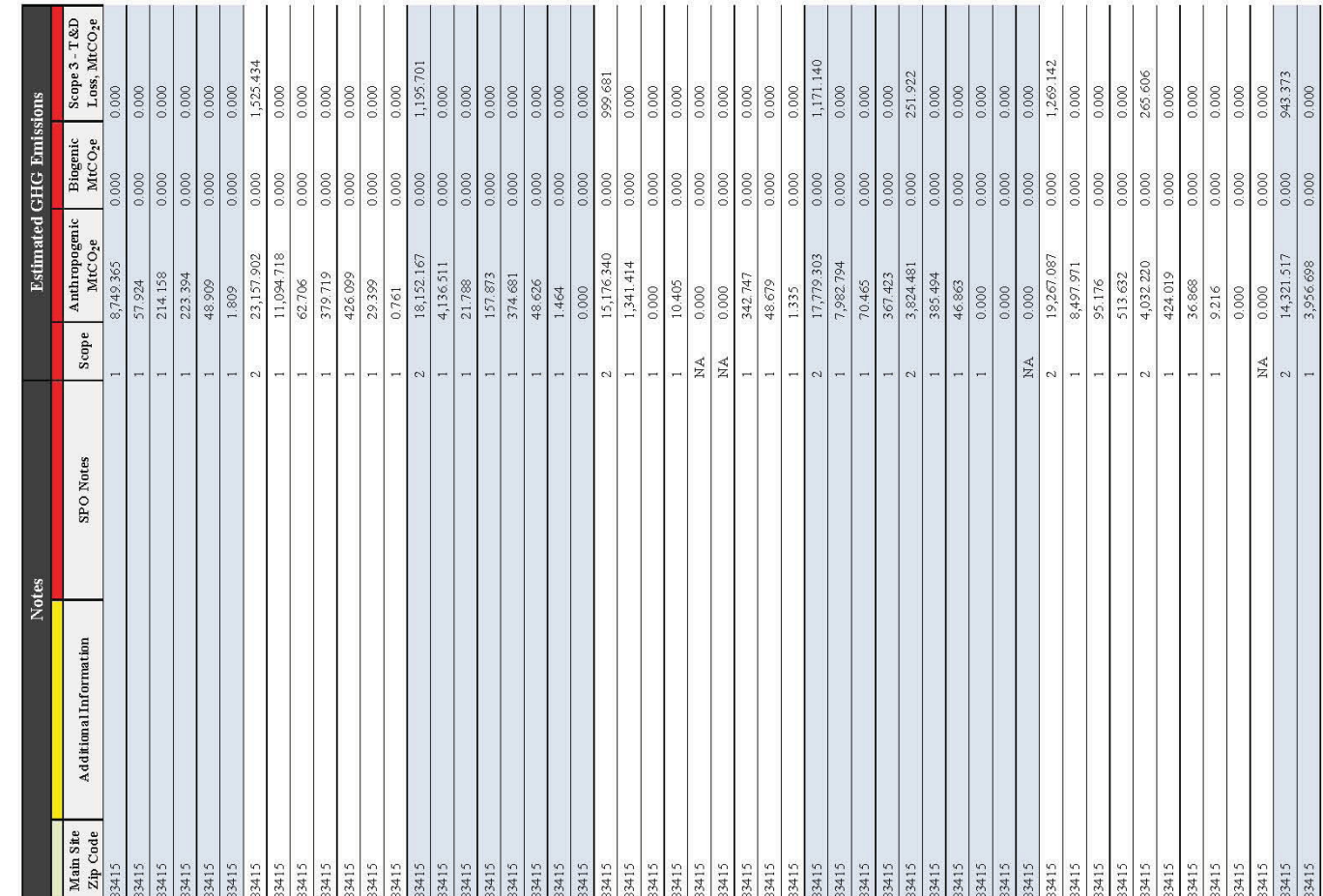
套

\begin{tabular}{l}
$\overline{6}$ \\
8 \\
\hdashline
\end{tabular}

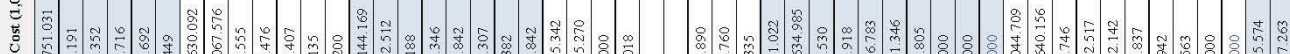

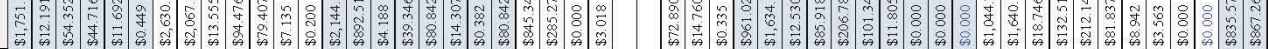

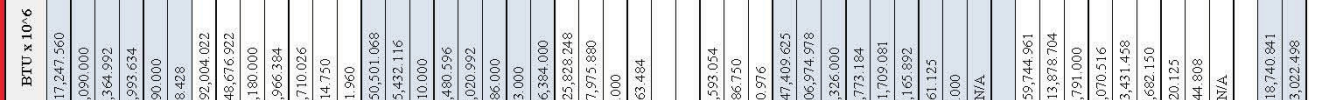

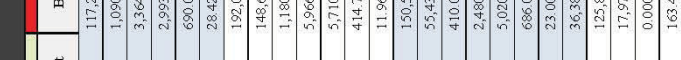

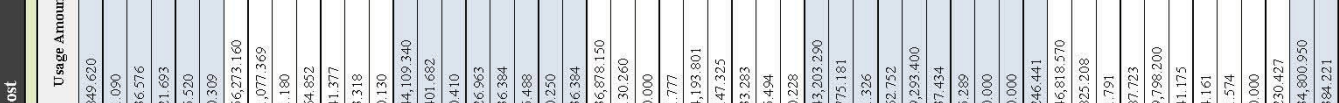

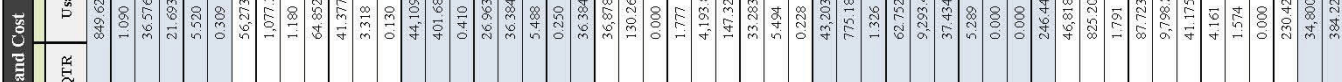

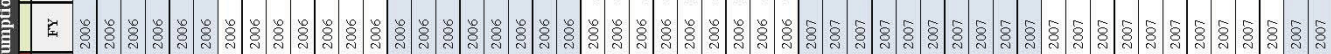

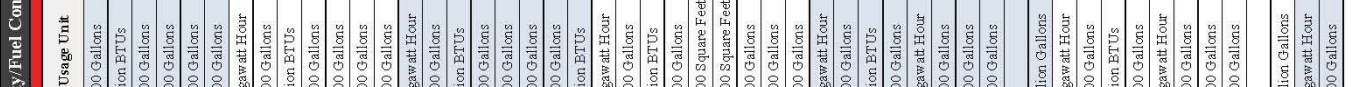

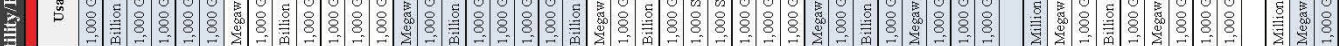

窟

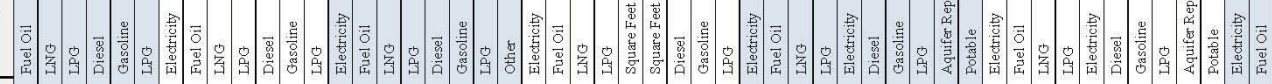

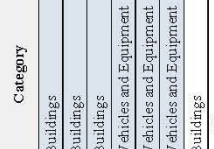

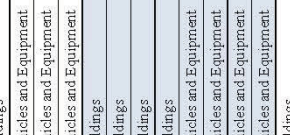

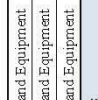

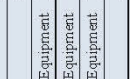

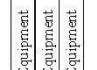

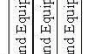
5. 5.

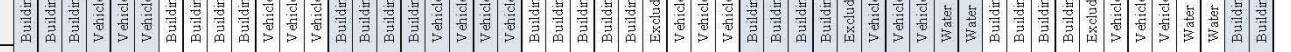

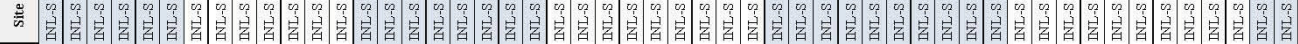 䔄

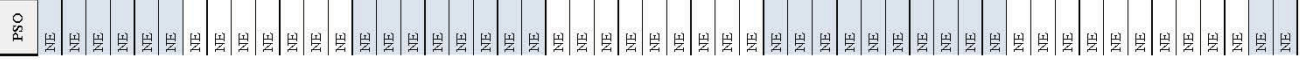




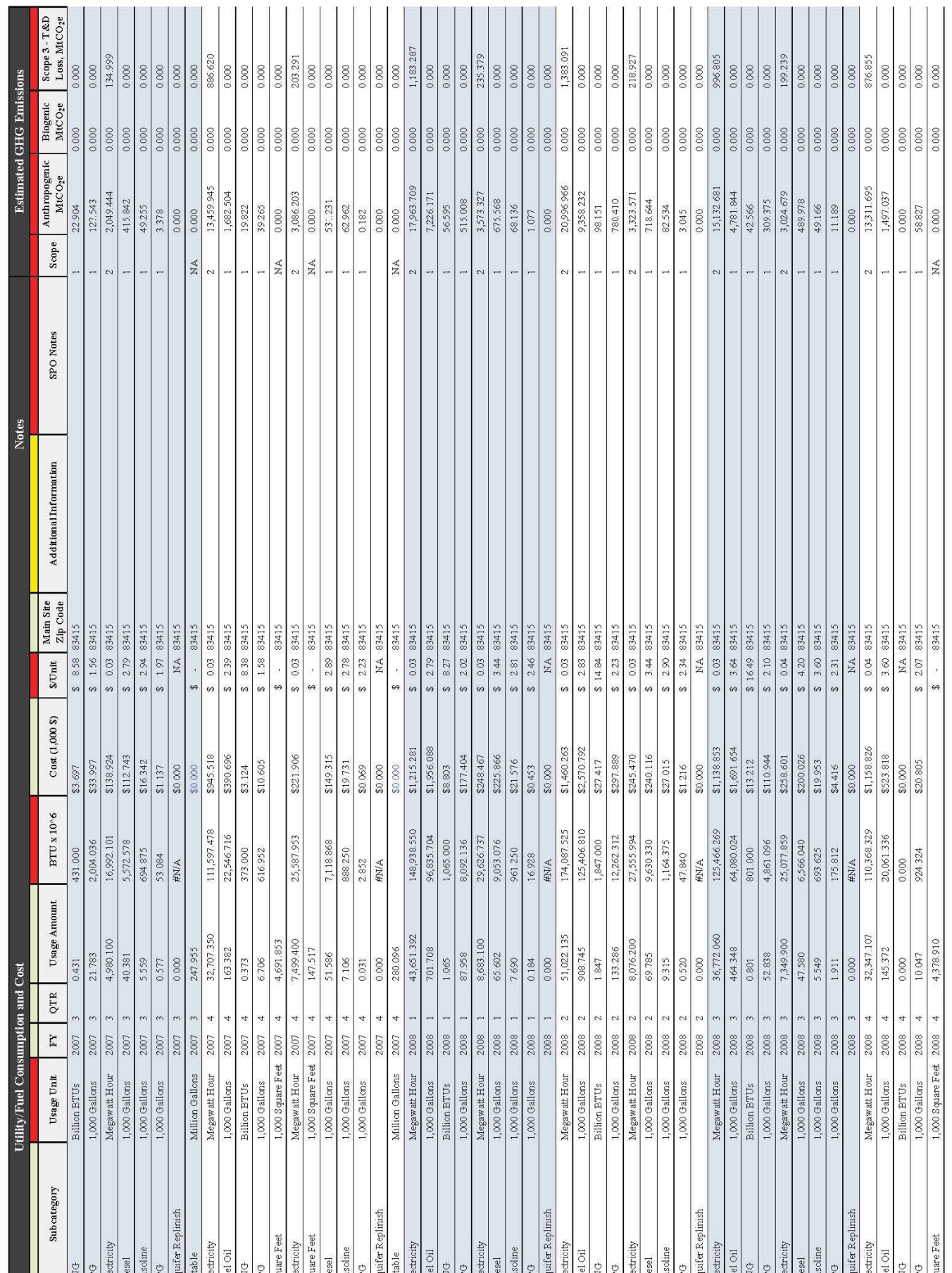

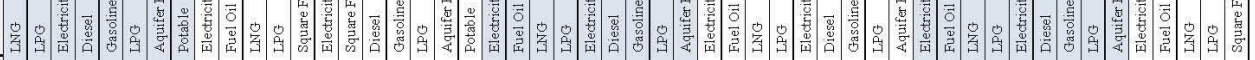

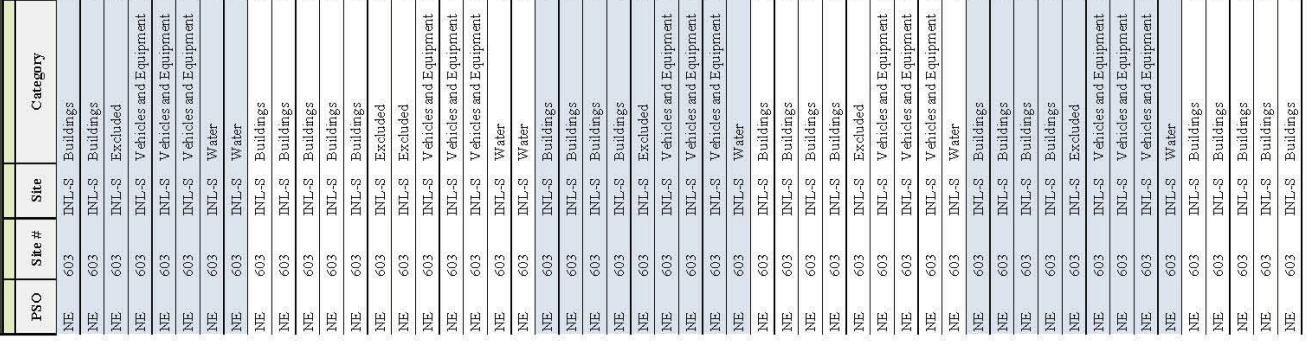




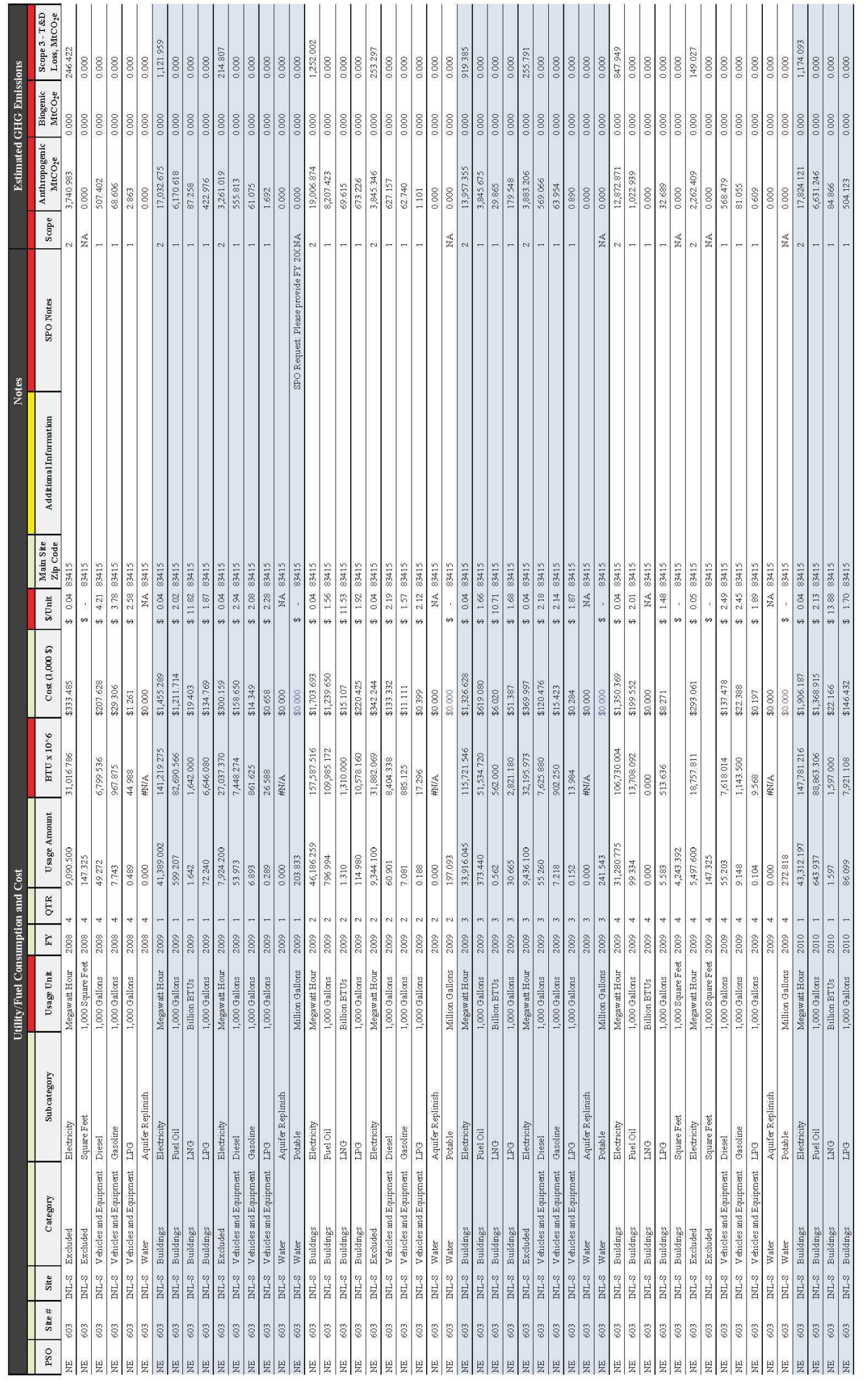




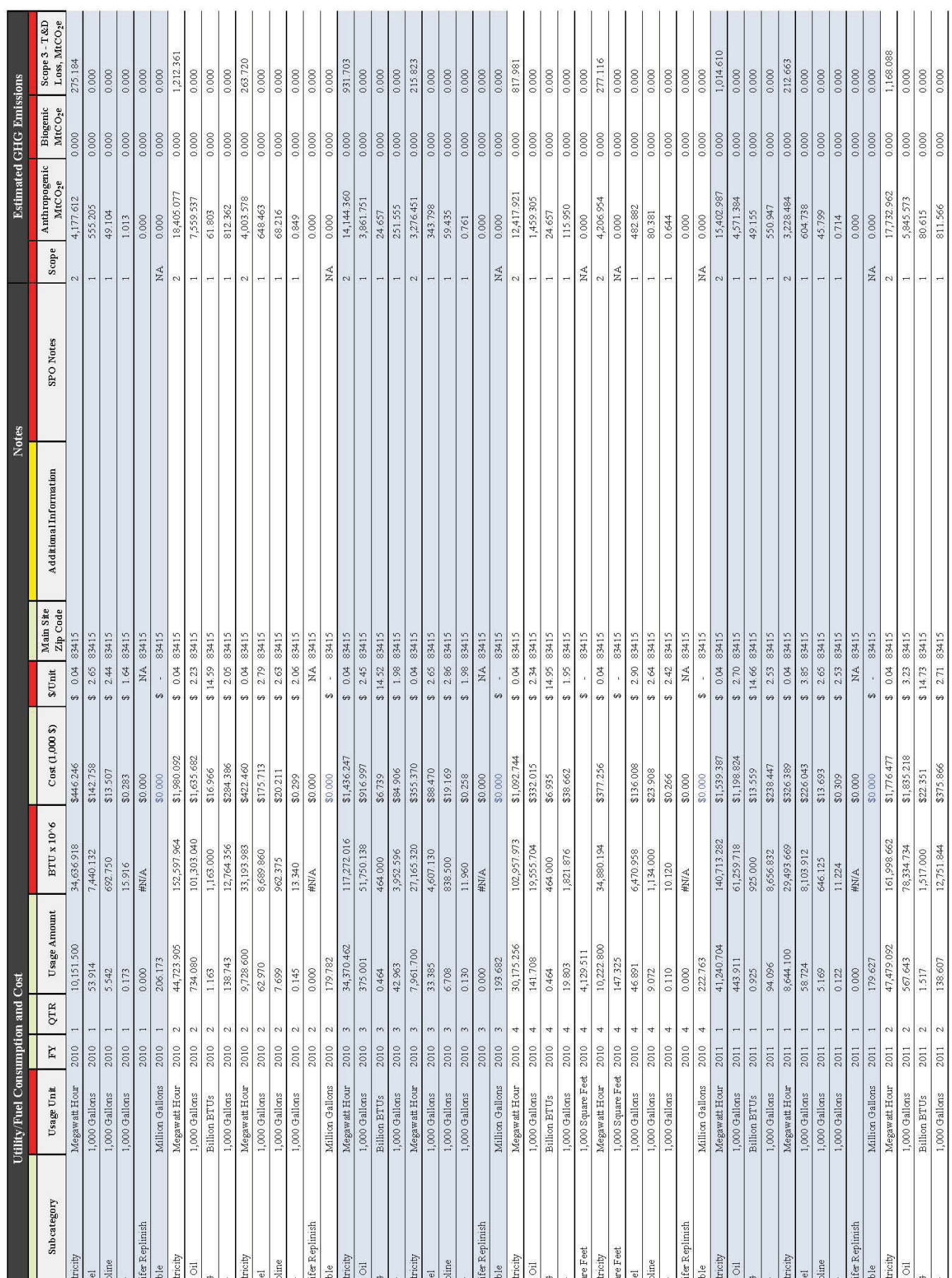

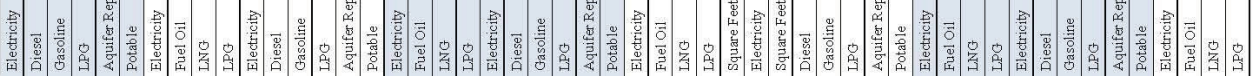

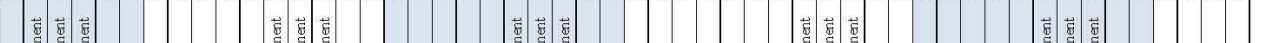

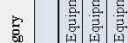

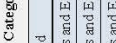

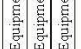

商部部

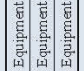

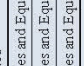

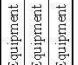

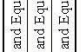

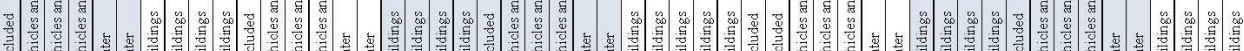

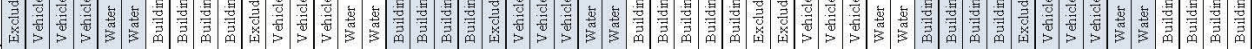

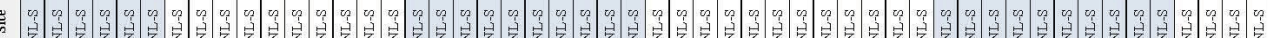

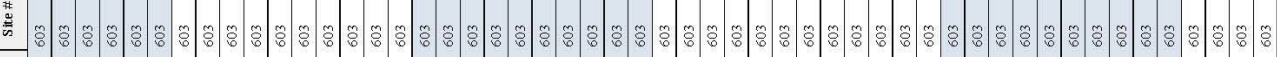

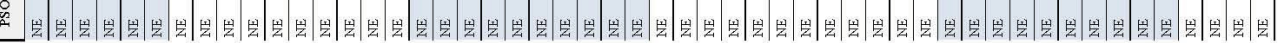




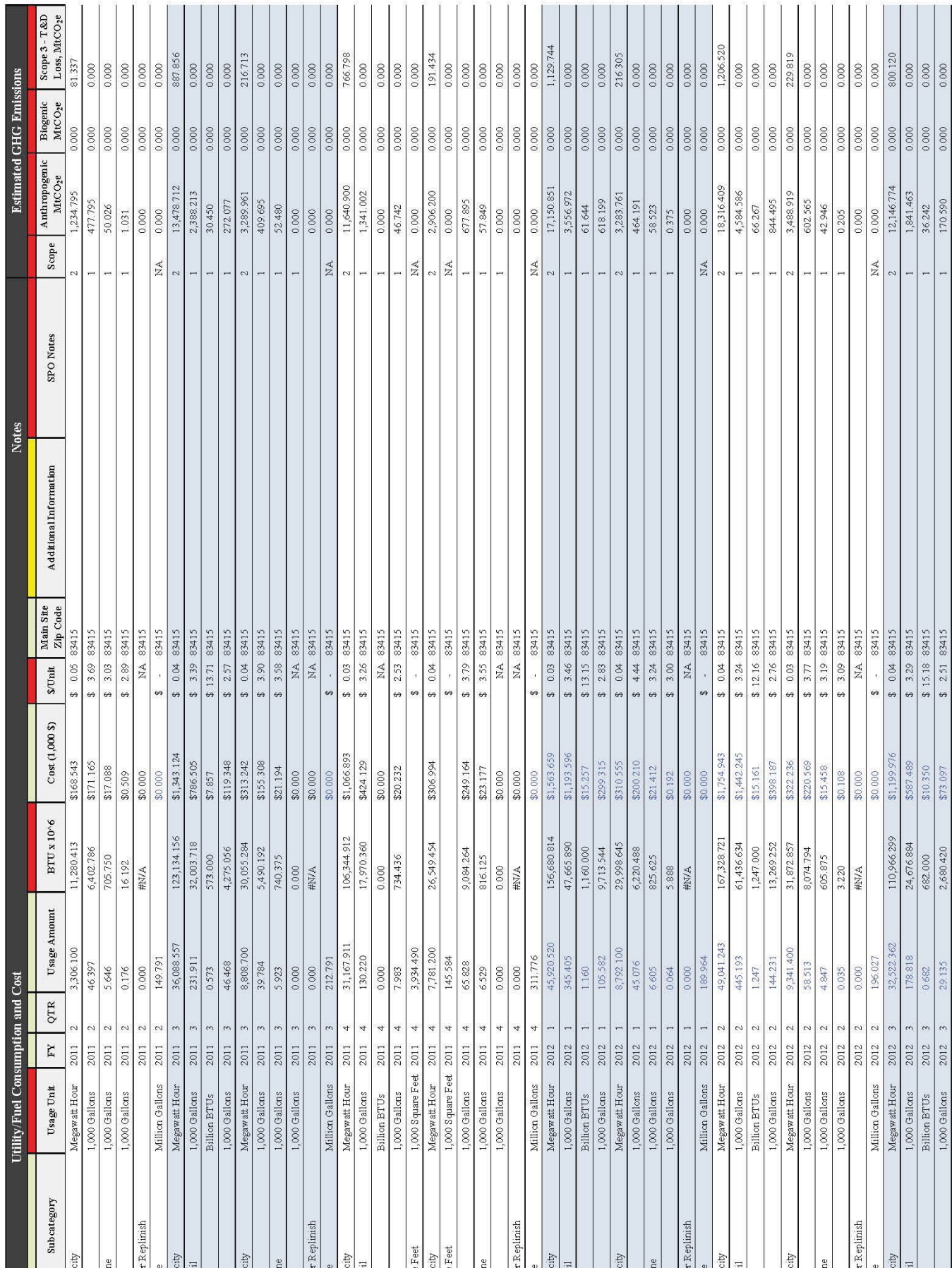

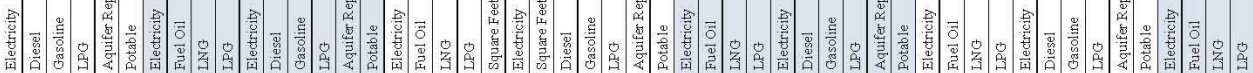

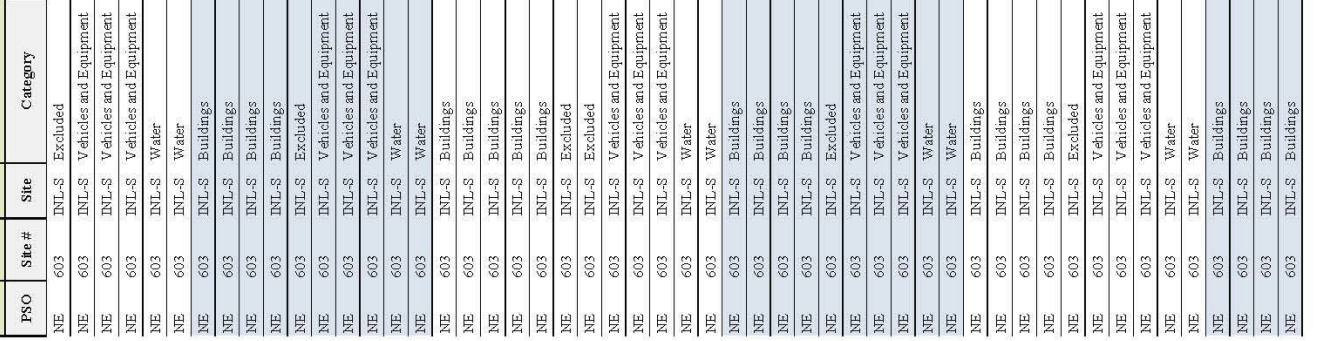




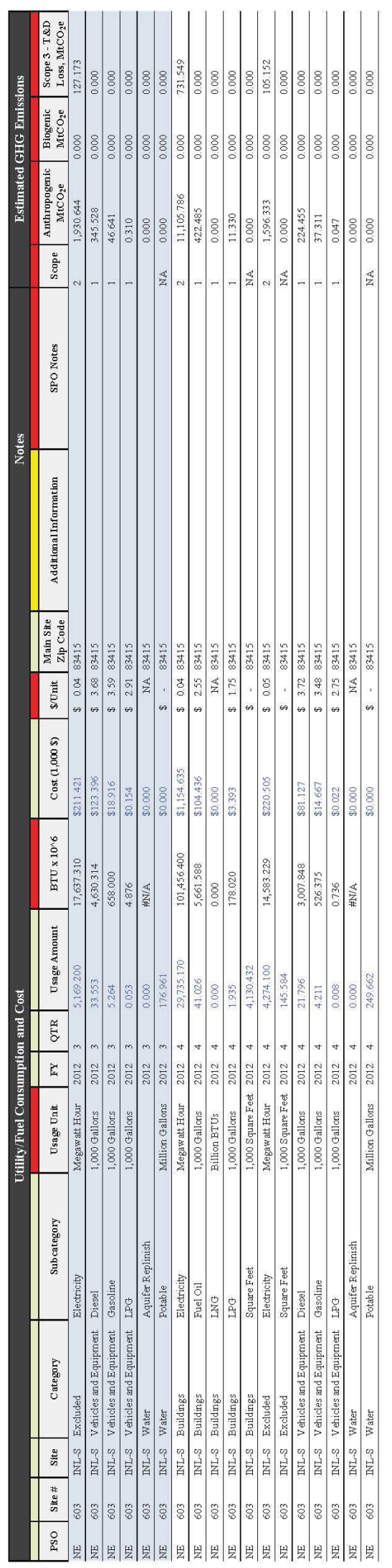




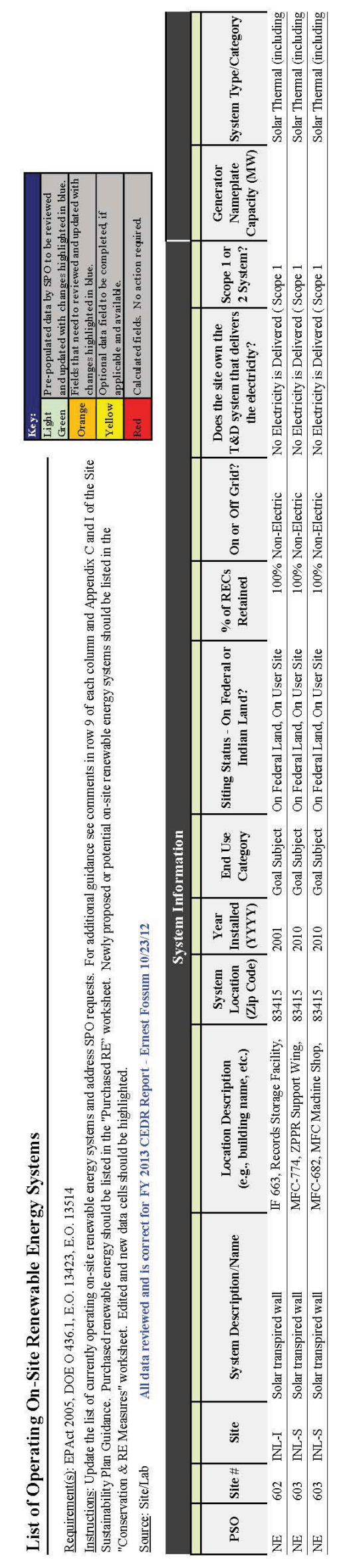

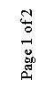

5

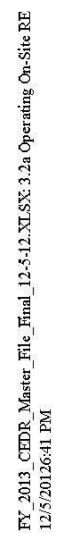




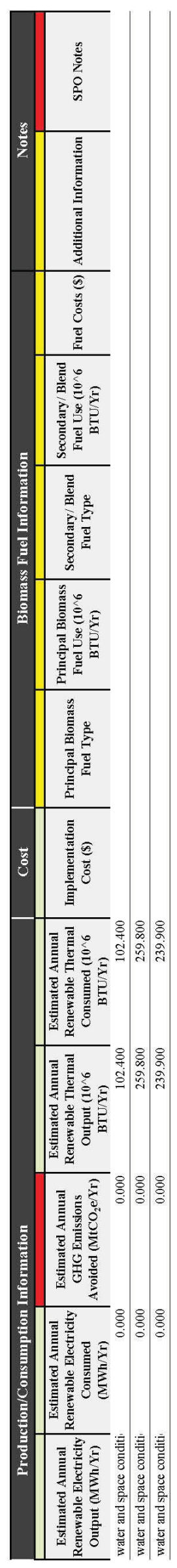




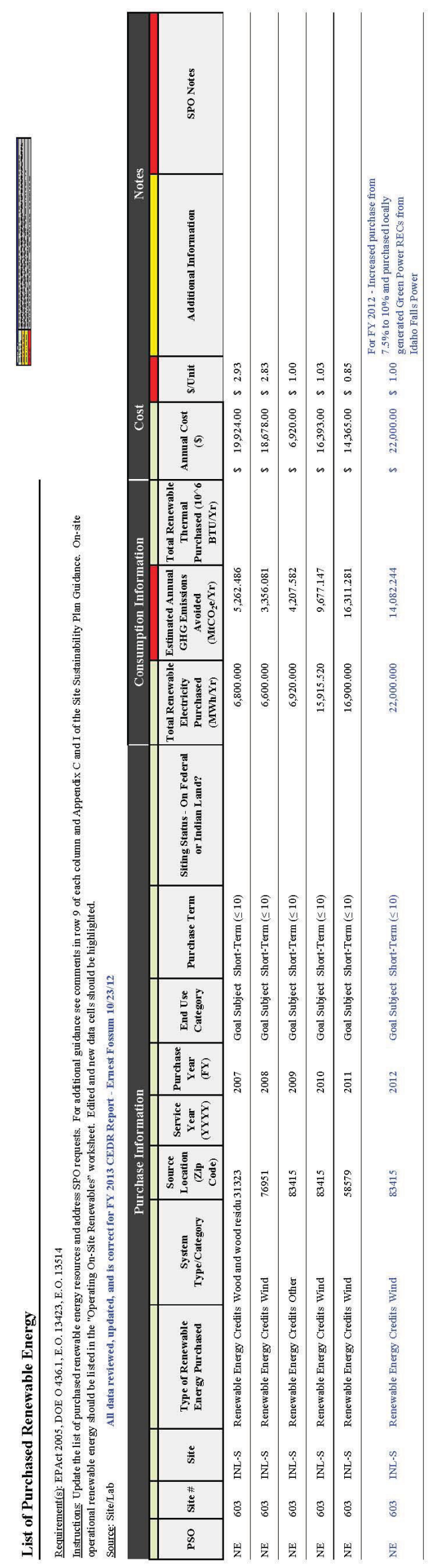




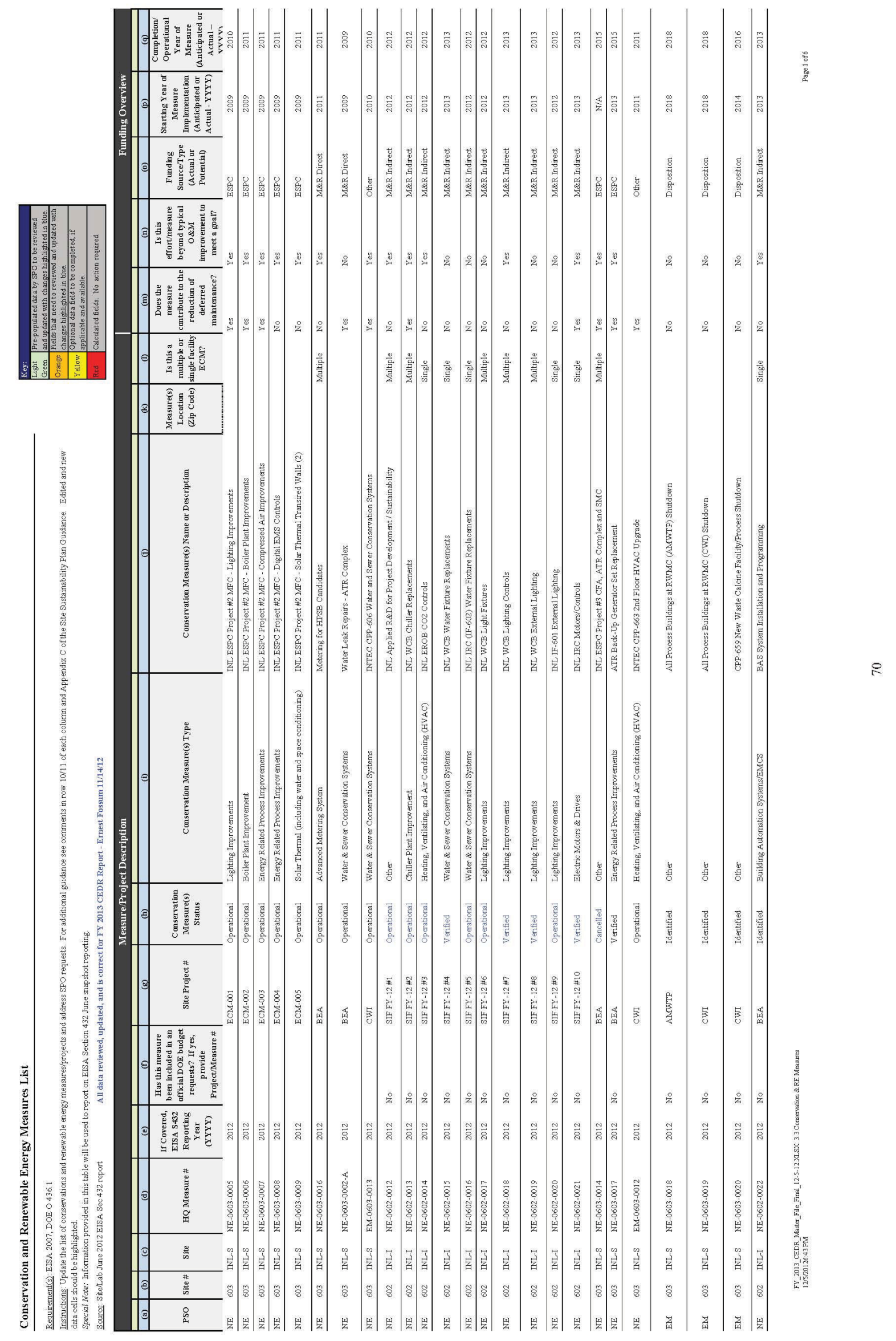




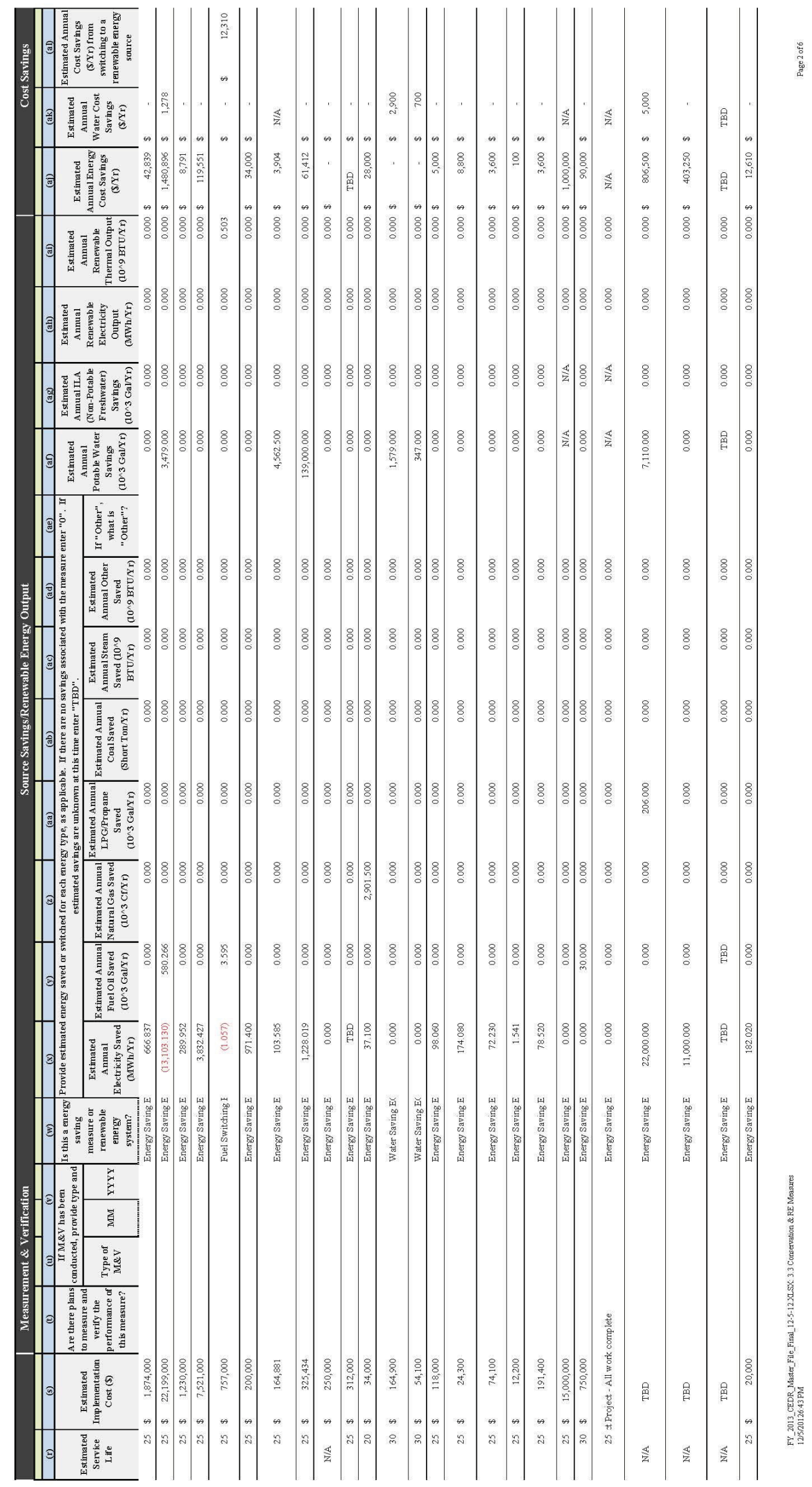




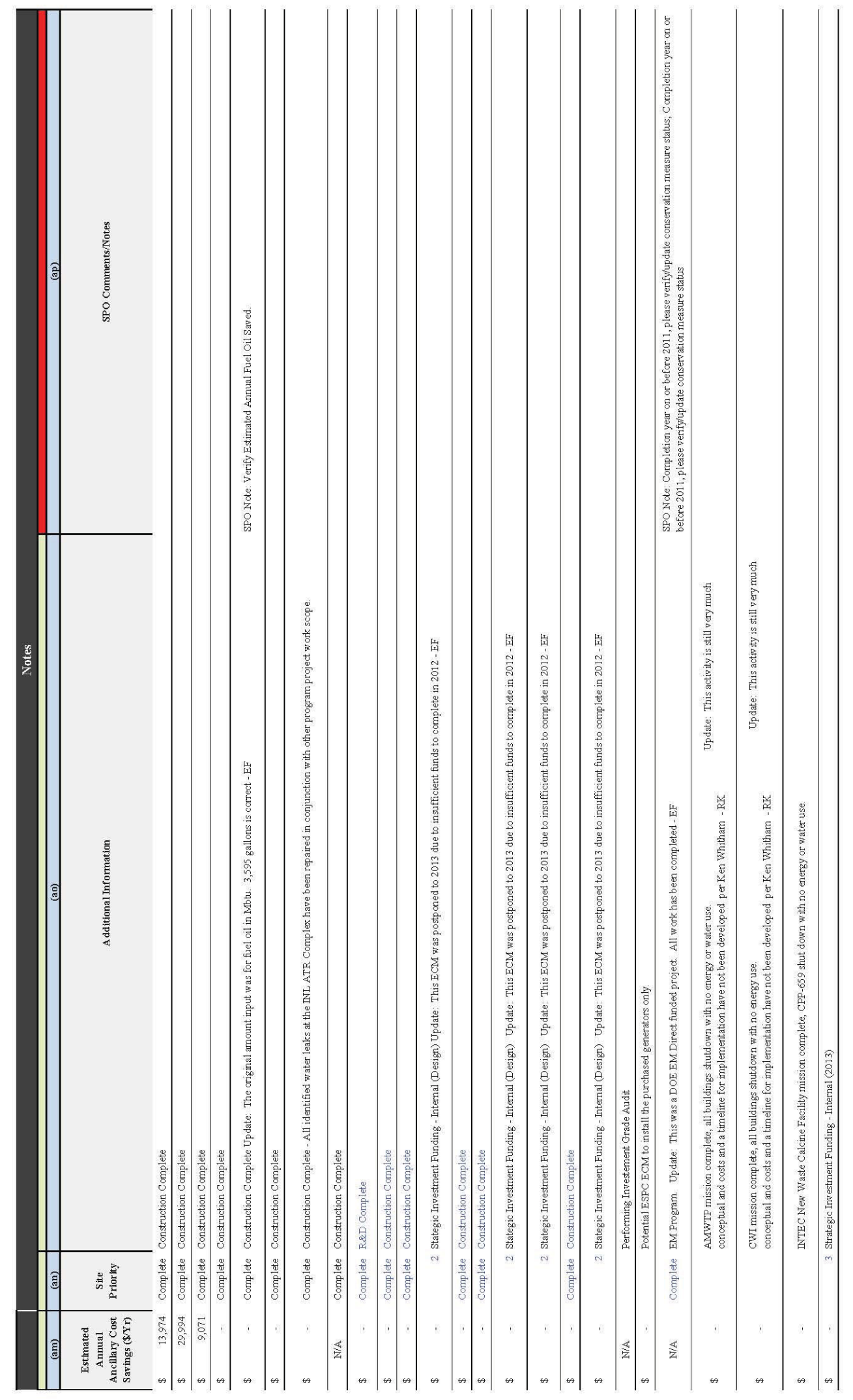




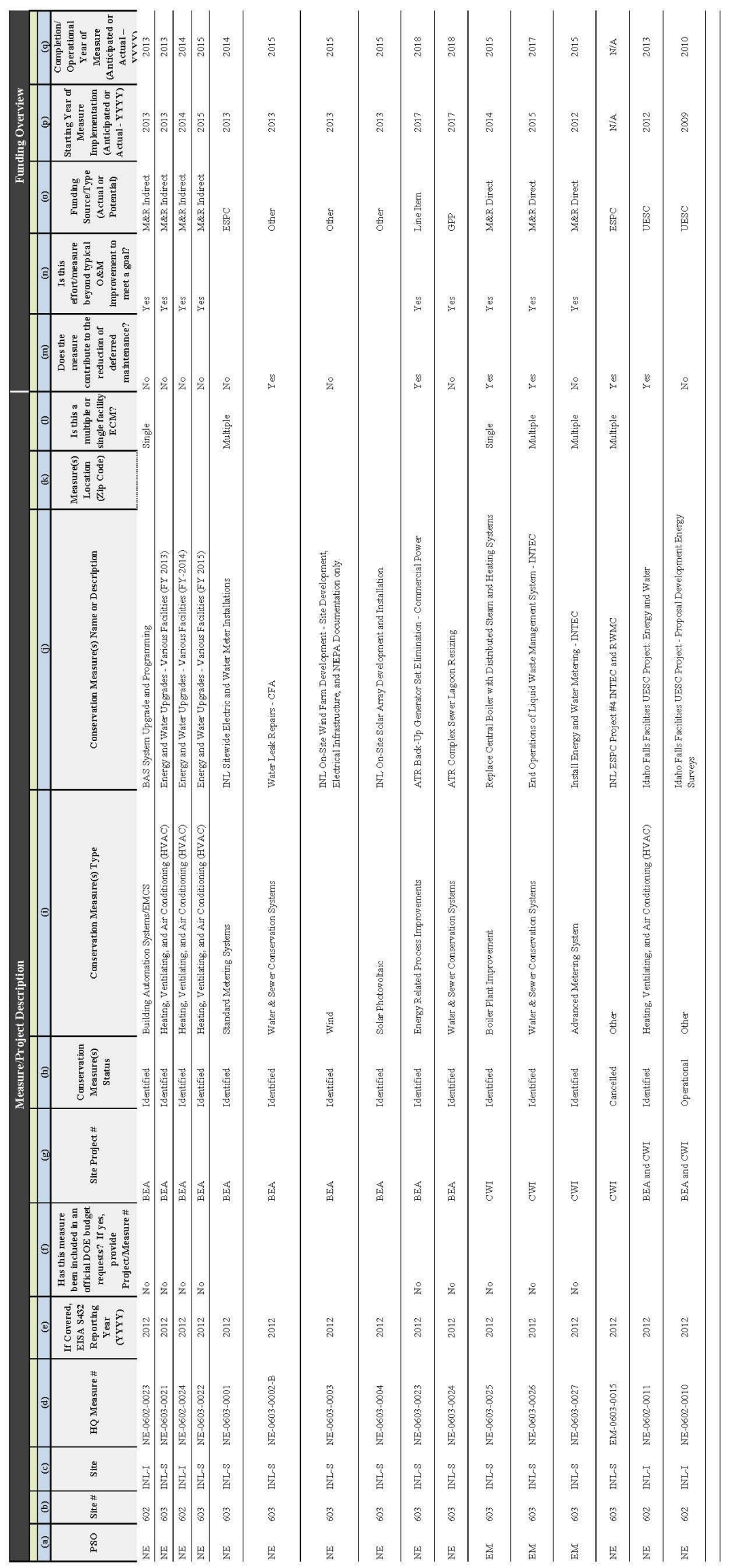

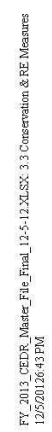




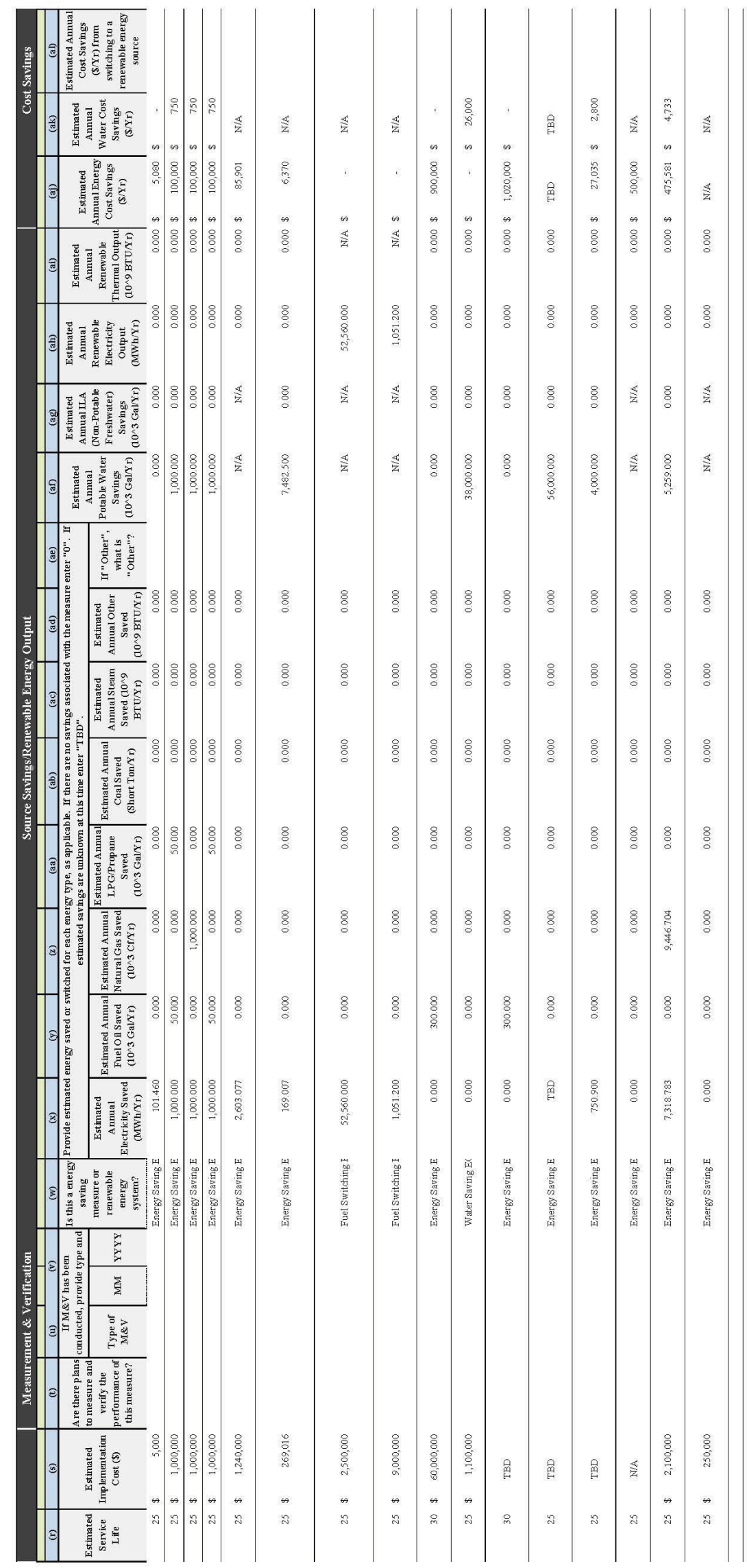




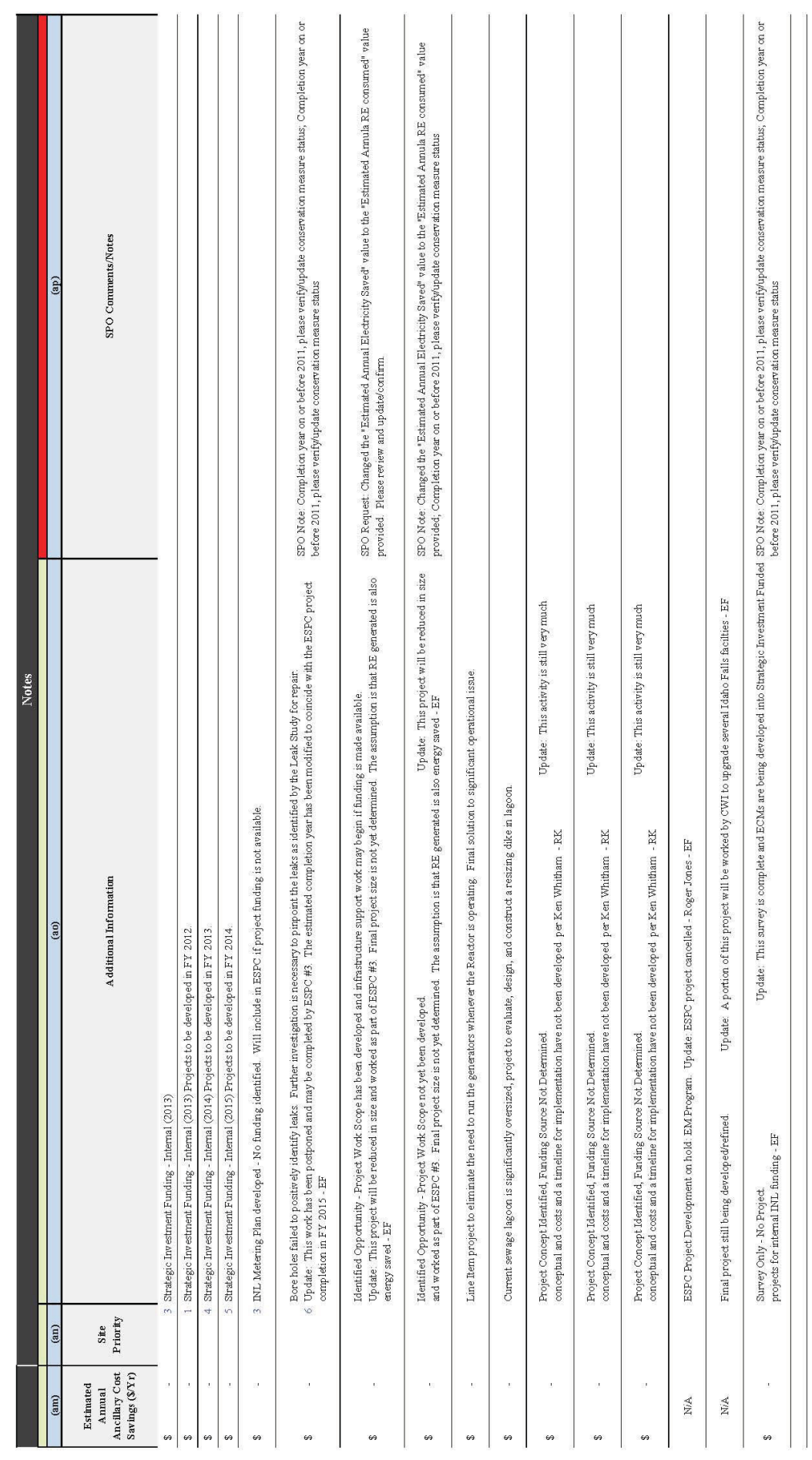




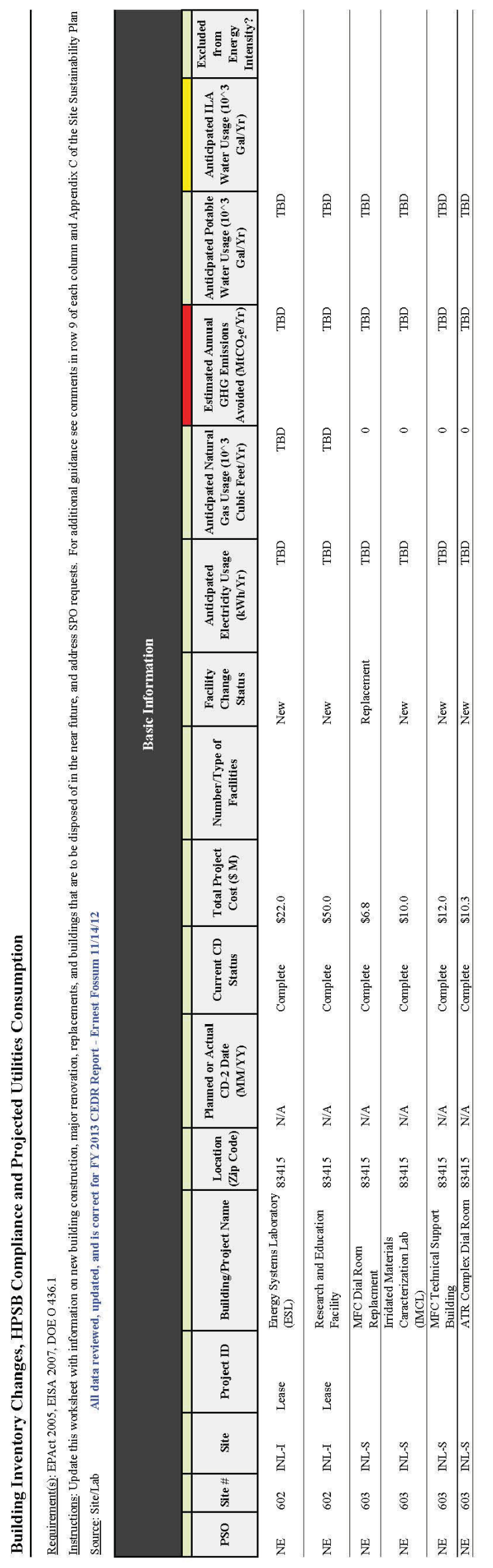




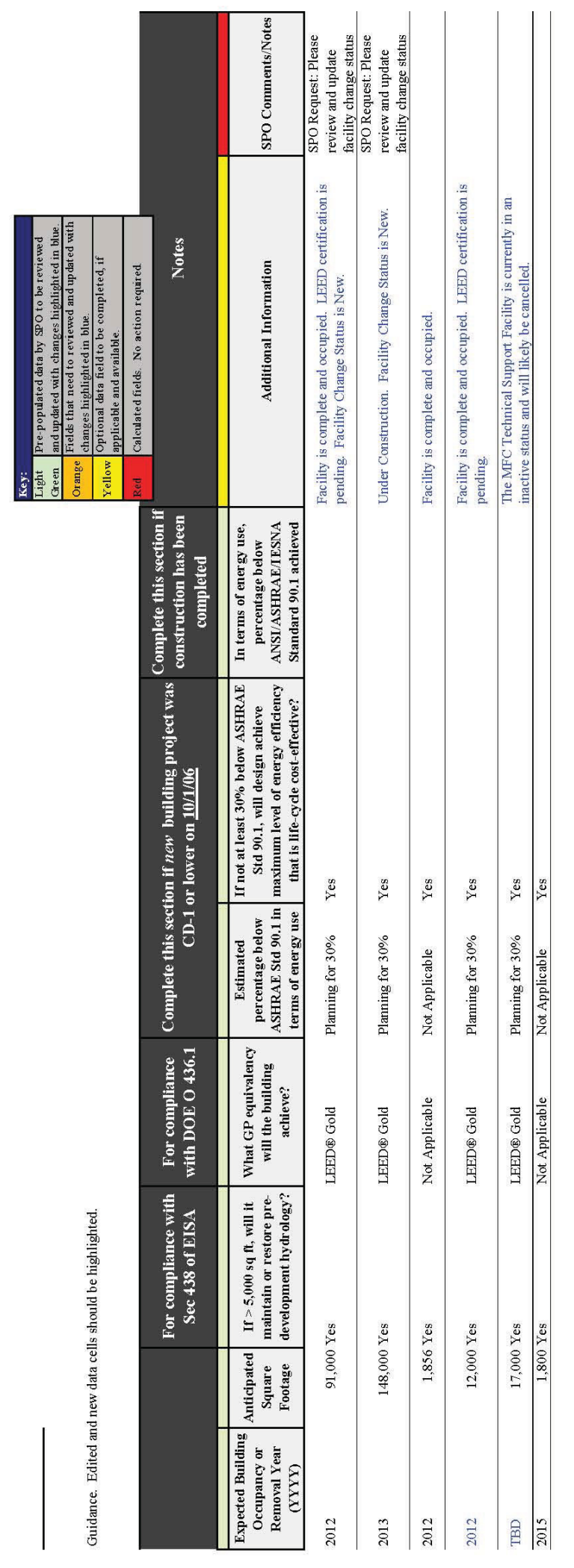

E 


\section{Source Energy Savings Credit}

\section{Requirement(s): E.O. 13123}

Instructions: Optional, complete the tables below for projects that increase site energy use but save source energy. For

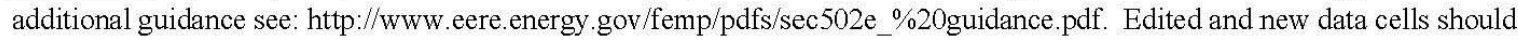
be highlighted.

Source: Site/Lab

EPACT Goal Subject Buildings

\begin{tabular}{|c|c|c|c|}
\hline \multirow{2}{*}{$\begin{array}{l}\text { Name of Project Saving Source Energy } \\
\text { in FY } 2011 \text { (insert additional rows as } \\
\text { necessary) }\end{array}$} & $\begin{array}{c}\text { Annual Site Energy } \\
\text { Increase with the Project }\end{array}$ & $\begin{array}{l}\text { Annual Source Energy } \\
\text { Saved with the Project }\end{array}$ & $\begin{array}{l}\text { Adjustment to Annual } \\
\text { Site Energy }\end{array}$ \\
\hline & $\left(10^{\wedge} 6 \mathrm{BTU} / \mathrm{Yr}\right)$ & $\left(10^{\wedge} 6 \mathrm{BTU} / \mathrm{Yr}\right)$ & $\left(10^{\wedge} 6 \mathrm{BTU} / \mathrm{Yr}\right)$ \\
\hline Project No. 1 & 0.0 & 0.0 & 0.0 \\
\hline Project No. 2 & 0.0 & 0.0 & 0.0 \\
\hline Project No. 3 & 0.0 & 0.0 & 0.0 \\
\hline Totals & 0.0 & 0.0 & 0.0 \\
\hline
\end{tabular}

EPACT Excluded Buildings

\begin{tabular}{|c|c|c|c|}
\hline \multirow{2}{*}{$\begin{array}{l}\text { Name of Project Saving Source Energy } \\
\text { in FY } 2011 \text { (insert additional rows as } \\
\text { necessary) }\end{array}$} & $\begin{array}{c}\text { Annual Site Energy } \\
\text { Increase with the Project }\end{array}$ & $\begin{array}{l}\text { Annual Source Energy } \\
\text { Saved with the Project }\end{array}$ & $\begin{array}{l}\text { Adjustment to Annual } \\
\text { Site Energy }\end{array}$ \\
\hline & $\left(10^{\wedge} 6 \mathrm{BTU} / \mathrm{Yr}\right)$ & $\left(10^{\wedge} 6 \mathrm{BTU} / \mathrm{Yr}\right)$ & $\left(10^{\wedge} 6 \mathrm{BTU} / \mathrm{Yr}\right)$ \\
\hline Project No. 1 & 0.0 & 0.0 & 0.0 \\
\hline Project No. 2 & 0.0 & 0.0 & $\overline{0.0}$ \\
\hline Project No. 3 & 0.0 & 0.0 & 0.0 \\
\hline Totals & $\overline{0.0}$ & $\overline{0.0}$ & 0.0 \\
\hline
\end{tabular}




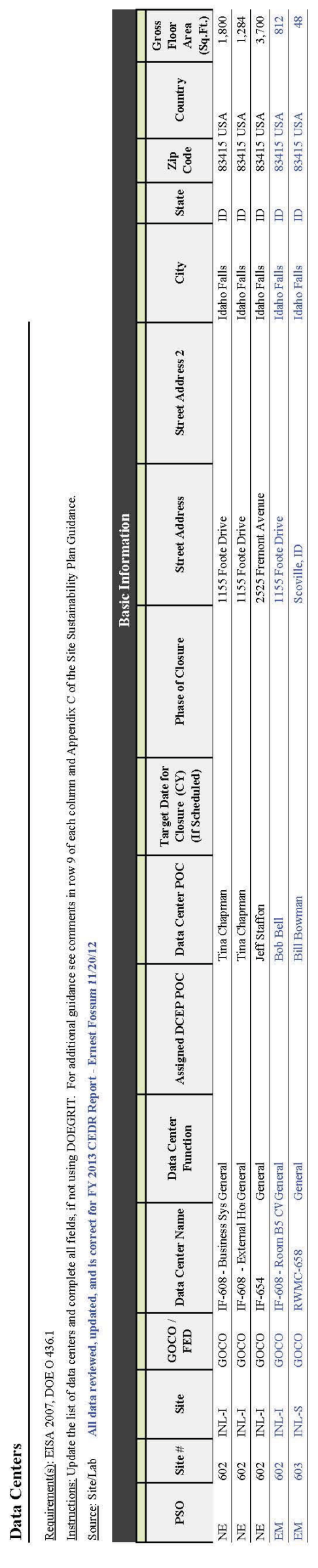

9 


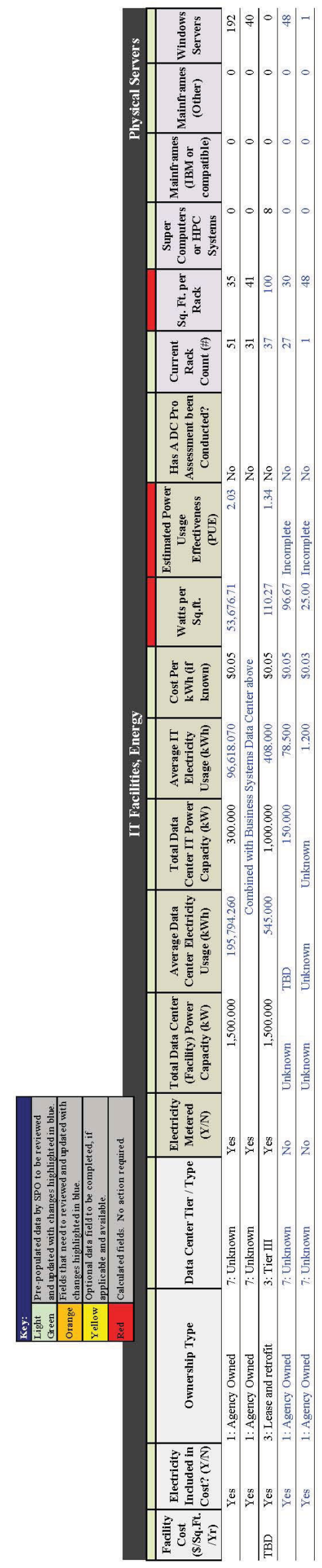




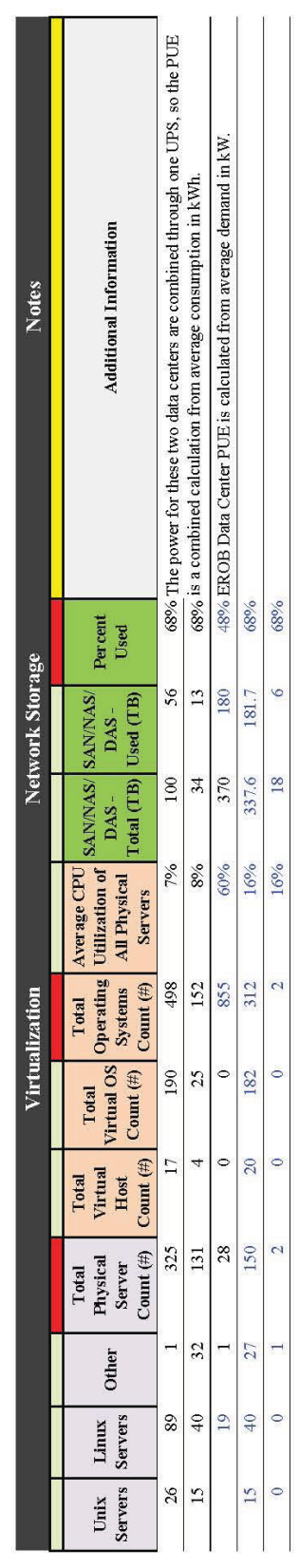




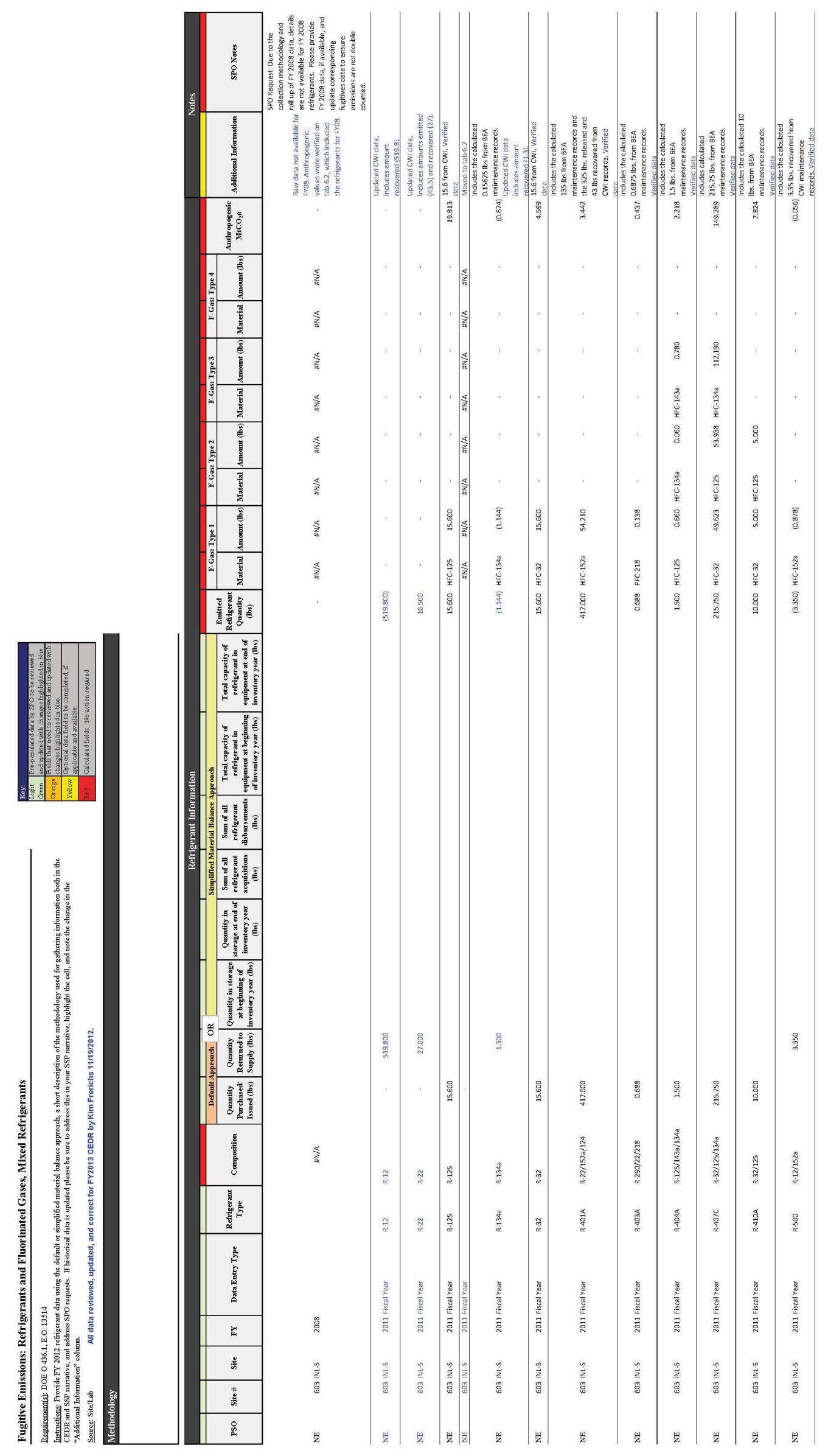




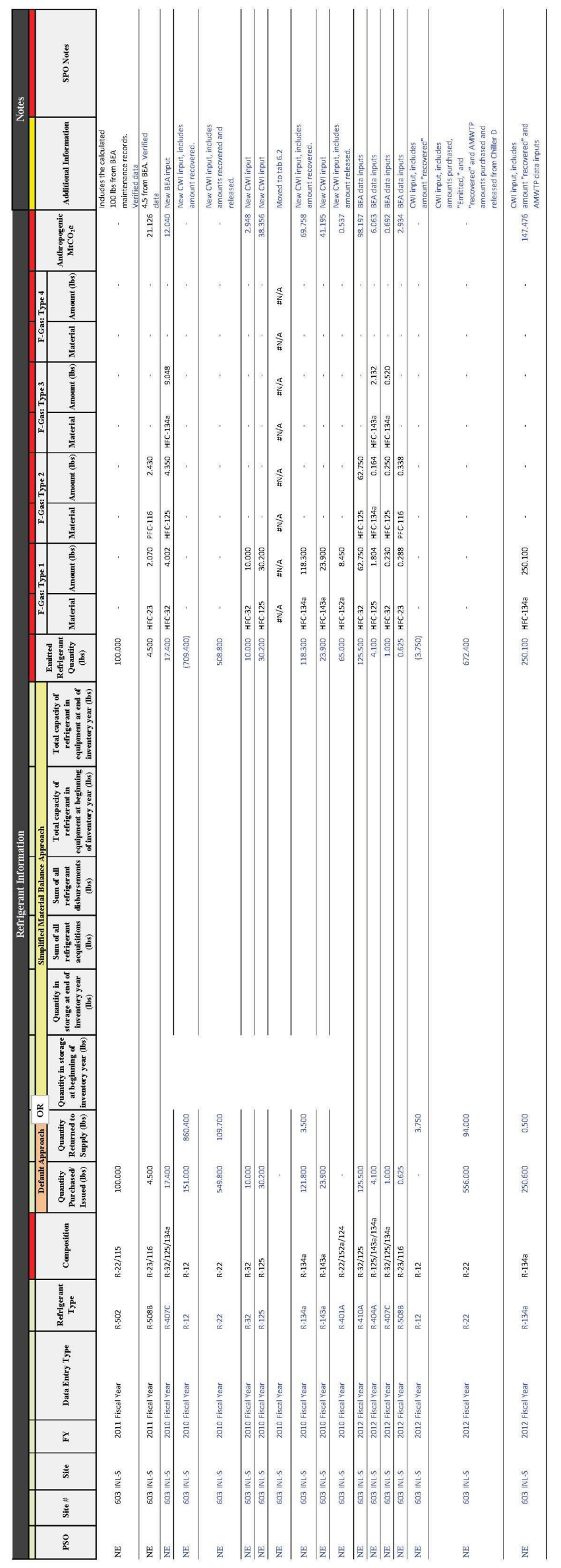




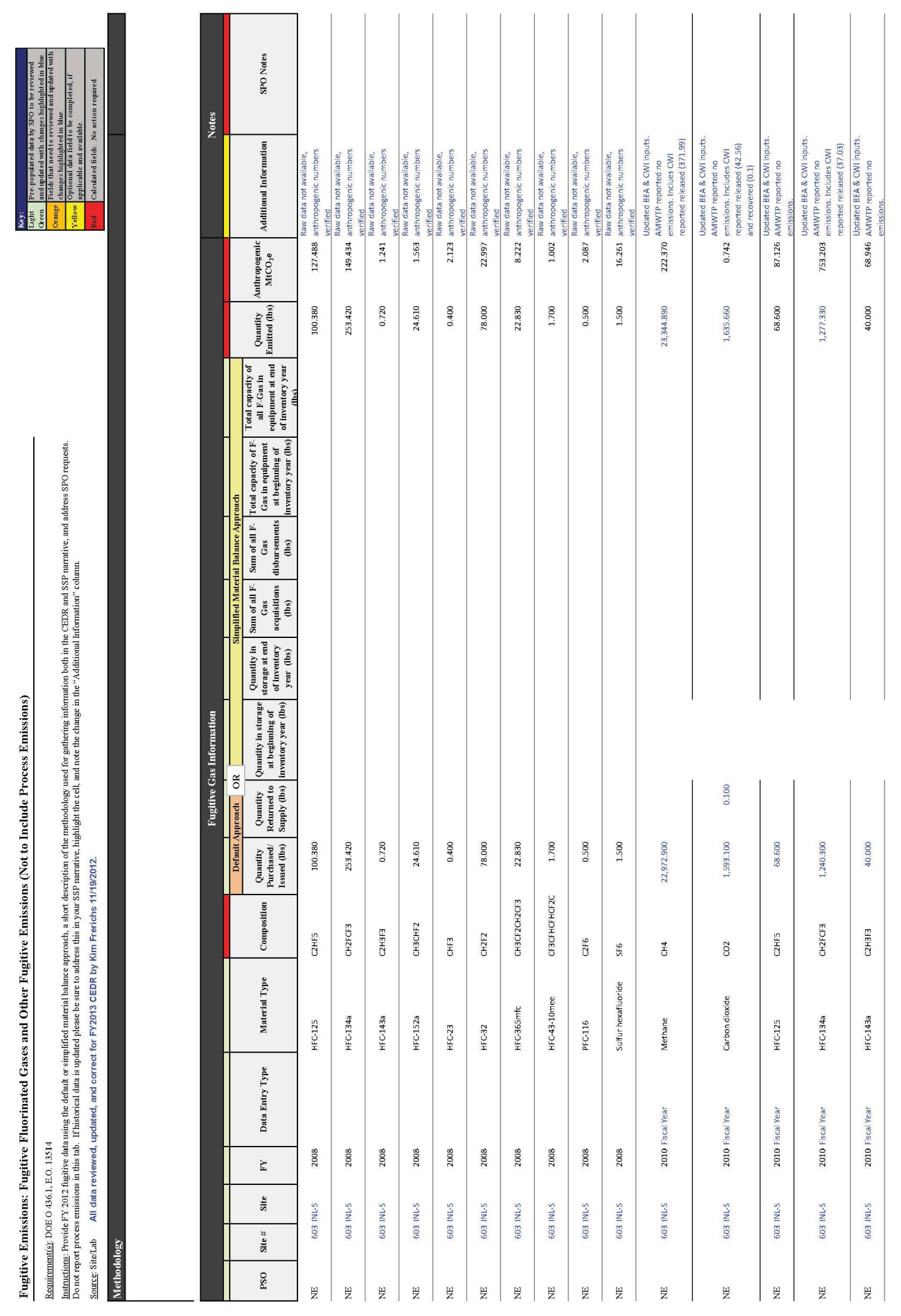




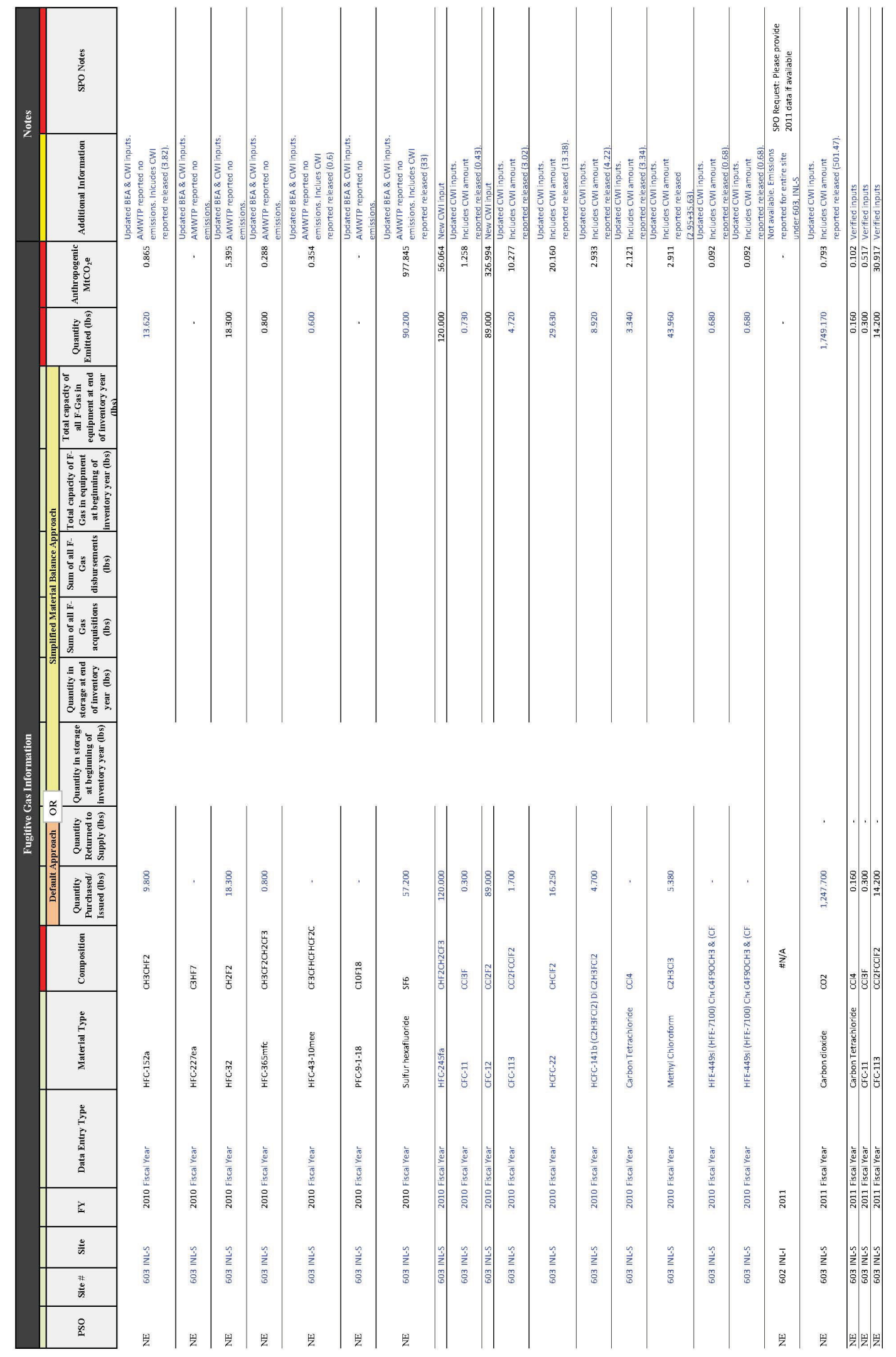




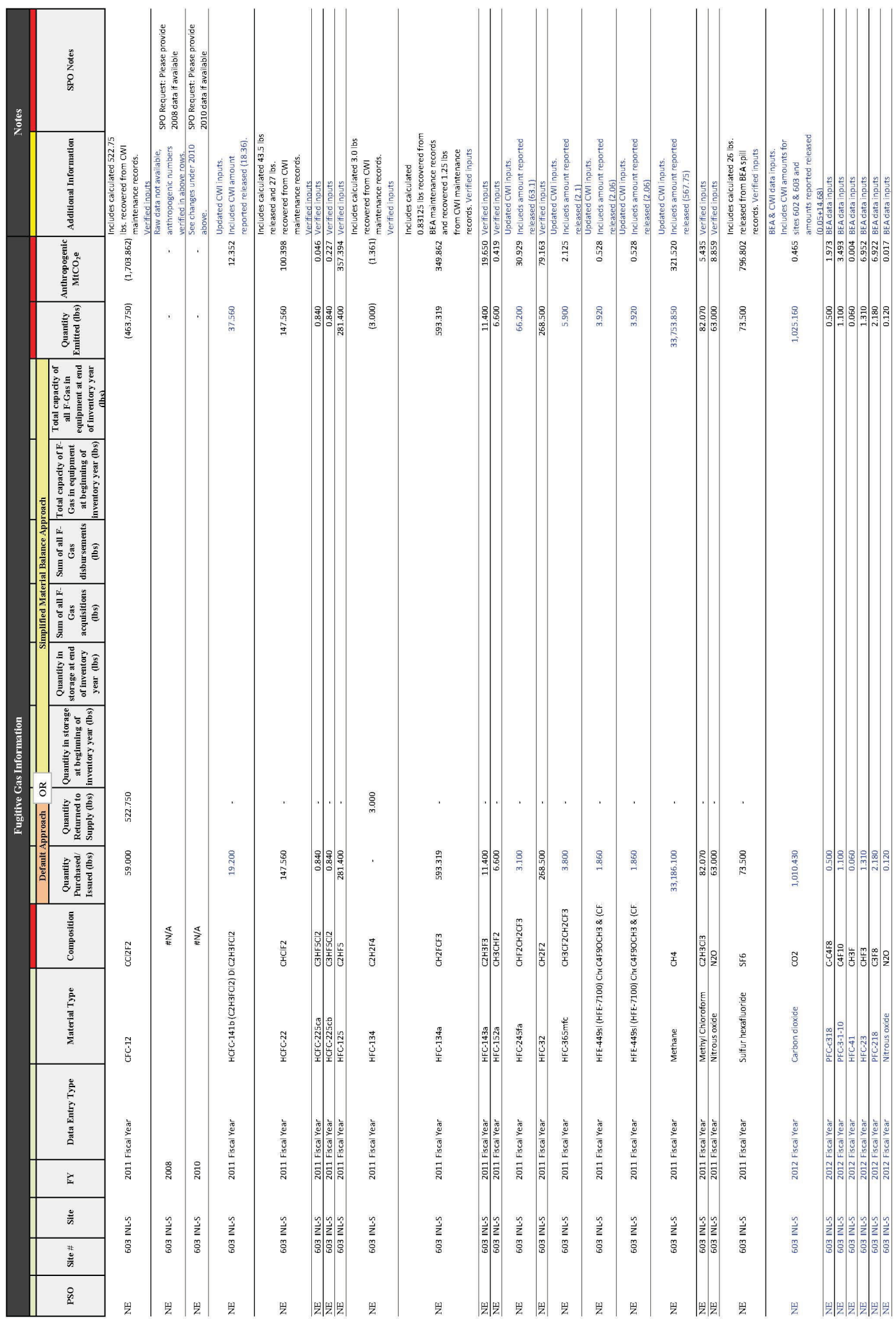




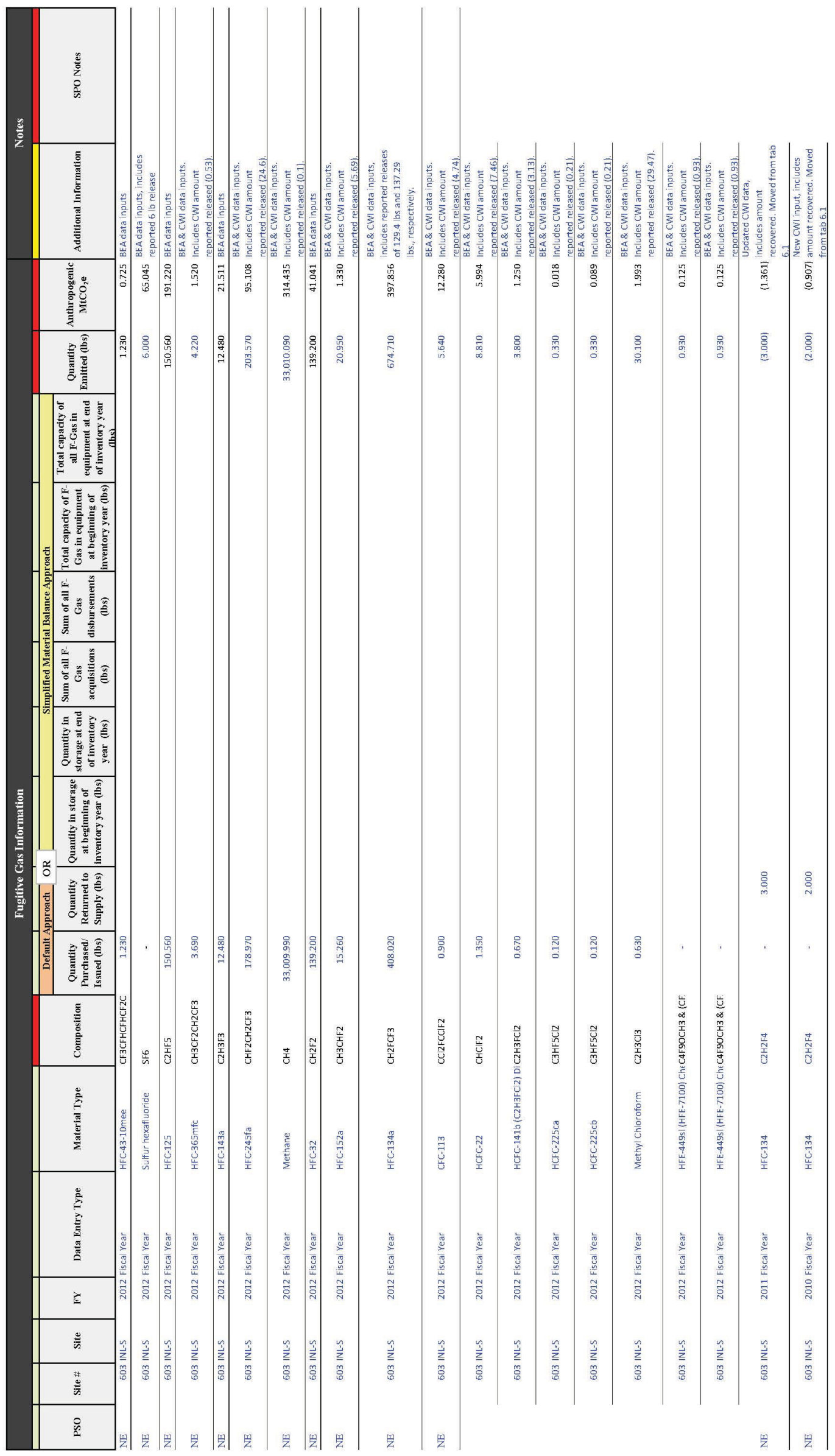




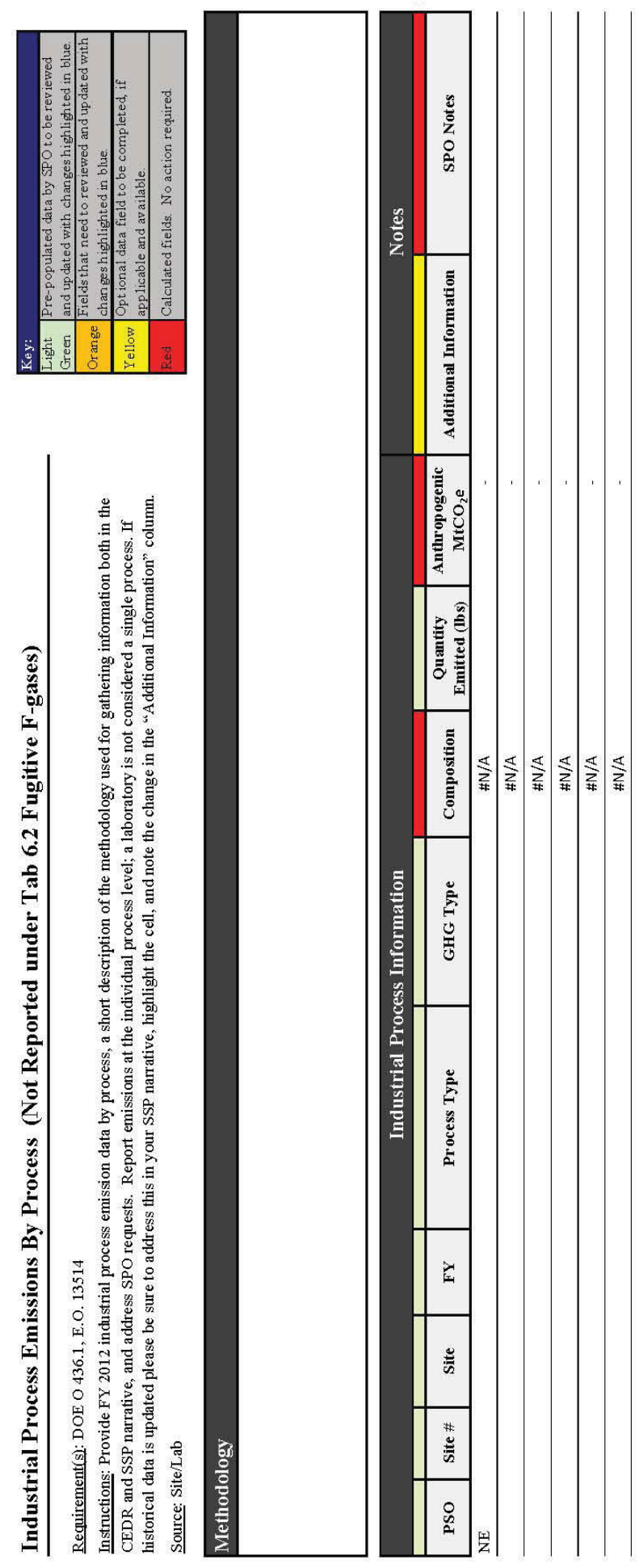

$\infty$ 


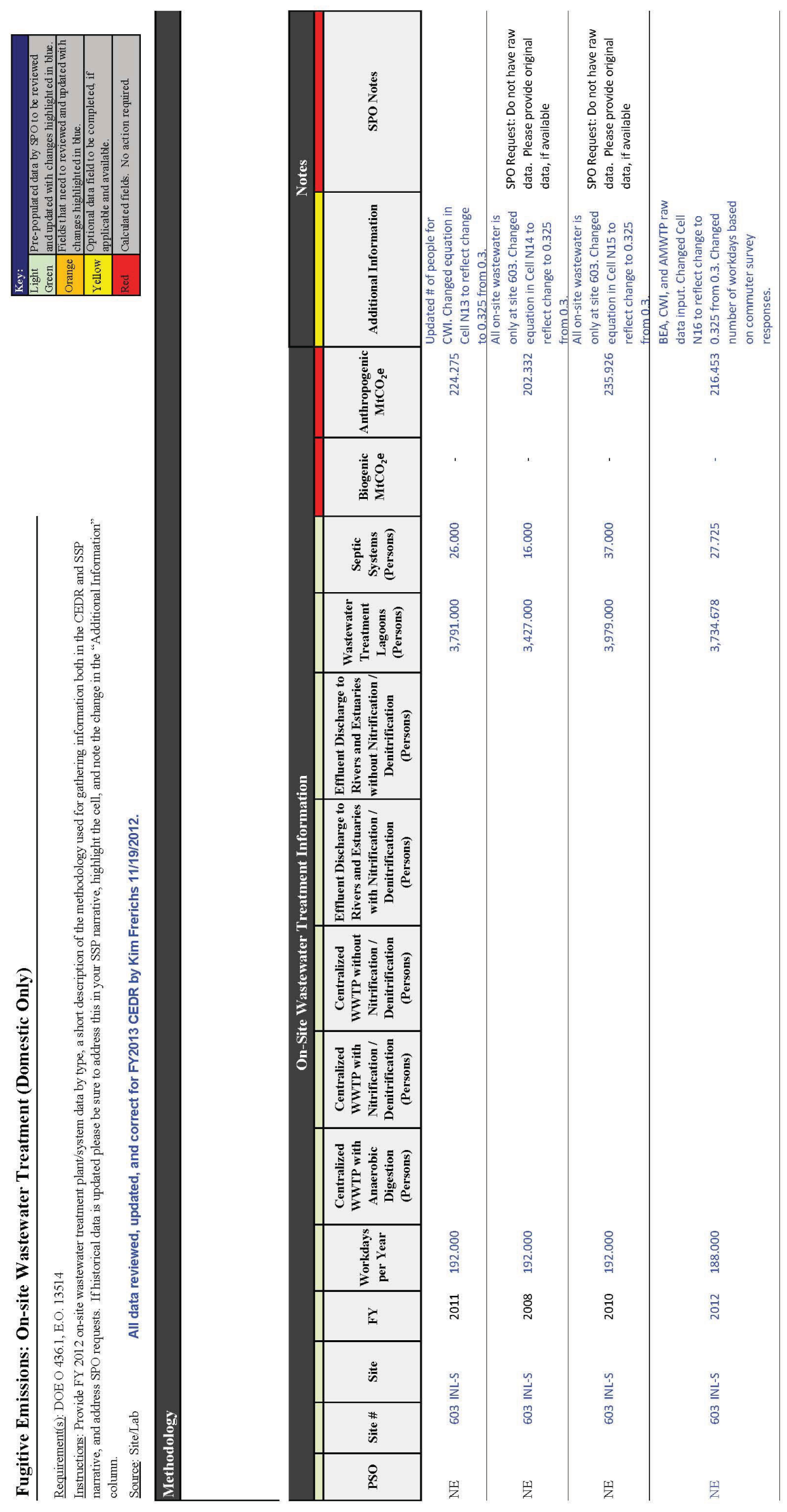



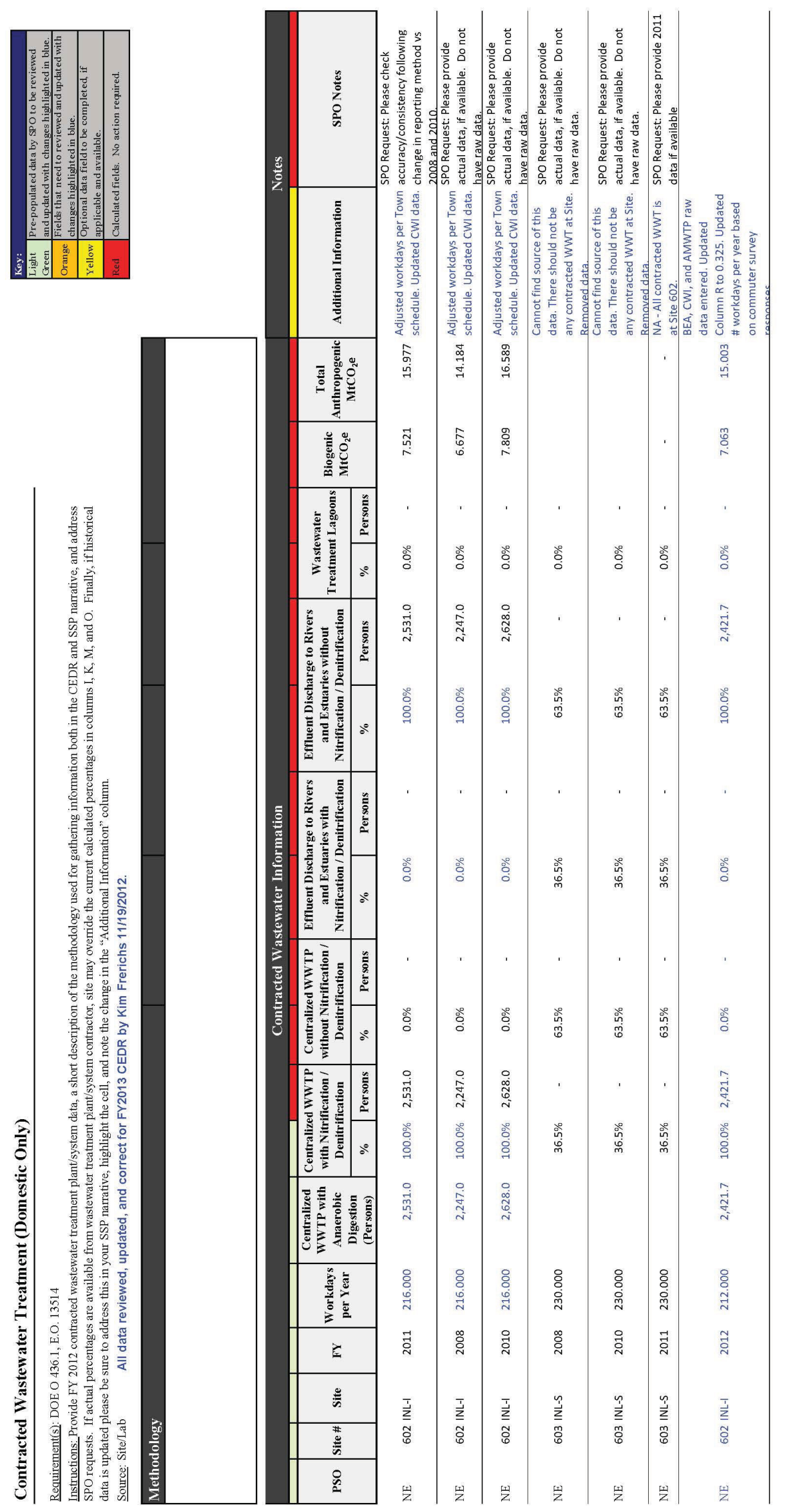


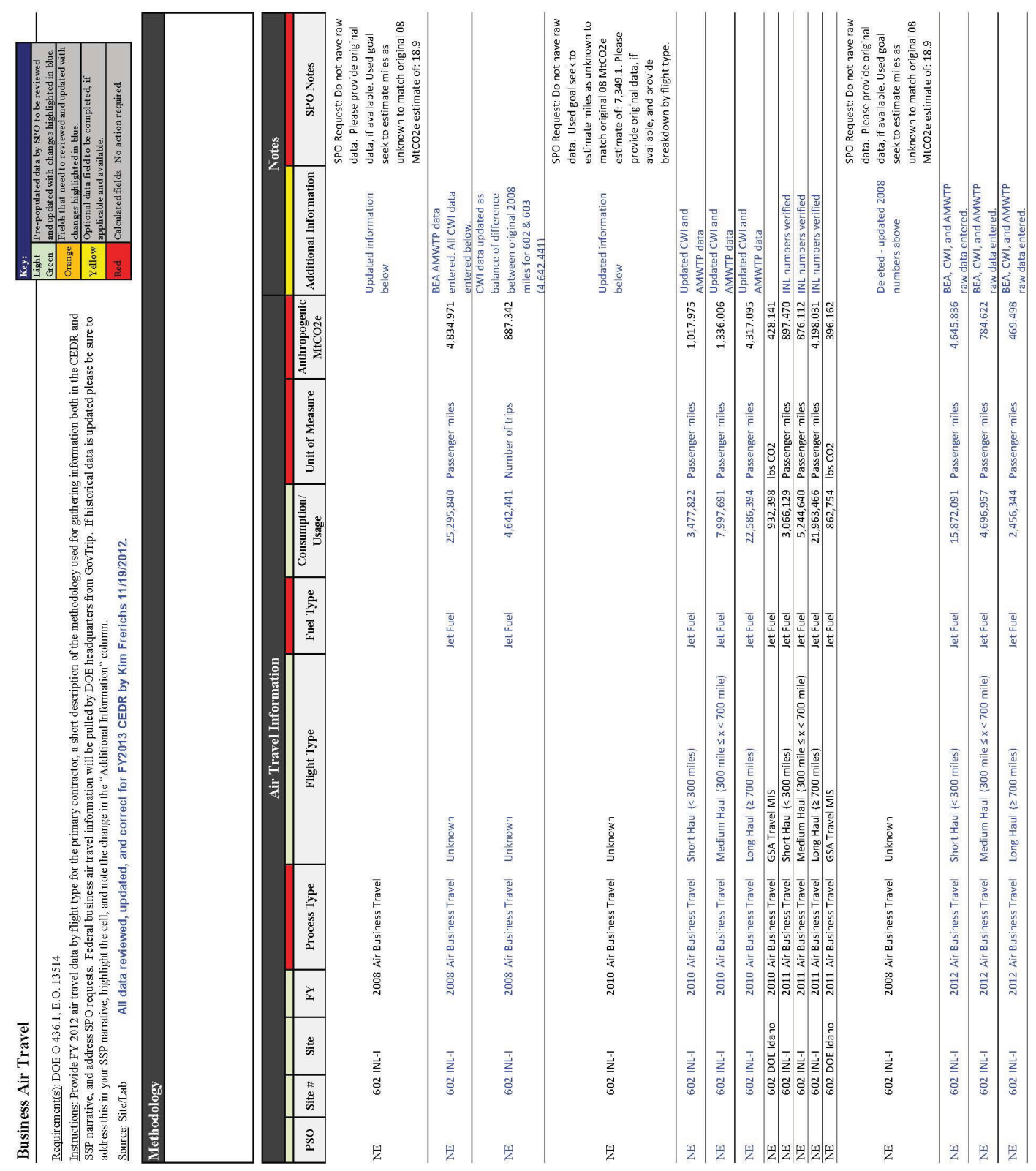

$a$ 


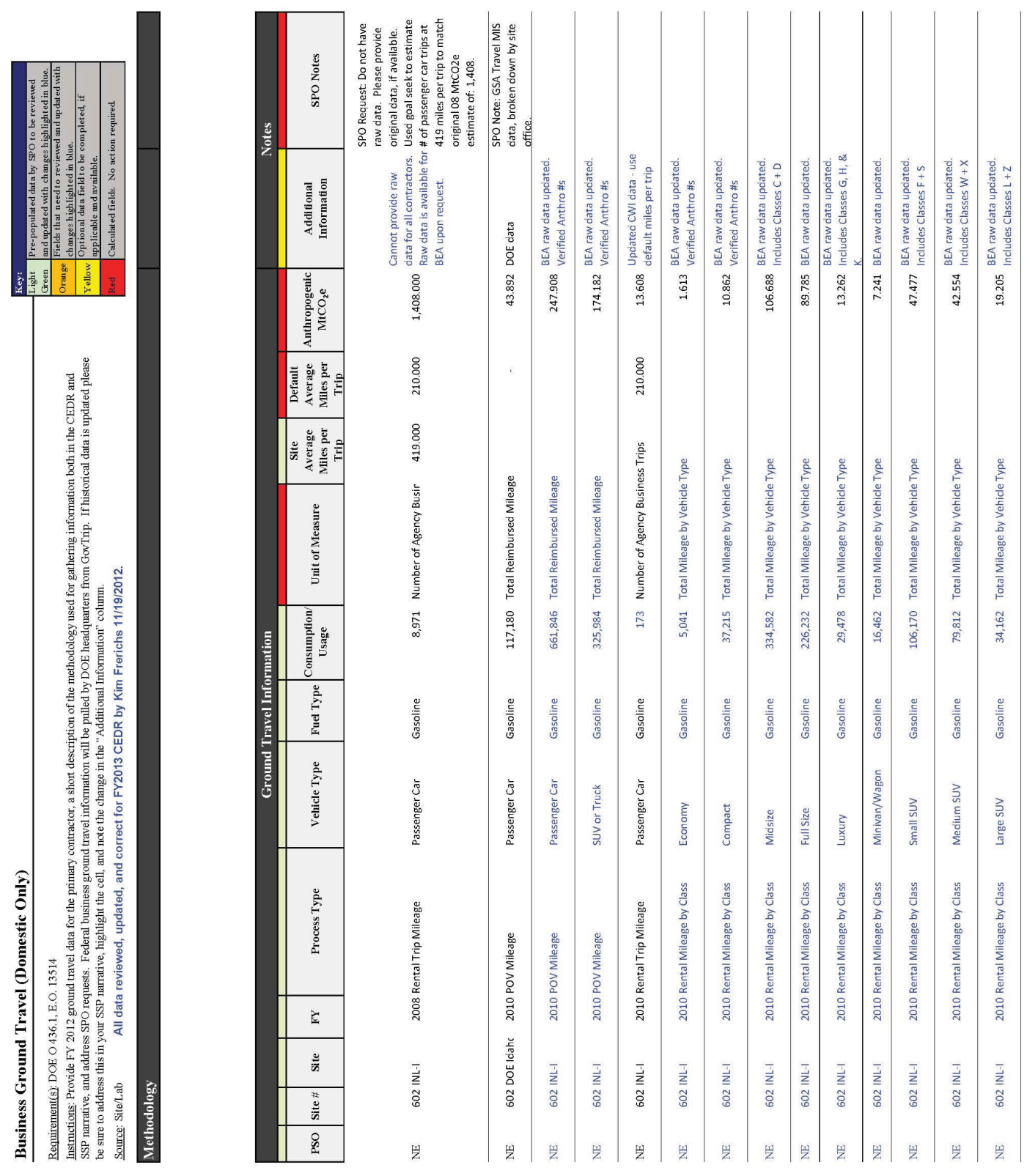




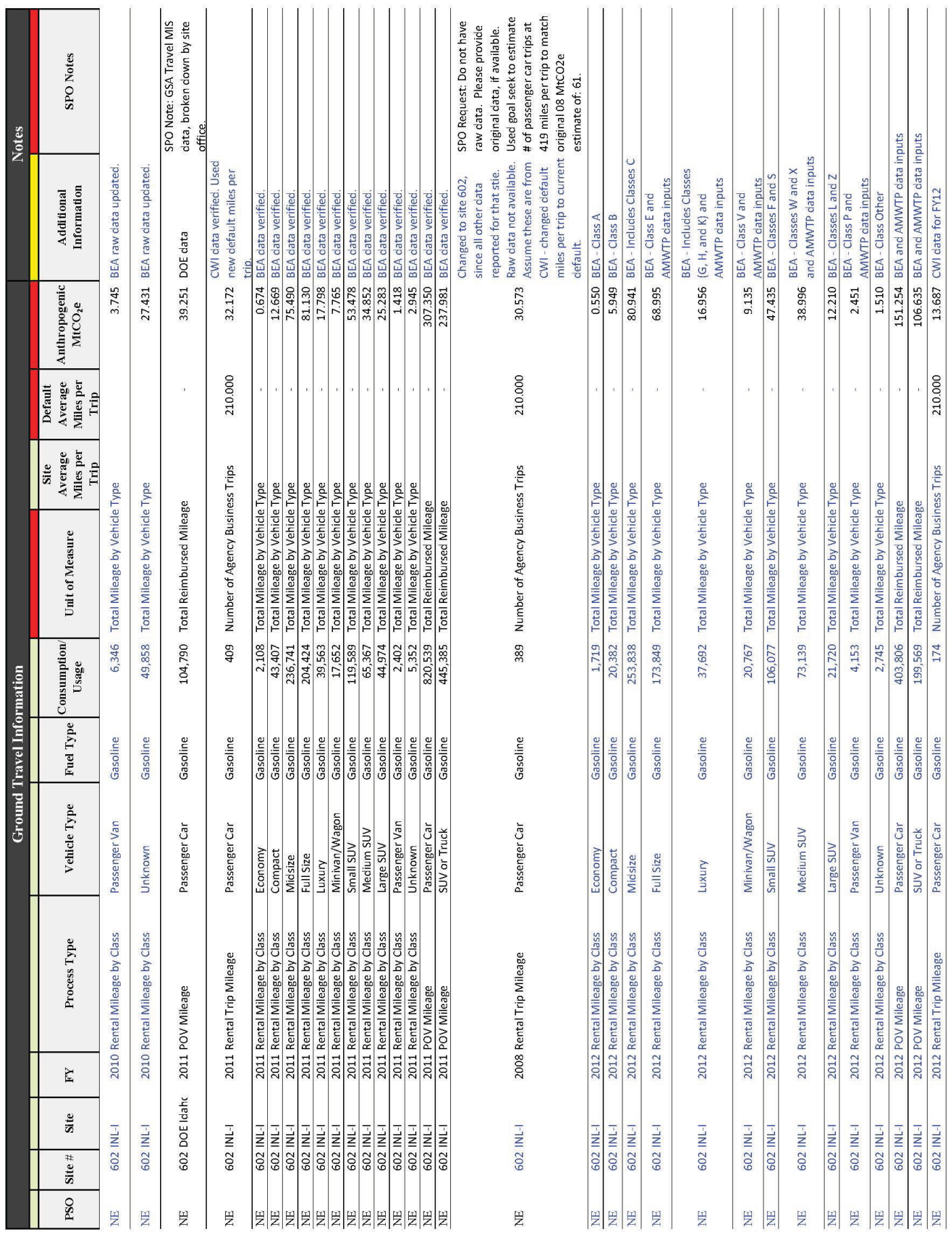




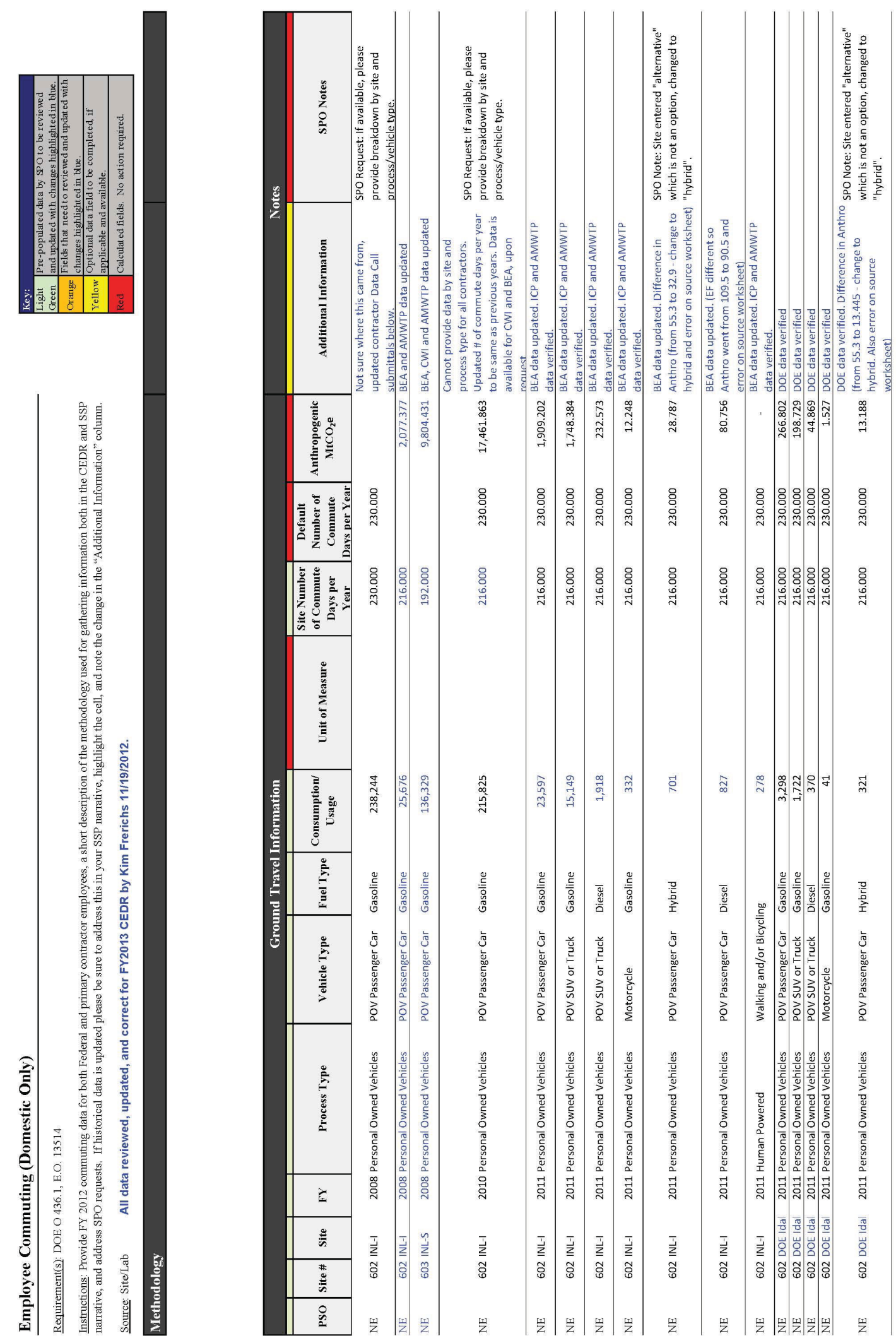



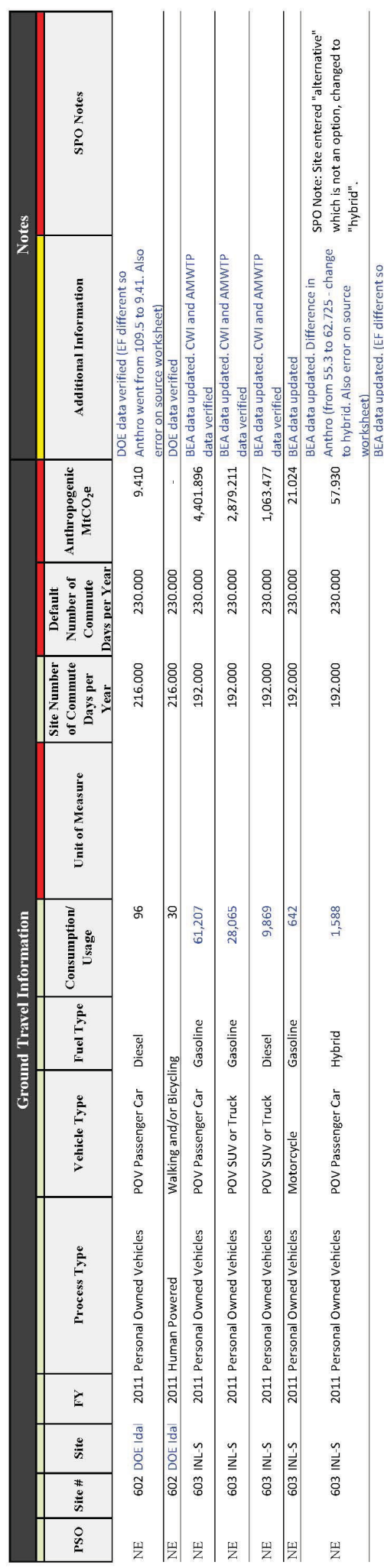

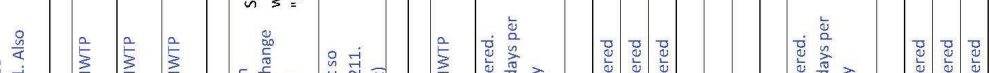

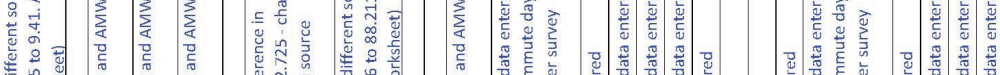

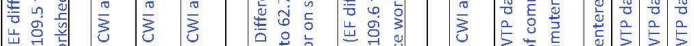

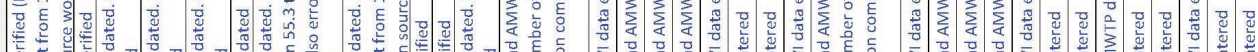

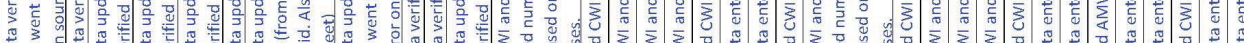

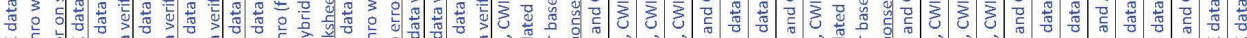

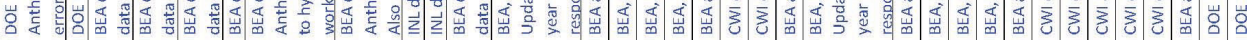

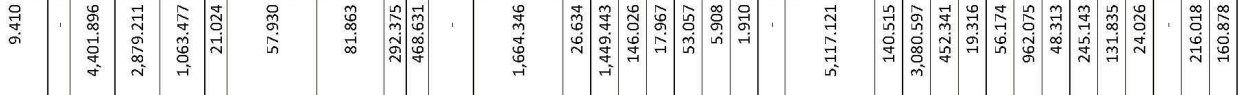

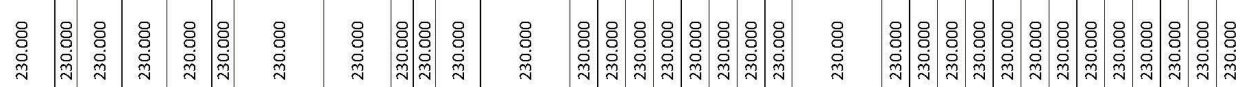

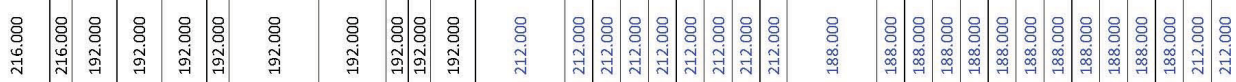

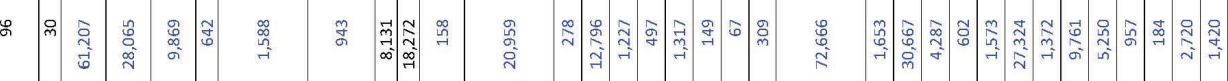

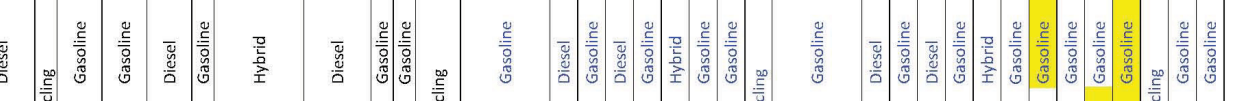

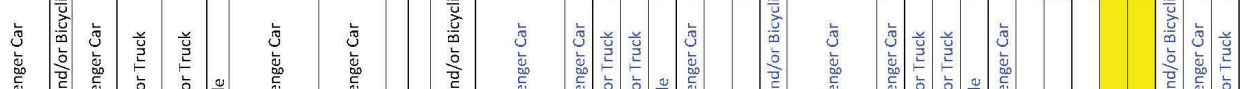

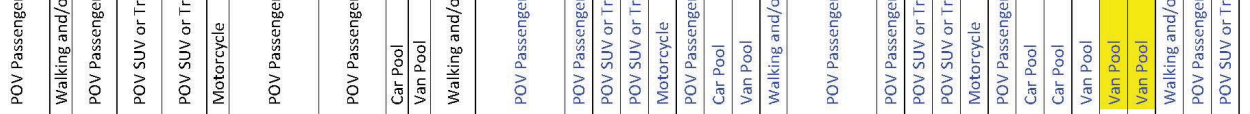

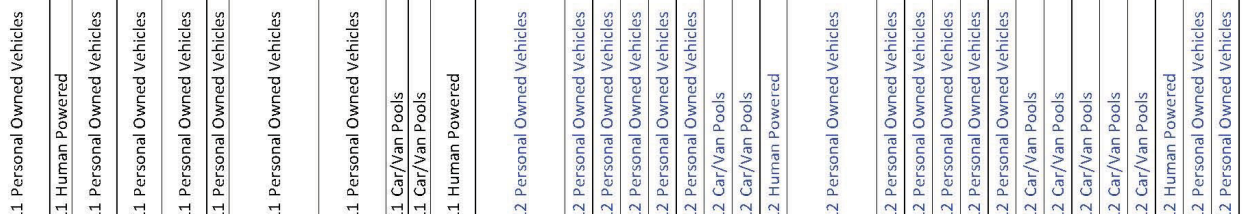

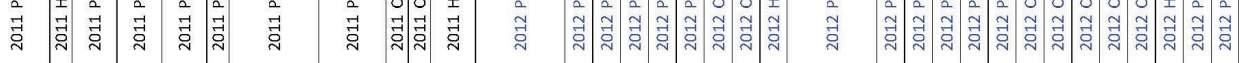

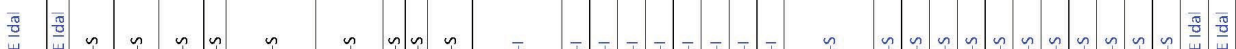

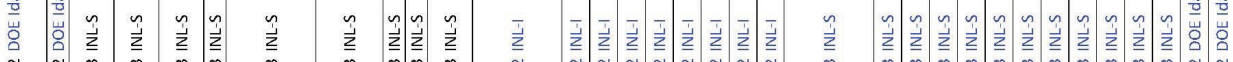

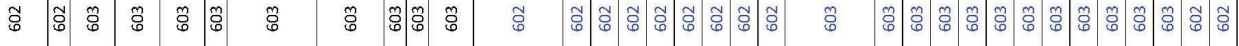

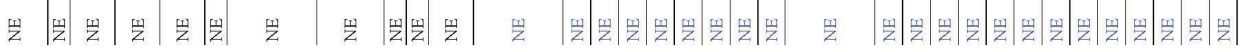




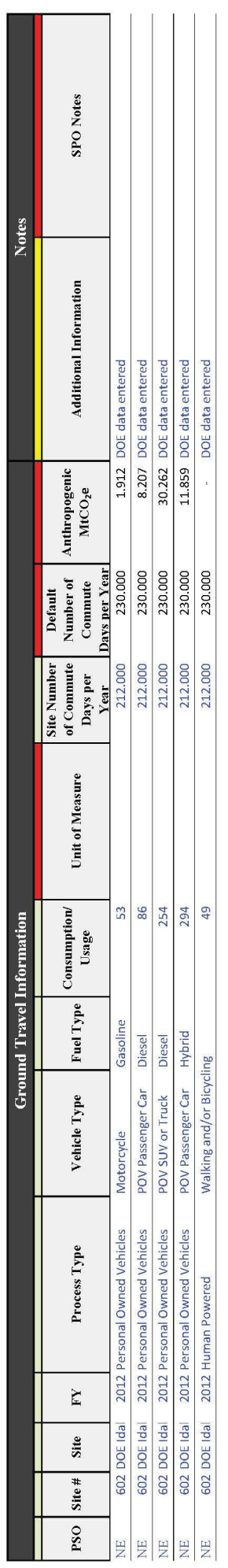




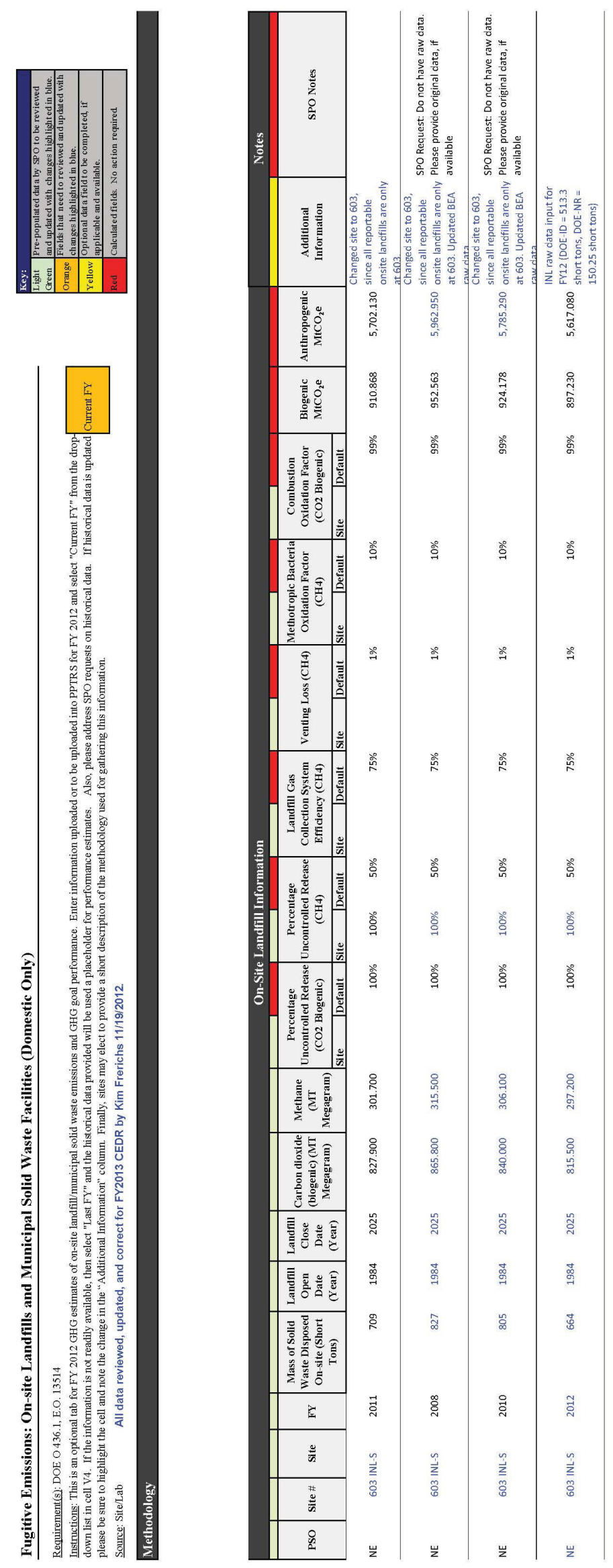




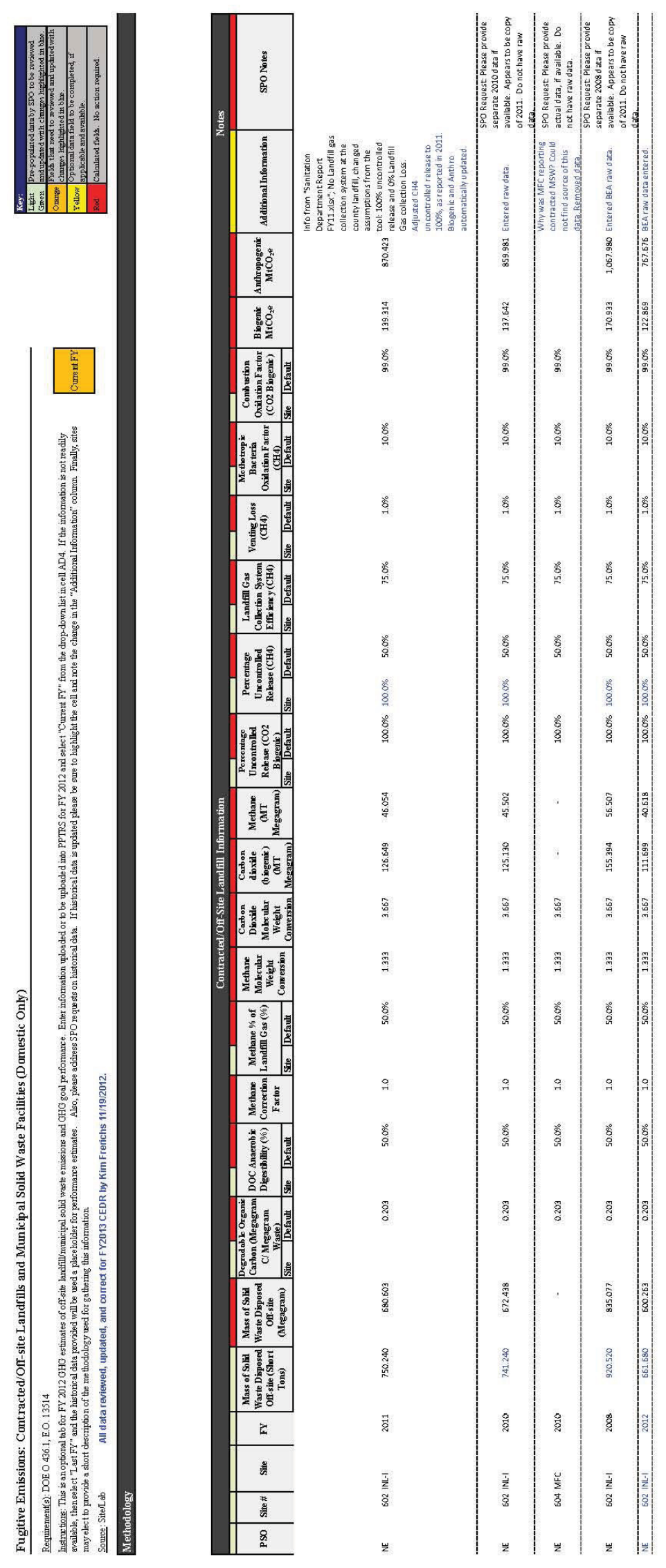




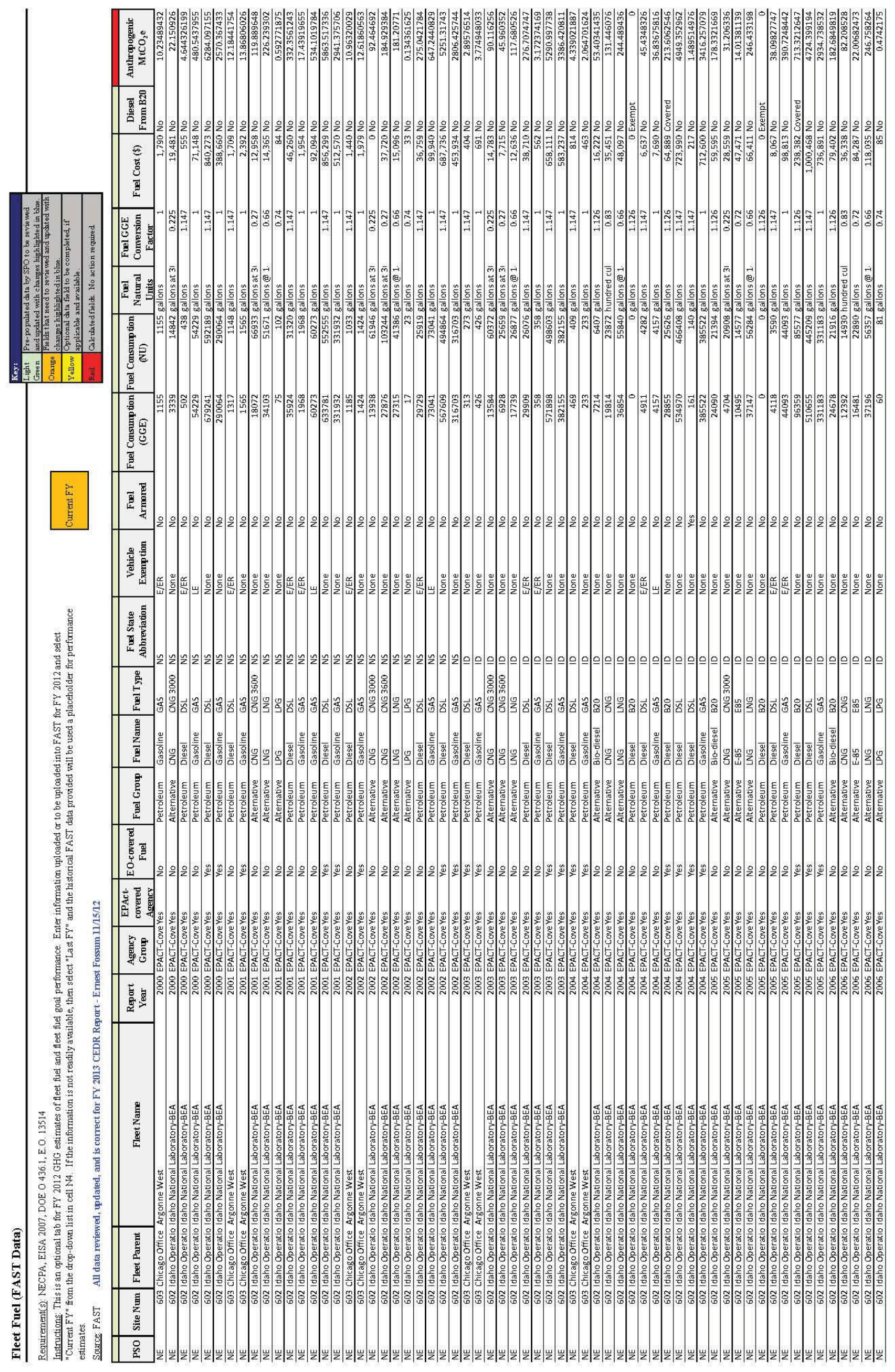




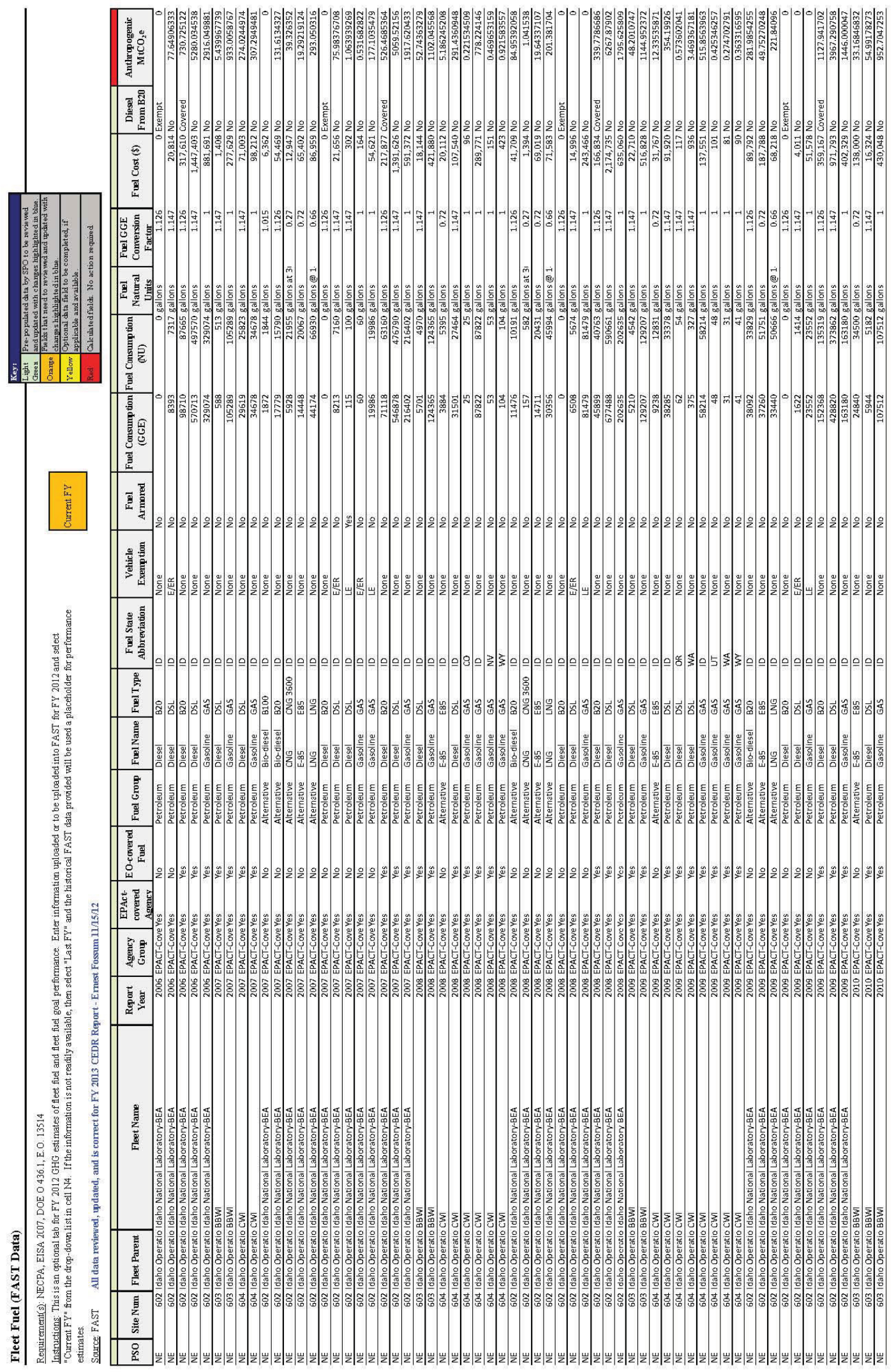




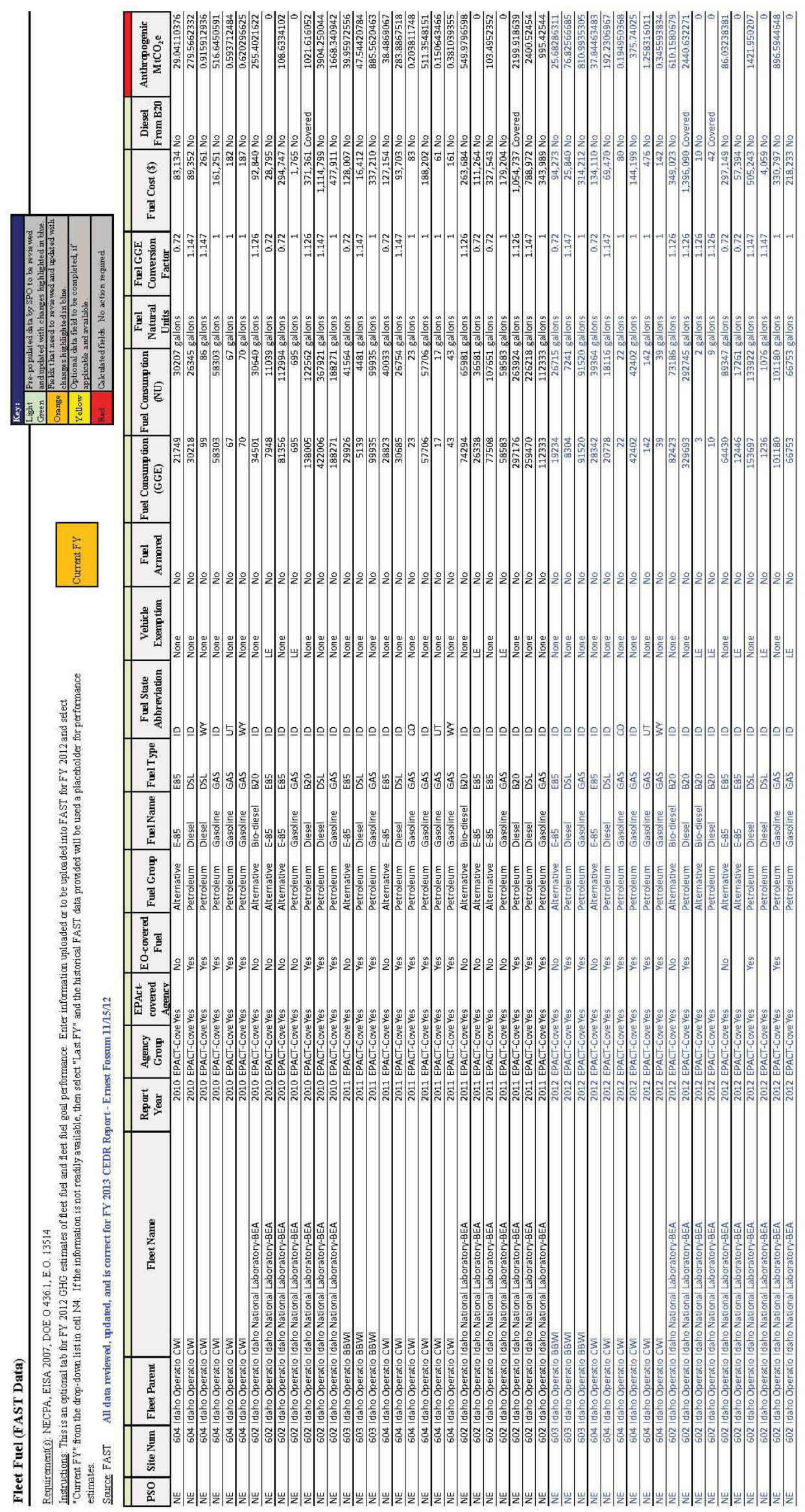




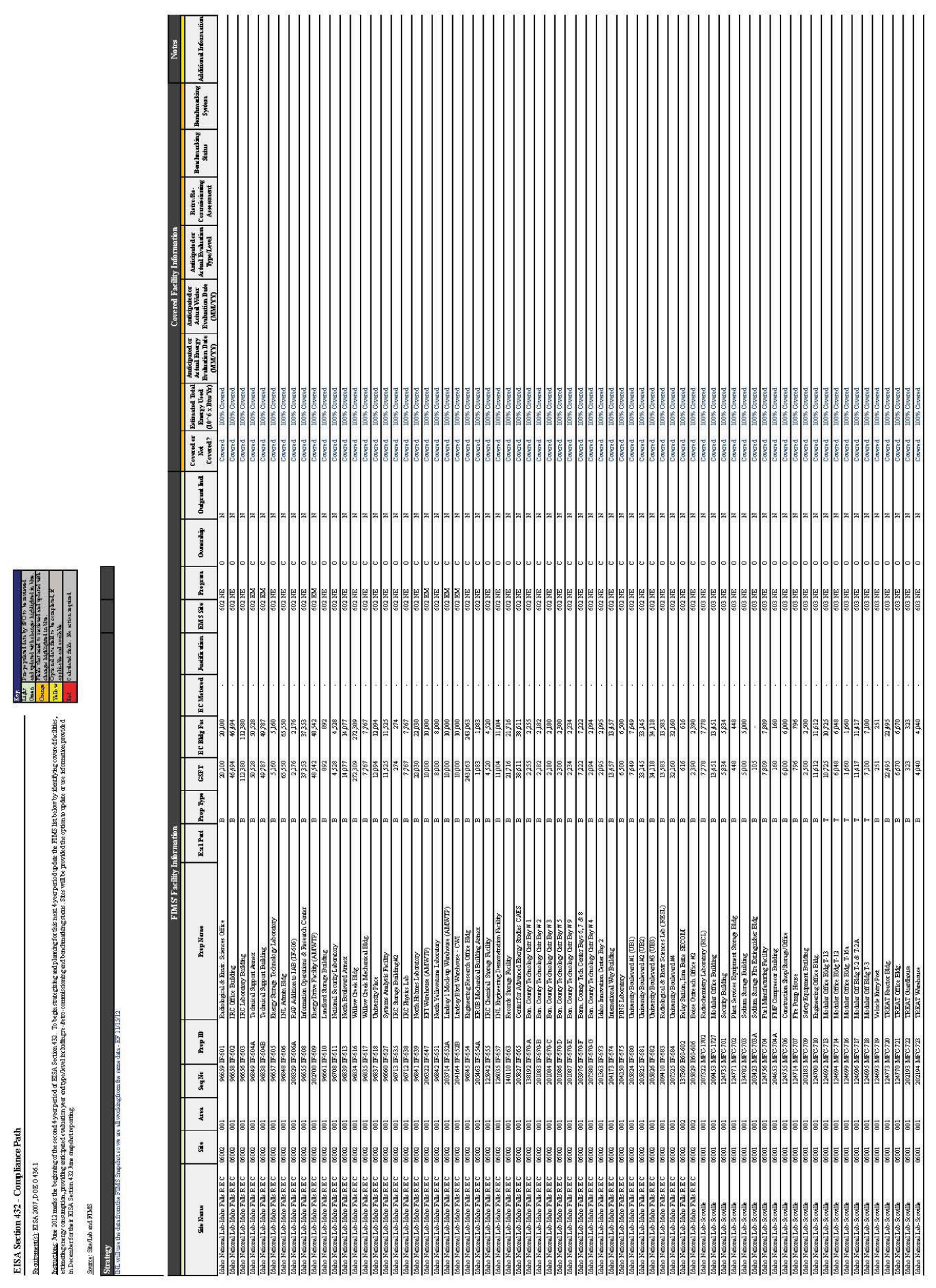




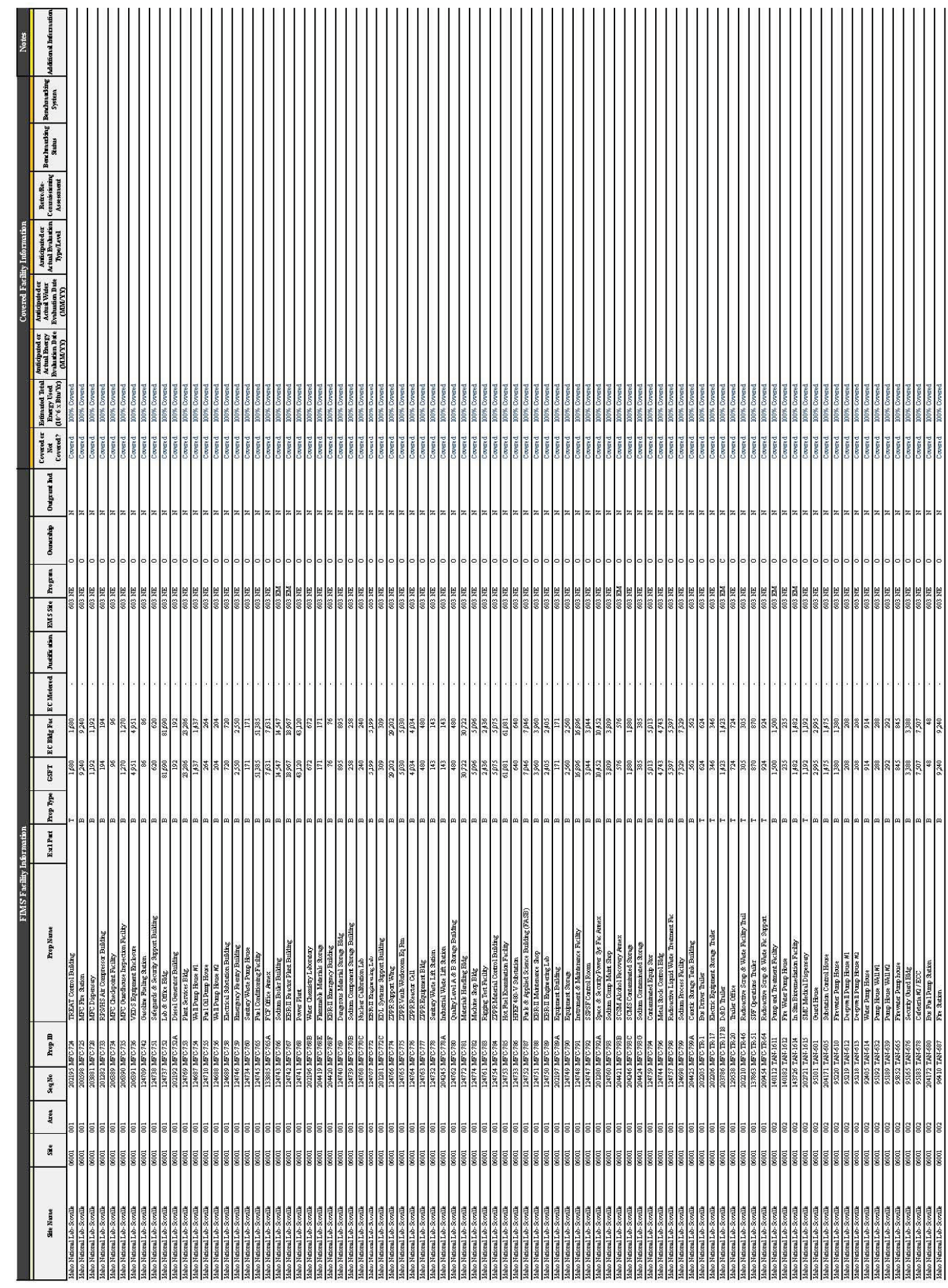




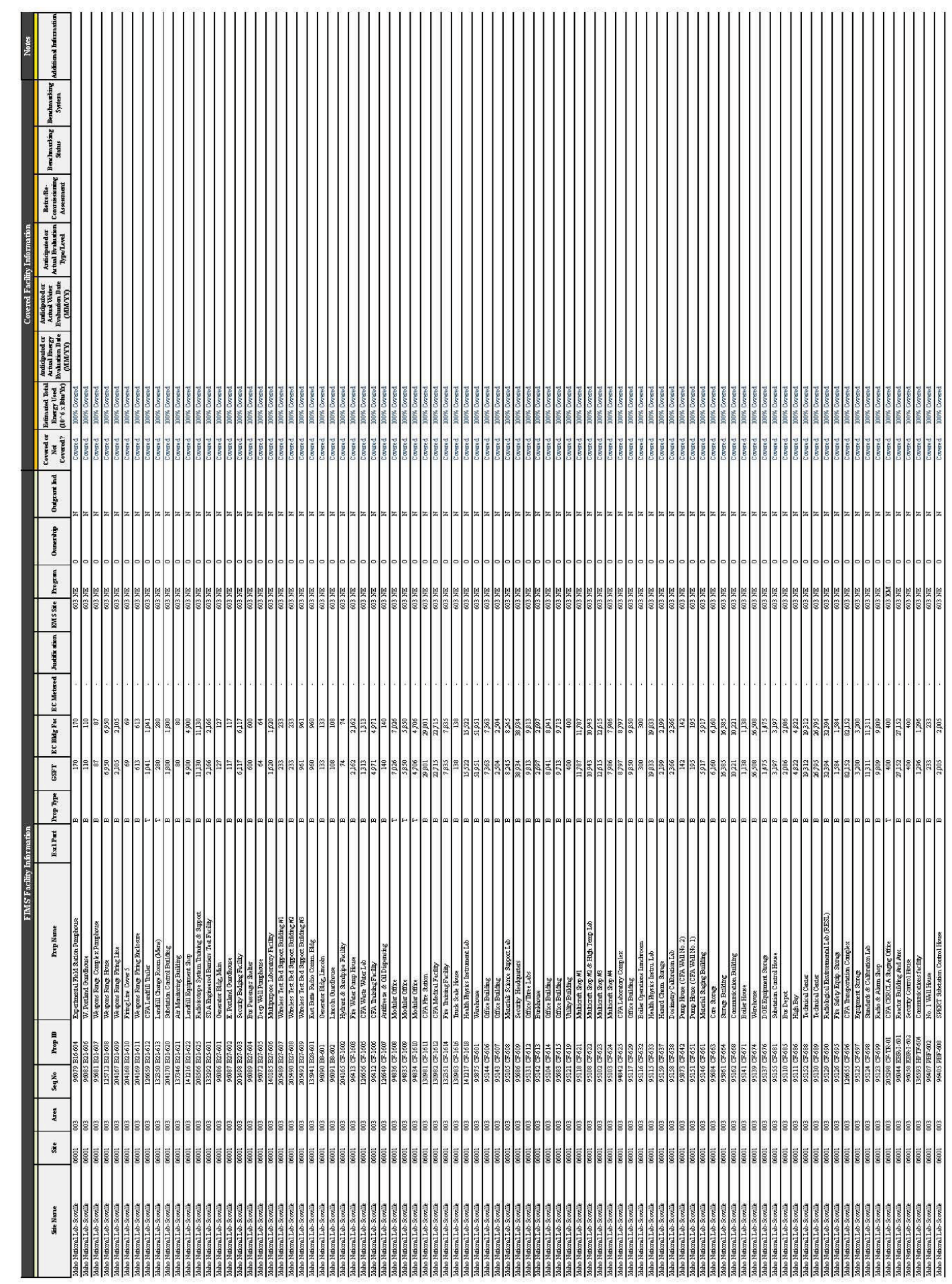




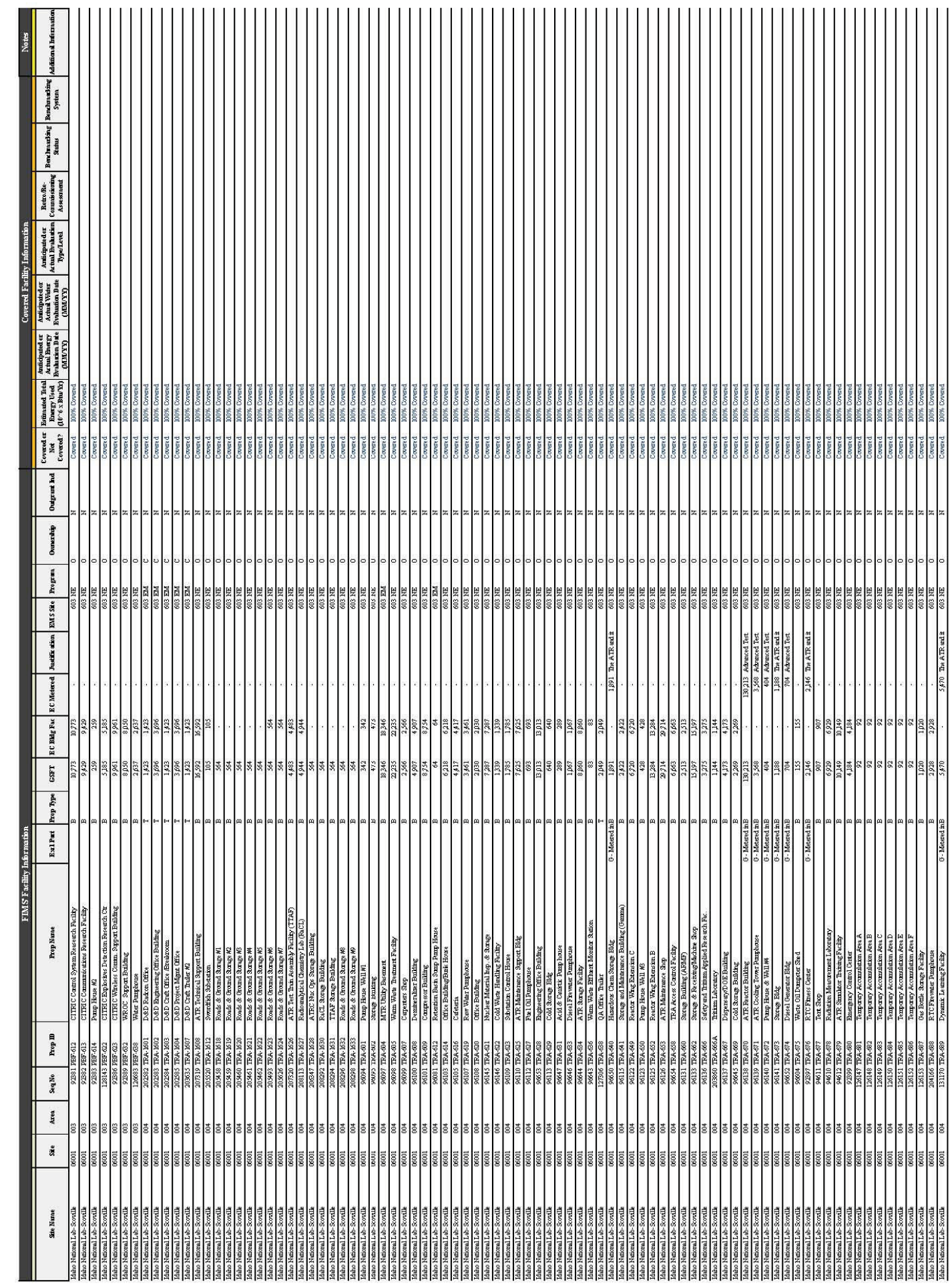




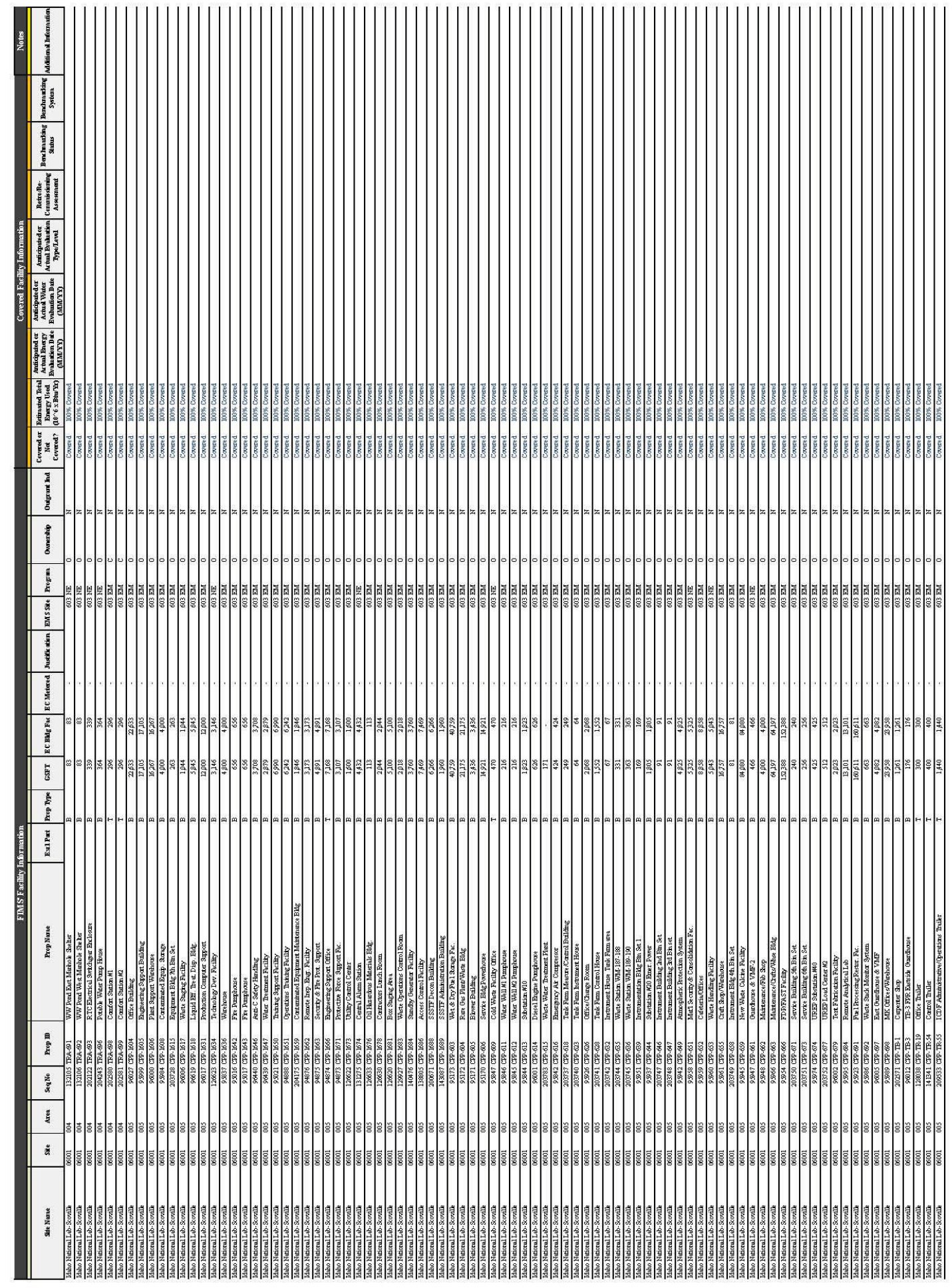




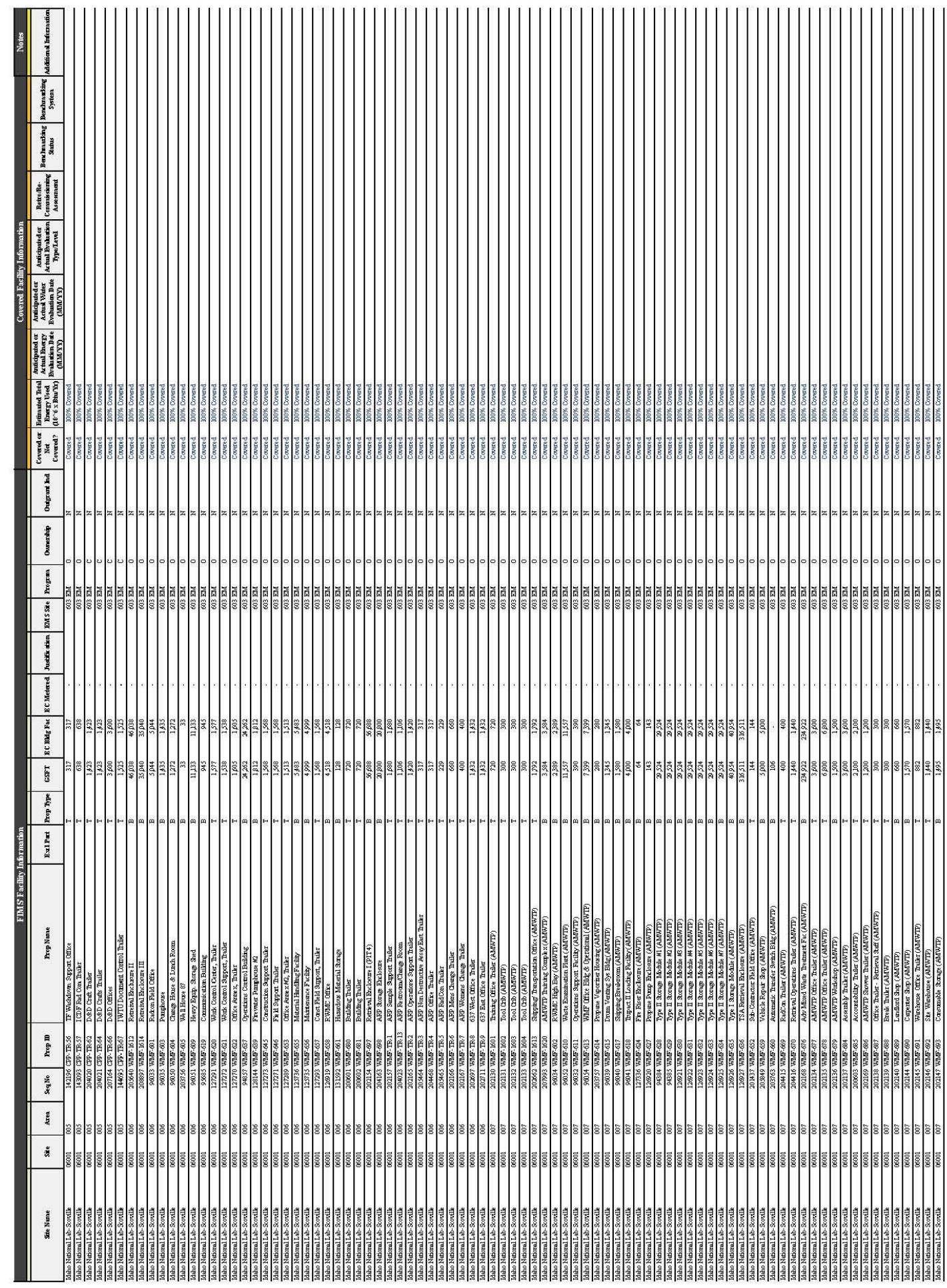




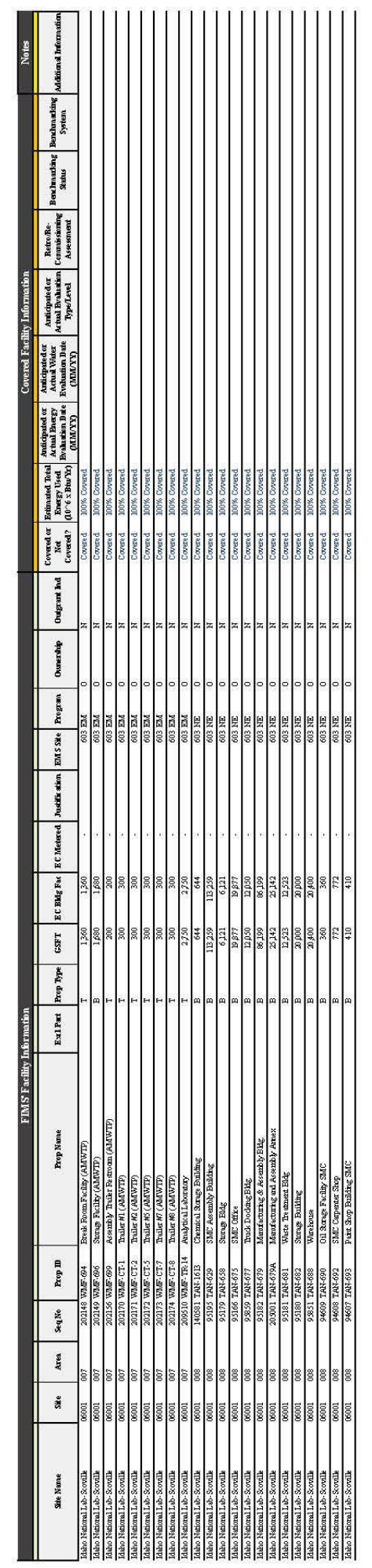

